\title{
Local management and landscape context effects on bee pollination, ant seed predation, and yield in Indonesian homegardens
}

\author{
Dissertation \\ zur Erlangung des Doktorgrades \\ der Fakultät für Agrarwissenschaften \\ der Georg-August-Universität Göttingen
}

vorgelegt von

Iris Cordula Motzke

geboren in Böblingen

Göttingen, März 2014 
D 7

1. Referentin/Referent: Prof. Dr. Teja Tscharntke

2. Korreferentin/Korreferent: Prof. Dr. Alexandra-Maria Klein

Tag der mündlichen Prüfung: 15. Mai 2014 


\section{Table of Contents}

Summary 1

Chapter 1

General Introduction

Tropical agriculture, yield gaps and ecosystem services . . . . . . . . . . . . . 5

Study region and experimental design $\ldots \ldots \ldots \ldots$

Research aims . . . . . . . . . . . . . . . . . . 11

General conclusion . . . . . . . . . . . . . . . . 12

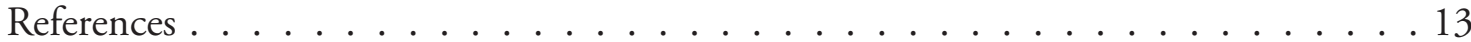

Chapter 2

Pollination mitigates cucumber yield gaps more than pesticide and fertilizer use in $\begin{array}{ll}\text { tropical smallholder gardens } & 18\end{array}$

Introduction . . . . . . . . . . . . . . . . . . . 20

Methods . . . . . . . . . . . . . . . . . . . . . . . 21

Results. . . . . . . . . . . . . . . . . . . . 24

Discussion . . . . . . . . . . . . . . . . . 28

Conclusions and management recommendations . . . . . . . . . . . 31

Supporting information . . . . . . . . . . . . . . . 38

Chapter 3

Bee management on multiple spatial scales is needed to enhance crop yield in tropical $\begin{array}{ll}\text { homegardens } & 47\end{array}$

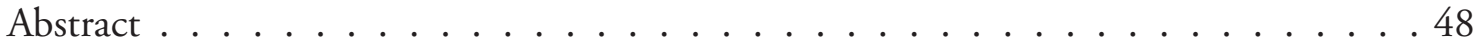

Introduction . . . . . . . . . . . . . . . . . . . . 49

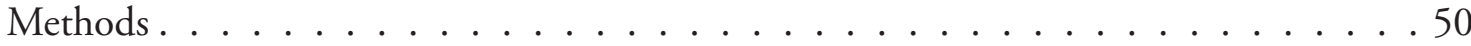

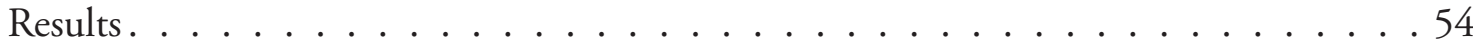

Discussion . . . . . . . . . . . . . . . . . . 57

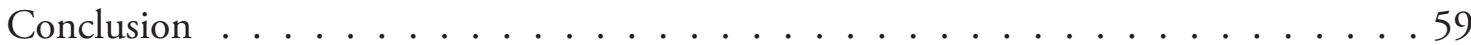

Supporting information . . . . . . . . . . . . . . . . . . 65

Chapter 4

Ant seed predation, pesticide applications and farmers' income from tropical $\begin{array}{ll}\text { multi-cropping gardens } & 68\end{array}$

Abstract . . . . . . . . . . . . . . . . . . . . . 69

Introduction . . . . . . . . . . . . . . . . . . . 70

Materials and methods . . . . . . . . . . . . . . . . 71

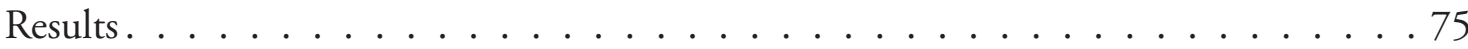


Discussion . . . . . . . . . . . . . . . . . . 78

Seed protection and management recommendations. . . . . . . . . . . . . . 82

Acknowledgements . . . . . . . . . . . . . . . . . 83

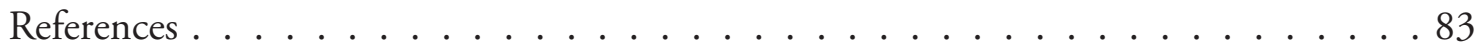

Supporting information . . . . . . . . . . . . . . . . . 90

\section{Chapter 5}

$\begin{array}{ll}\text { Services from plant-pollinator interactions in the Neotropics } & 103\end{array}$

Introduction . . . . . . . . . . . . . . . . . . . . . . 104

Determination of Crop Pollination Services . . . . . . . . . . . . . . 109

Management to Improve Pollination Services at the Landscape and Farm Scale . . . . 112

Socio-Economic Drivers Affecting Pollination Services . . . . . . . . . . . . 115

Conclusions . . . . . . . . . . . . . . . . . . . . . . 117

$\begin{array}{ll}\text { Acknowledgments } & 128\end{array}$

$\begin{array}{ll}\text { Curriculum Vitae } & 130\end{array}$

$\begin{array}{ll}\text { Publications } & 132\end{array}$ 


\section{SUMMARY}

Tropical countries contribute substantially to global agricultural production, but the majority of farmers are small-scale subsistence farmers. Their comparably low agricultural productivity is coupled with major yield gaps. Agricultural expansion and the intensive use of agro-chemicals are the major cause for the destruction of tropical habitats and biodiversity loss and pose a threat to ecosystem services. However, many tropical small-holder farmers rely on ecosystem services like insect pollination or natural pest control, which may play an indispensable role in closing yield gaps. In addition, losses from pollination deficits or pest pressure are usually mitigated by the use of managed pollinators or pesticides that in turn can be harmful to ecosystem services provided by wild insects.

We aim to shed light on the relative importance of pollination services, common management practices and their interaction. We evaluated the benefits from pollination services for cucumber (Cucumis sativus) production and how wild bees (the main cucumber pollinators in the region) are influenced by management on four different spatial scales. We furthermore assessed income loss due to dis-services from seed predating ants in order to suggest management measures that may reduce yield gaps. Our work comprises experimental field studies on small-scale vegetable production in homegardens in tropical central Sulawesi, Indonesia and a review on pollination services to highlight existing information and to close information gaps on pollinations services for crops.

In the first study (chapter 2) we tested how different management practices (insect pollination, weed control, fertilization and herbivore control) affect cucumber fruit set and yield and how these variables influence each other. We found that insect pollination, fertilization and weed control increased crop fruit set and yield in an additive way. However, fertilization and weed control alone could not compensate for pollination loss, which was the most important driver and accounted for $75 \%$ of the yield. We found an interaction between the weed control and pollination treatment in which weed control strongly influenced insect-pollinated plants but not wind and self-pollinated plants. This indicates that weed control contributes to closing yield gaps, but only in addition to insect pollination. In contrast, insecticides to control herbivores did not influence yield. We recommend shifting the focus from common management practices towards more sustainable management to enhance pollination services and stress the importance for policy driven regulations of reduced and better targeted pesticide application in tropical agroecosystems.

In the second study (chapter 3), we evaluated variables from three spatial scales to better 
understand bee communities indispensable for cucumber production. We further assessed if the response to these scale predictors depends on pollinator body size and sociality. Yield increased significantly with increasing number of flower-visiting bee individuals (mainly composed of wild solitary bees which translates into a net income decline of $47 \%$ if half of the bees would be lost. For optimized bee management, farmers need to consider four spatial scales. On the garden scale (1), the homegarden-wide percentage of flower cover predicted pollinator attraction best, if, on the adjacent-habitat scale (2), a higher percentage of homegardens (at least $20 \%$, best $50 \%$ in a $200 \mathrm{~m}$ radius) surrounded the study garden. In addition, the landscape scale (3), distance to the rainforest (up to $2.2 \mathrm{~km}$ ) had also a significant effect on total bee flower visitor. This effect was dominated by small bees which increased closer to the forest. We conclude that farmers need to adjust bee management accordingly to reduce major yield gaps. High percentages of crops and non-crop plants flowering inside the homegarden can attract pollinators from adjacent source habitats that are mainly homegardens as well.

In the third study (chapter 4), we aimed to assess the effect of seed predation by ants on sown seeds of four crop species (C. sativus, Daucus carota, Capsicum frutescens and Solanum melongena) and the resulting impact on the net income of small-scale farmers. Furthermore, we tested if ant seed predation differs with or without insecticide and herbicide applications. We found that ant seed predation was high for all crops $(42.0 \%, 49.4 \%, 48.0 \%$ and $50.6 \%$ for C. sativus, D. carota, C. frutescens and S. melongena, respectively), potentially reducing farmers' net income by half. Application of insecticides and herbicides did not influence ant seed predation or total ant abundance, but influenced ant species-specific abundances positively or negatively. Despite ant species-specific responses to insecticide and herbicide applications, we found consistently high seed predation rates across all gardens. We conclude that high seed predation is caused by high overall ant abundance mediated through functional redundancy of ant species. We recommend more environmentally friendly and sustainable practices such as overseeding or seedling production in nurseries to reduce chemical pest control.

In the fourth study (chapter 5), we reviewed pollination services and their importance to crops focusing on another understudied geographical region - the Neotropics - to get an overview of the main pollinator taxa and the dependence on pollination services of crops. In addition, we summarized pollination research methodologies and discuss pollination relevant farm and landscape management, as well as socio-economic drivers affecting pollination services. We have shown that pollination services by wild pollinators are important for crop production. However, knowledge gaps exist in terms of the quantity, quality and stability of crop production provided by 
animal pollinators. It is also critical to understand how multiple socioeconomic drivers influence the selection of particular management systems and, thus, the environmental services delivered.

In conclusion, pollination services are of major importance for closing yield gaps in tropical small-scale agriculture, such as homegardens. Although common management practices such as the use of agro-chemicals influence yield, they do not compensate yield gaps due to pollinator loss or ant seed predation. The enhancement of pollination services should be considered as well as the reduction of pesticide use in the majority of tropical agroecosystems. Farmers should adapt environmentally friendly and more sustainable practices adjusted to bee management considering four spatial scales to reduce major yield gaps. 


\section{Chapter I}

\section{General Introduction}




\section{TropicAl AGRICUlTURE, YIELD GAPS AND ECOSYSTEM SERVICES}

Tropical ecosystems are threatened by large-scale land-use change (Achard et al. 2002; Laurance 2007), especially by expansion of agriculture (Tilman et al. 2002; Gibbs et al. 2010; Dobrovolski et al. 2011), leading to deforestation, biodiversity decline and environmental pollution. Demand for agricultural products and, thus, expansion of agricultural land still increases due to a growing human population and an increase in living standards and consumption (Godfray et al. 2010). Tropical countries experience highest growth rates making these areas even more prone to environmental destruction (Kastner et al. 2012; United Nations 2013). At the same time tropical ecosystems contain more than half of the world's biodiversity hotspots (Myers 2003) and are crucial for global biodiversity and ecosystem services (Grimes et al. 1994). Ecosystem services provided to people comprise provisioning (such as food, crops, genetic resources, water), regulating (such as climate regulation, pest control, animal pollination), cultural (such as spiritual and recreational experiences), and supporting (such as nutrient cycling and seed dispersal) services. Many of these services are currently under threat, including services important for agriculture such as crop pollination (Assessment Millennium Ecosystem 2005). In large parts of the tropics agriculture is dominated by small-scale farmers lacking access to modern technologies (Masters et al. 2013; Sayer \& Cassman 2013), often producing inefficiently resulting in large gaps between actual and potential farm yields (Mueller et al. 2012; Carberry et al. 2013). These small-scale farms are most susceptible to environmental degradation as they rely most on functioning ecosystem services (Díaz et al. 2006). One solution to meet future demands for agricultural products would be to reduce yield gaps by increasing productivity (Bruinsma 2009). This can be achieved either by conventional intensification with known negative effects on the environment (Brittain \& Potts 2011; Tscharntke et al. 2012) or, alternatively, by environmentally friendly management relying more on ecosystem services, such as natural pest control or pollination (Fig. 1, Foley et al. 2011; Bommarco, Kleijn $\&$ Potts 2012). Past studies have shown that it is possible to achieve high yields without losing biodiversity or ecosystem services (Perfecto et al. 2007; Perfecto \& Vandermeer 2010; Clough et al. 2011), but this needs effective planning and regulation of agriculture. Farm management practices and ecosystem services can limit crop production and, thus, factors contributing to yield gaps need to be identified. Management practices as well as ecosystem services and dis-services need to be evaluated starting from the seed to farmers net income. 


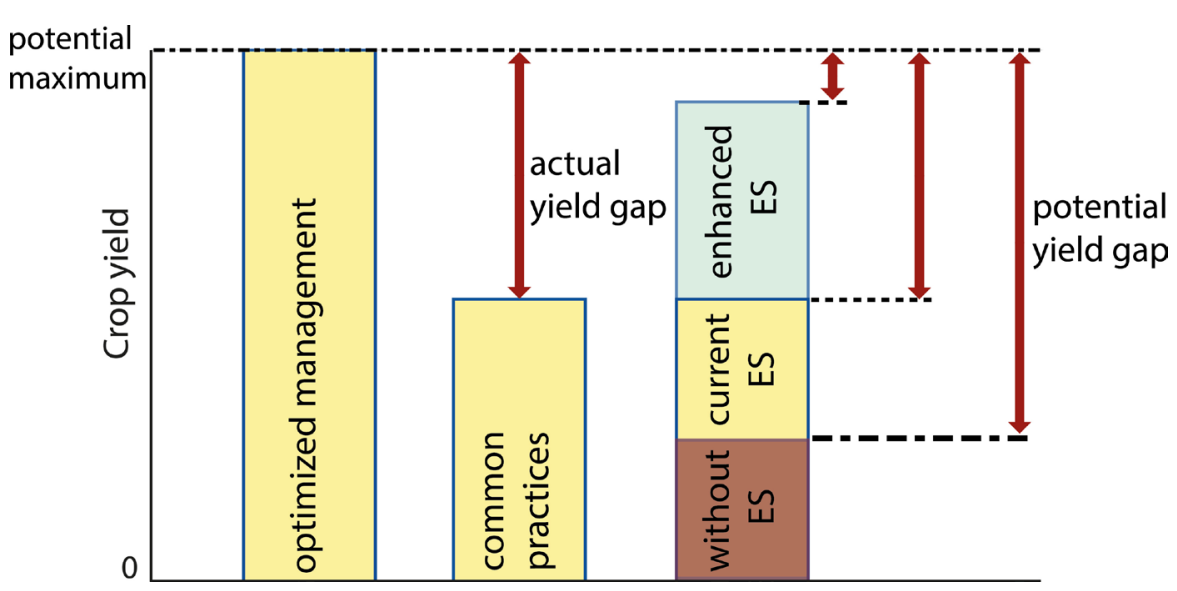

Fig. 1: Theoretical concept of yield gaps. Maximum potential represent the yields that potentially can be achieved by farmers within the given climatic and geographic conditions. Common management practices in the tropics lead to lower yield than potentially achievable and, thus, high yield gaps. These practices represent yields at the current state of ecosystem services (ES). By losing ES, famers risk even higher yield gaps. By promoting ES such as animal pollination farmers may reduce these gaps. To achieve maximum yields, farmers may have to combine several management practices including ecosystem services and conventional methods, but this needs adjusted research.

\section{ECOSYSTEM SERVICES AND DIS-SERVICES BY INSECTS IN TROPICAL AGRO-ECOSYSTEMS}

One ecosystem service of high commercial and social importance for agriculture is pollination by animals (Klein et al. 2007; Gallai et al. 2009; Winfree, Gross \& Kremen 2011). About 75 $\%$ of the world's leading food crops depend on animal pollination, with bees being the main pollinators (Klein et al. 2007). The value to global food crop production by animal pollination has been estimated to be $€ 153$ billion. This corresponds to $9.5 \%$ of the total agricultural production (Gallai et al. 2009). Crop yield and quality are positively related and more stable with higher pollinator visitation rate and diversity (Hoehn et al. 2008; e.g., Garibaldi et al. 2011). However, pollinators are declining worldwide (Potts et al. 2010; Bommarco, Kleijn \& Potts 2012), mainly due to habitat loss and fragmentation, pesticides, and diseases (Potts et al. 2010; Schweiger et al. 2010). This may endanger the services pollinators provide (Aizen \& Harder 2009). Despite research increasingly focuses on pollination services, knowledge gaps still exist (summarized in Mayer et al. 2011). For example, information on the importance of pollination services in relation to common management practices, as well as how pollinator communities in turn are affected by landscape and farm management is scarce at various scales (Ghazoul 2007; Potts et al. 2010). In addition, even less attention has been paid to the pollination of tropical crops (Roubik 1995). However, as the tropics are most prone to environmental destruction - information on pollination services in the tropics 
can be of great impact for effective conservation strategies to ensure that yield gaps are minimized.

Not only the decline of ecosystem services such as crop pollination, but also the emergence of dis-services like pest pressure contribute to yield gaps. Pest pressure in tropics can be high often leading to intensive use of agrochemicals (Wanger, Rauf \& Schwarze 2010). Especially in the tropics, ants are important for ecosystem services in agricultural landscapes (Eubanks 2001; Perfecto et al. 2007) as on the one hand they provide pest control (Armbrecht \& Gallego 2007; Philpott, Perfecto \& Vandermeer 2008). On the other hand they exert dis-services since they can transmit diseases (Wielgoss et al. 2014), protecting aphid pest from predators (Davidson et al. 2003), or consume crop seeds (Litsinger 2009). In the tropics, ants are among the most important seed predators (Albert, Escudero \& Iriondo 2005; Hulme \& Kollmann 2005; Vander Wall 2005), which can have substantial impact on farmer's income. Farmers often counteract predation of newly sown seeds with insecticides such as imidacloprid (a neonicotinoid) and carbofuran (a carbamate) (Munkvold 2009; Almeida 2010), risking the pollution of the environment and the poisoning of non-target species. However, sown-seed predation by ants has rarely been studied, especially in tropical countries.
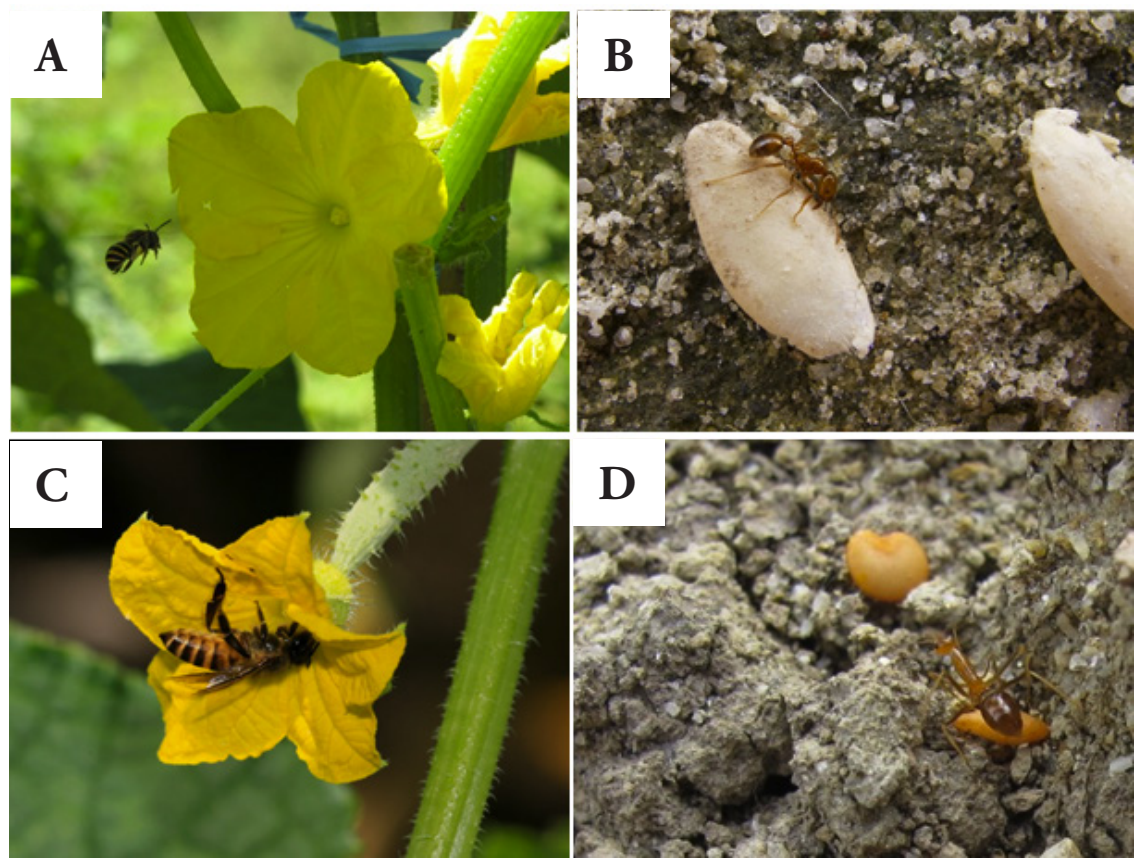

Bees visiting cucumber flowers (A: Nomia sp.; C: Apis sp. (CFlorian Lauer) and ants approaching crop seeds (B: Solenopsis geminata; D: Anoplolepis gracilipes). 


\section{STUDY REGION AND EXPERIMENTAL DESIGN}

\section{STUDY REGION}

The main experiment was conducted in homegardens in the Napu valley (Lore Utara) in Central Sulawesi, Indonesia (Fig. 2). The valley consists of a mosaic of natural forest and small-scale agriculture bordering the Lore Lindu National Park. Most inhabitants are farmers of paddy rice, cacao and vegetables (Van Rheenen et al. 2004). The climate is mild and rather constant throughout the year (annual temperature of $24.0 \pm 0.16^{\circ} \mathrm{C}($ mean $\pm S D)$ and monthly rainfall of $143.7 \pm 22.7 \mathrm{~mm}$ (mean \pm SD), $1100-1200 \mathrm{~m}$ a.s.l), providing optimal conditions for vegetable production yearround. Vegetable production is increasing to cover the demand of local markets in the neighboring cities (Weber et al. 2007).

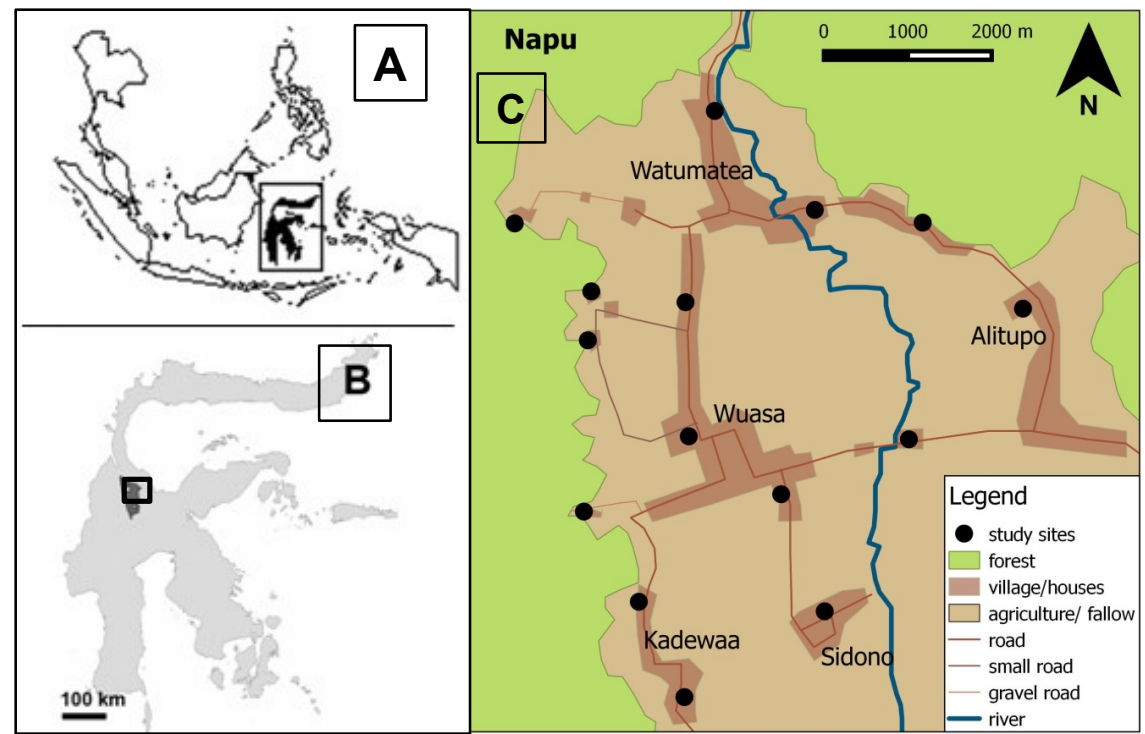

Fig. 2: Map of the study area. A: Indonesia with the island of Sulawesi; B: Sulawesi with the study area located in Central Suawesi; C Map of the northern part of the Napu Vally with the study gardens and villages.

In the Napu valley, most households have traditional gardens next to their houses. Tropical homegardens have a long history (Soemarwoto \& Conway 1992; Kumar \& Nair 2004), and are generally complex, species-rich agroforestry systems with multi-layered vegetation structures harboring a large diversity of both cultivated and wild plant species as well as providing refuge for animals (e.g., Michon \& Mary 1994; Albuquerque, Andrade \& Caballero 2005; Kehlenbeck 2007; Mohri et al. 2013). They can be considered as a model for a sustainable agricultural system, in which they play an important role for subsistence production, but are also of economic importance, and fulfill cultural and social functions (Kumar \& Nair 2004; Kehlenbeck, Arifin \& Maass 2007; 
Mohri et al. 2013). Homegardens in the study area are highly diverse agroforestry systems with mostly multi-layered vegetation structures ranging from open ground to grasses, shrubs and trees (Kehlenbeck 2007). However, herbicides and insecticides are already used, but mostly by migrant farmers (Kehlenbeck 2007). Information about persistence of pollinator populations in homegarden-dominated landscapes large enough to sustain crop yield is scarce (Webb \& Kabir 2009; Mohri et al. 2013).
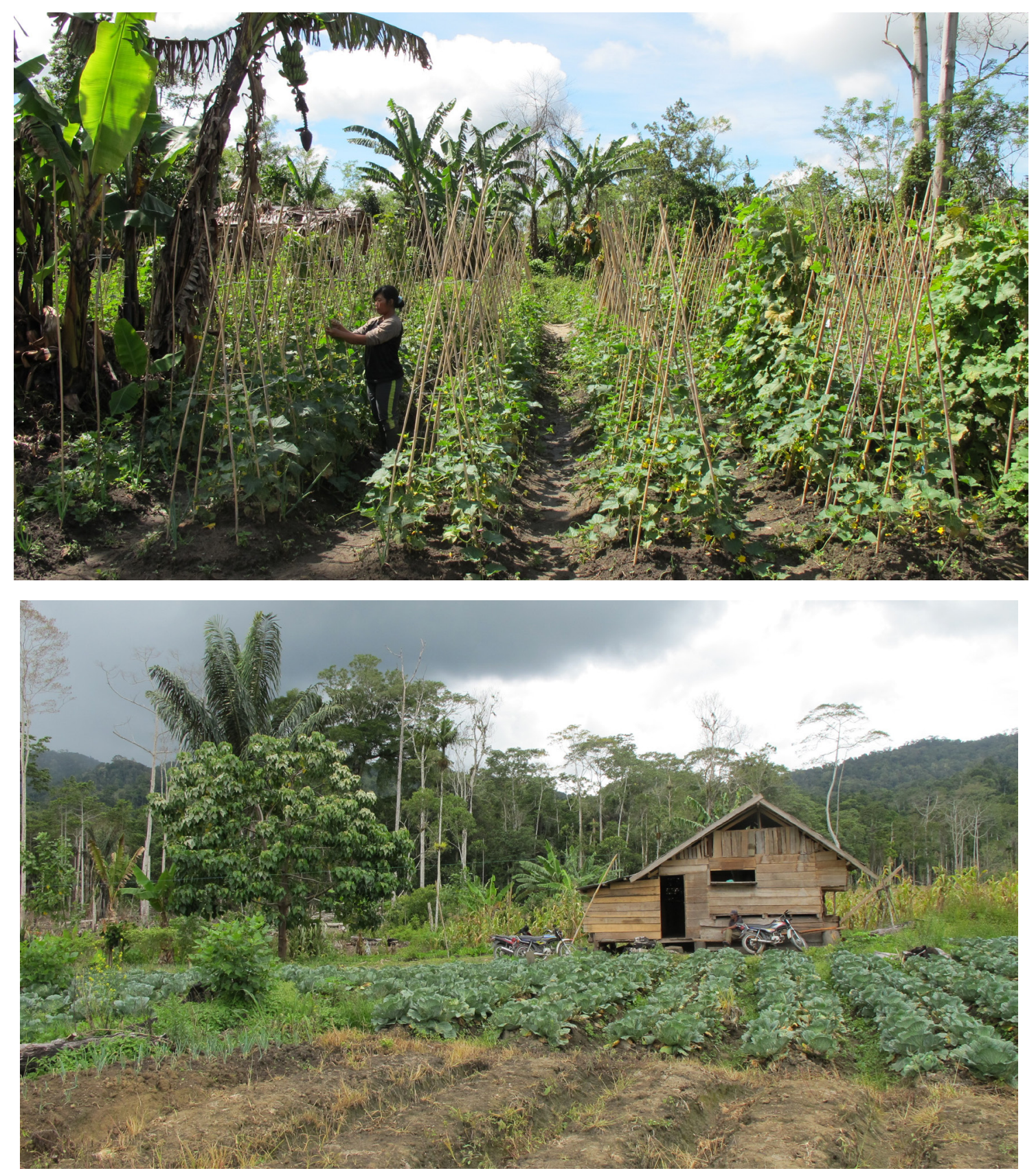

A: a homegarden near the forest edge, B: a small-scale cucumber garden. 


\section{DESIGN OF THE MAIN EXPERIMENT}

For the first three studies we established an experiment in a full-factorial split plot design (Fig. 3) within homegardens that differed in distance to the rainforest $(0-2500 \mathrm{~m})$. We selected 15 homegardens (only 13 were used for the first two studies) were we chose an area of $300 \mathrm{~m}^{2}$ which was divided into eight subplots of $3 \times 6 \mathrm{~m}$ in which we planted our study crops. We applied the following treatments to determine the individual and combined effects of different management variables (treatments) on crop yield in an experimental split plot design: (1) weed control (weekly herbicide application and manual weeding) versus no weed control, (2) fertilization (weekly fertilizer application) versus no fertilization, (3) and herbivore control (weekly insecticide application) versus no herbivore control. This resulted in eight subplots each treated with a different treatment combination. Each of these treatments was further subdivided into (4) self- and wind pollination (with exclusion cages) versus supplementary (open) insect pollination.
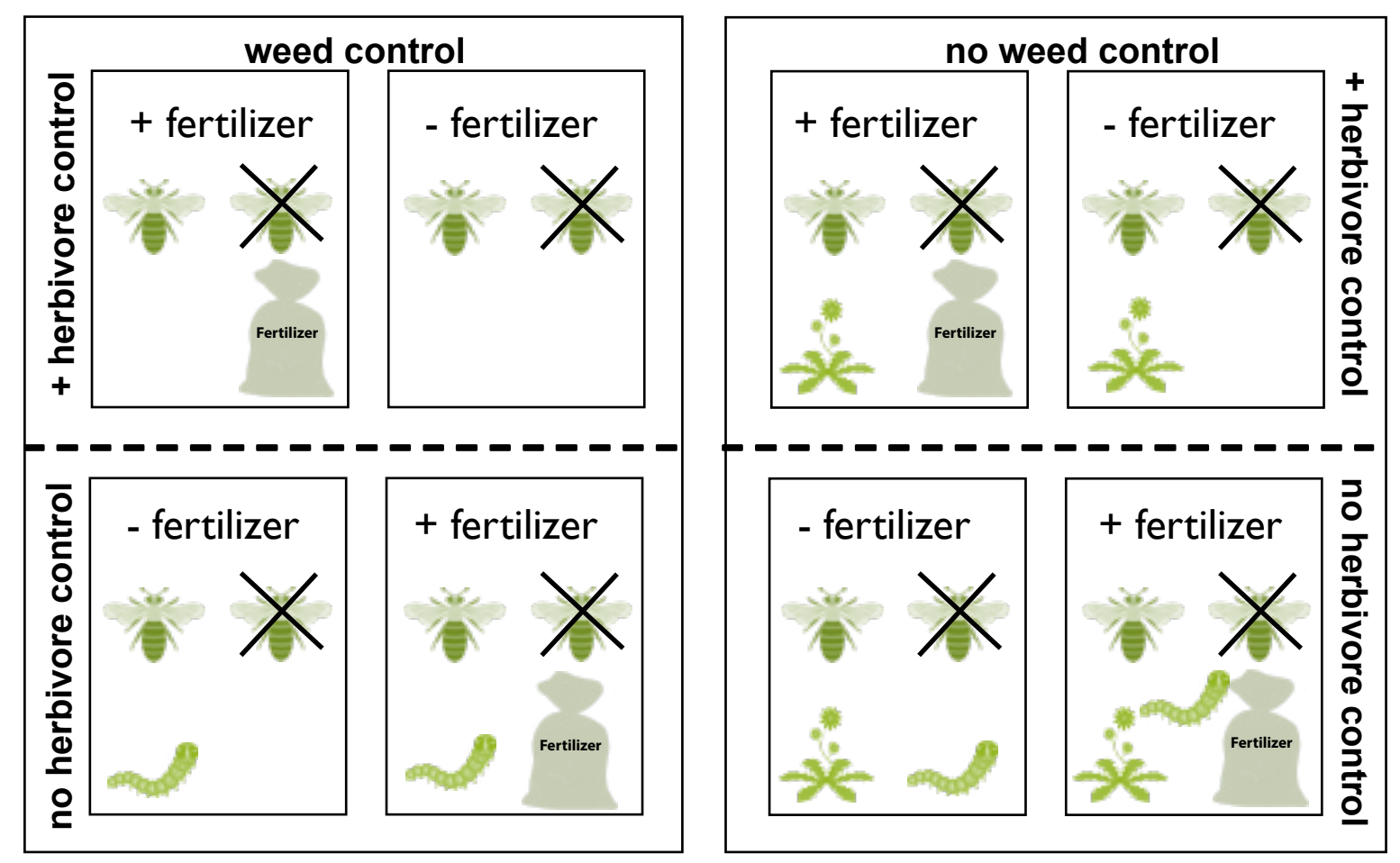

Fig. 3: Experimental split plot design of treatment applications. The area of $300 \mathrm{~m}^{2}$ in each garden was split three times into half with first weed and no weed control, then herbivore and no herbivore control, and with fertilization or without fertilization on each half resulting in eight subplots. One half of the cucumber plants was left for insect pollination and the other half was caged to exclude insects during flowering. 


\section{RESEARCH AIMS}

In this thesis we give a broad perspective of bee pollination services and dis-services by ants in relation to common management practices of small-scale vegetable production and determine the drivers of yield gaps to provide adequate management recommendations. This thesis comprises three experimental studies on pollination services (chapter $2+3$ ) and ant- seed predation (chapter 4 ) in Central Sulawesi, Indonesia. The last chapter is a literature review on crop pollination services in another tropical region - the Neotropics.

In chapter 2 our aim was to study the relative importance of pollination services compared and in interaction with other common management practices and how direct and interactions effects contributes to closing yield gaps. We experimentally tested how pollination (insect versus wind and self- pollination) interacts with weed control, fertilization as well as herbivore control and how this influences fruit set and yield of cucumber (Cucumis sativus) and net revenues of local smallholder farmers.

In chapter 3 we studied the overall benefits of crop pollination by bees for small-scale cucumber production in homegardens. We further assessed how bees (total bee abundances, bee sociality and body size) in turn are influenced by management practices on three different spatial scales: garden (homegarden-wide percentage of flower cover), adjacent-habitat (percentage of adjacent homegarden) and landscape scale (forest distance).

In chapter 4 we aimed to assess the relevance of ants in the predation of newly sown seeds of four crop species: cucumber, carrot (Daucus carota), chili (Capsicum frutescens), and eggplant (Solanum melongena) and the resulting impact on the net income of Indonesian farmers. Furthermore, we were interested in how seed predation and ant communities are influenced by common management practices such as herbicides and insecticide application also along a forest distance gradient.

In chapter 5 I contributed to a review on pollination services for crops. We aimed to summarize pollination services for another tropical hotspot area - the Neotropics. For this we reviewed literature on pollinator groups and on crops depending on pollination. We further summarized the main methods to evaluate pollination services and discuss management options for enhanced pollination services. 


\section{GENERAL CONCLUSION}

In our studies we focused on traditional tropical homegardens which are important not only for food production of small-scale farmers, but also for wildlife, offering refuge habitat to many species. In many tropical countries like in Indonesia, demand for food production, and especially vegetables, is rising and farmers aim to increase production. However, they often lack knowledge about how to manage their farming system sustainably. Recently, traditional management is more and more replaced by an increasing use of external resources such as pesticides and fertilizers. These now common management practices are often not well adapted and may lead to negative impacts on the environment. Farmers are not aware of the benefits or necessity of including ecosystem services into their management practices. Overall ecosystem services and dis-services influence plant production, and common management can be improved to close yield gaps. In our studies we could show that pollination services by animal pollinators are important for crop production in the Neotropics in general and with a regional focus for cucumber production in Indonesian homegardens. Solving the challenge of closing yield gaps and environmental protection through the conservation of pollinators is one of the key challenges for smallholder farmers in the tropics, since most of their crops need efficient pollination. The common management of fertilization and weed control was also important for production, but only in addition to insect pollination. The often applied herbivore control through insecticides had no effect on fruit set or yield and was inefficient and little targeted. Farmers can mitigate crop yield losses in homegardens related to pollination deficits by adapted bee management on multiple spatial scales. In addition, common management practices could also not affect ant seed predation, which had the high rate of $50 \%$ of the seeds of all crops. In conclusion, more holistic approaches integrating interactions among different management practices and spatial scales that are tailored to the regional context are needed to mitigate crop yield gaps and to sustain a viable future of agriculture. It is important to consider a broader perspective on sustainable management to improve or even start with conservation strategies that maintain ecosystem services, especially pollination services, for the future. 


\section{REFERENCES}

Achard, F., Eva, H.D., Stibig, H.-J., Mayaux, P., Gallego, J., Richards, T. \& Malingreau, J.-P. (2002) Determination of deforestation rates of the world's humid tropical forests. Science, 297, 999-1002.

Aizen, M.A. \& Harder, L.D. (2009) The global stock of domesticated honey bees is growing slower than agricultural demand for pollination. Current Biology, 19, 915-918.

Albert, M.J., Escudero, A. \& Iriondo, J.M. (2005) Assessing ant seed predation in threatened plants: a case study. Acta Oecologica-International Journal of Ecology, 28, 213-220.

Albuquerque, U.d., Andrade, L. \& Caballero, J. (2005) Structure and floristics of homegardens in Northeastern Brazil. Journal of arid environments, 62, 491-506.

Almeida, A. (2010) Are camouflaged seeds less attacked by wild birds? Scientia agricola, 67, 170.

Armbrecht, I. \& Gallego, M.C. (2007) Testing ant predation on the coffee berry borer in shaded and sun coffee plantations in Colombia. Entomologia experimentalis et applicata, 124, 261267.

Assessment Millennium Ecosystem (2005) Ecosystems and human well-being. Island Press Washington, DC.

Bommarco, R., Kleijn, D. \& Potts, S.G. (2012) Ecological intensification: harnessing ecosystem services for food security. Trends in ecology \& evolution.

Brittain, C. \& Potts, S.G. (2011) The potential impacts of insecticides on the life-history traits of bees and the consequences for pollination. Basic and Applied Ecology, 12, 321-331.

Bruinsma, J. (2009) The resource outlook to 2050. expert meeting on "How to Feed the World in 2050.

Carberry, P.S., Liang, W.-l., Twomlow, S., Holzworth, D.P., Dimes, J.P., McClelland, T., Huth, N.I., Chen, F., Hochman, Z. \& Keating, B.A. (2013) Scope for improved eco-efficiency varies among diverse cropping systems. Proceedings of the National Academy of Sciences, $110,8381-8386$

Clough, Y., Barkmann, J., Juhrbandt, J., Kessler, M., Wanger, T.C., Anshary, A., Buchori, D., Cicuzza, D., Darras, K. \& Putra, D.D. (2011) Combining high biodiversity with high yields in tropical agroforests. Proceedings of the National Academy of Sciences, 108, 83118316.

Díaz, S., Fargione, J., Chapin III, F.S. \& Tilman, D. (2006) Biodiversity loss threatens human wellbeing. PLoS Biology, 4, e277. 
Dobrovolski, R., Diniz-Filho, J.A.F., Loyola, R.D. \& Júnior, P.D.M. (2011) Agricultural expansion and the fate of global conservation priorities. Biodiversity and Conservation, 20, 24452459.

Eubanks, M.D. (2001) Estimates of the direct and indirect effects of red imported fire ants on biological control in field crops. Biological Control, 21, 35-43.

Foley, J.A., Ramankutty, N., Brauman, K.A., Cassidy, E.S., Gerber, J.S., Johnston, M., Mueller, N.D., O’Connell, C., Ray, D.K. \& West, P.C. (2011) Solutions for a cultivated planet. Nature, 478, 337-342.

Gallai, N., Salles, J.-M., Settele, J. \& Vaissière, B.E. (2009) Economic valuation of the vulnerability of world agriculture confronted with pollinator decline. Ecological economics, 68, 810-821.

Garibaldi, L.A., Steffan-Dewenter, I., Kremen, C., Morales, J.M., Bommarco, R., Cunningham, S.A., Carvalheiro, L.G., Chacoff, N.P., Dudenhoeffer, J.H. \& Greenleaf, S.S. (2011) Stability of pollination services decreases with isolation from natural areas despite honey bee visits. Ecology letters, 14, 1062-1072.

Ghazoul, J. (2007) Challenges to the uptake of the ecosystem service rationale for conservation. Conservation Biology, 21, 1651-1652.

Gibbs, H., Ruesch, A., Achard, F., Clayton, M., Holmgren, P., Ramankutty, N. \& Foley, J. (2010) Tropical forests were the primary sources of new agricultural land in the 1980s and 1990s. Proceedings of the National Academy of Sciences, 107, 16732-16737.

Godfray, H.C.J., Beddington, J.R., Crute, I.R., Haddad, L., Lawrence, D., Muir, J.F., Pretty, J., Robinson, S., Thomas, S.M. \& Toulmin, C. (2010) Food security: the challenge of feeding 9 billion people. Science, 327, 812-818.

Grimes, A., Loomis, S., Jahnige, P., Burnham, M., Onthank, K., Alarcón, R., Cuenca, W.P., Martínez, C.C., Neill, D. \& Balick, M. (1994) Valuing the rain forest: the economic value of nontimber forest products in Ecuador. Ambio, 405-410.

Hoehn, P., Tscharntke, T., Tylianakis, J.M. \& Steffan-Dewenter, I. (2008) Functional group diversity of bee pollinators increases crop yield. Proceedings of the Royal Society B: Biological Sciences, 275, 2283-2291.

Hulme, P.E. \& Kollmann, J. (2005) Seed predator guilds, spatial variation in post-dispersal seed predation and potential effects on plant demography: a temperate perspective. Seed fate: predation and secondary dispersal (Forget PM, Lambert JE, Hulme PE, Vander Wall SB, eds). Wallingford: CAB International, 9-30.

Kastner, T., Rivas, M.J.I., Koch, W. \& Nonhebel, S. (2012) Global changes in diets and the 
consequences for land requirements for food. Proceedings of the National Academy of Sciences, 109, 6868-6872.

Kehlenbeck, K. (2007) Rural homegardens in Central Sulawesi, Indonesia: an example for a sustainable agro-ecosystem. Doctoral Disseration. Faculty of Agriculture. UniverSity of Gottingen, Germany.[On-line] http://webdoc. sub. gwdg. de/diss/2007/kehlenbeck/ kehlenbeck. pdf.

Kehlenbeck, K., Arifin, H.S. \& Maass, B.L. (2007) Plant diversity in homegardens in a socioeconomic and agro-ecological context. Stability of Tropical Rainforest Margins, pp. 295317. Springer.

Klein, A.M., Vaissiere, B.E., Cane, J.H., Steffan-Dewenter, I., Cunningham, S.A., Kremen, C. \& Tscharntke, T. (2007) Importance of pollinators in changing landscapes for world crops. Proceedings of the Royal Society B: Biological Sciences, 274, 303-313.

Kumar, B.M. \& Nair, P.R. (2004) The enigma of tropical homegardens. Agroforestry Systems, 61, $135-152$

Laurance, W.F. (2007) Forest destruction in tropical Asia. Current Science (00113891), 93.

Litsinger, J.A. (2009) Comparison of insect pest complexes in different Philippine dryland rice environments: population densities, yield loss, and management. International journal of pest management, 55, 129 .

Masters, W.A., Djurfeldt, A.A., De Haan, C., Hazell, P., Jayne, T., Jirström, M. \& Reardon, T. (2013) Urbanization and farm size in Asia and Africa: Implications for food security and agricultural research. Global Food Security, 2, 156-165.

Mayer, C., Adler, L., Armbruster, S., Dafni, A., Eardley, C., Huang, S., Kevan, P., Ollerton, J., Packer, L. \& Ssymank, A. (2011) Pollination ecology in the 21st century: key questions for future research. Journal of Pollination Ecology, 3, 8-23.

Michon, G. \& Mary, F. (1994) Conversion of traditional village gardens and new economic strategies of rural households in the area of Bogor, Indonesia. Agroforestry Systems, 25, 31-58.

Mohri, H., Lahoti, S., Saito, O., Mahalingam, A., Gunatilleke, N., Hoang, V.T., Hitinayake, G., Takeuchi, K. \& Herath, S. (2013) Assessment of ecosystem services in homegarden systems in Indonesia, Sri Lanka, and Vietnam. Ecosystem Services, 5, 124-136.

Mueller, N.D., Gerber, J.S., Johnston, M., Ray, D.K., Ramankutty, N. \& Foley, J.A. (2012) Closing yield gaps through nutrient and water management. Nature, 490, 254-257.

Munkvold, G.P. (2009) Seed pathology progress in academia and industry. Annual review of phytopathology, 47, 285. 
Myers, N. (2003) Biodiversity hotspots revisited. Bioscience, 53, 916-917.

Perfecto, I., Armbrecht, I., Philpott, S.M., Soto-Pinto, L. \& Dietsch, T.V. (2007) Shaded coffee and the stability of rainforest margins in northern Latin America. Stability of Tropical Rainforest Margins, pp. 225-261. Springer.

Perfecto, I. \& Vandermeer, J. (2010) The agroecological matrix as alternative to the land-sparing/ agriculture intensification model. Proceedings of the National Academy of Sciences, 107, 5786-5791.

Philpott, S., Perfecto, I. \& Vandermeer, J. (2008) Effects of predatory ants on lower trophic levels across a gradient of coffee management complexity. Journal of animal ecology, 77, 505-511.

Potts, S.G., Biesmeijer, J.C., Kremen, C., Neumann, P., Schweiger, O. \& Kunin, W.E. (2010) Global pollinator declines: trends, impacts and drivers. Trends in ecology \& evolution, 25, $345-353$.

Roubik, D.W. (1995) Pollination of cultivated plants in the tropics. Food \& Agriculture Org.

Sayer, J. \& Cassman, K.G. (2013) Agricultural innovation to protect the environment. Proceedings of the National Academy of Sciences, 110, 8345-8348.

Schweiger, O., Biesmeijer, J.C., Bommarco, R., Hickler, T., Hulme, P.E., Klotz, S., Kühn, I., Moora, M., Nielsen, A. \& Ohlemüller, R. (2010) Multiple stressors on biotic interactions: how climate change and alien species interact to affect pollination. Biological Reviews, 85, 777-795.

Soemarwoto, O. \& Conway, G. (1992) The javanese homegarden. Journal for Farming Systems Research-Extension, 2, 95-118.

Tilman, D., Cassman, K.G., Matson, P.A., Naylor, R. \& Polasky, S. (2002) Agricultural sustainability and intensive production practices. Nature, 418, 671-677.

Tscharntke, T., Clough, Y., Wanger, T.C., Jackson, L., Motzke, I., Perfecto, I., Vandermeer, J. \& Whitbread, A. (2012) Global food security, biodiversity conservation and the future of agricultural intensification. Biological Conservation, 151, 53-59.

United Nations (2013) World Population Prospects: The 2012 Revision. (ed. U.N.P.D. (2013)).

Van Rheenen, T., Elbel, C., Schwarze, S., Nuryartono, N., Zeller, M. \& Sanim, B. (2004)

Encroachments on Primary Forests: Are They Really Driven by Despair? Land Use, Nature Conservation and the Stability of Rainforest Margins in Southeast Asia (eds G. Gerold, M. Fremerey \& E. Guhardja), pp. 199-213. Springer Berlin Heidelberg.

Vander Wall, S.B. (2005) Seed removal, seed predation, and secondary dispersal. Ecology, 86, 801. Wanger, T.C., Rauf, A. \& Schwarze, S. (2010) Pesticides and tropical biodiversity. Frontiers in 
Ecology and the Environment, 8, 178-179.

Webb, E.L. \& Kabir, M.E. (2009) Home gardening for tropical biodiversity conservation. Conservation Biology, 23, 1641-1644.

Weber, R., Faust, H., Schippers, B., Mamar, S., Sutarto, E. \& Kreisel, W. (2007) Migration and ethnicity as cultural impact factors on land use change in the rainforest margins of Central Sulawesi, Indonesia. Stability of Tropical Rainforest Margins, pp. 415-434. Springer.

Wielgoss, A., Tscharntke, T., Rumede, A., Fiala, B., Seidel, H., Shahabuddin, S. \& Clough, Y. (2014) Interaction complexity matters: disentangling services and disservices of ant communities driving yield in tropical agroecosystems. Proceedings of the Royal Society B: Biological Sciences, 281, 20132144.

Winfree, R., Gross, B.J. \& Kremen, C. (2011) Valuing pollination services to agriculture. Ecological economics, 71, 80-88. 


\section{Chapter 2}

\section{Pollination Mitigates CUCUMber YIELD GAPS MORE THAN PESTICIDE AND FERTILIZER USE IN TROPICAL SMALLHOLDER GARDENS}

Authors: Iris Motzke, Teja Tscharntke, Thomas C. Wanger, AleXandra-Maria Klein 


\begin{abstract}
1. Pollination can be an essential but often neglected ecosystem service to mitigate crop yield gaps. Pollination services are usually studied in isolation, and their relative role and possible interactions with other factors, such as major management practices, is little understood.

2. We tested how pollination (insect vs. wind- and self-pollination) interacts with weed control, fertilization and insect herbivore control and how these factors as well as flower-visiting bees influence fruit set and yield of cucumber Cucumis sativus L. in 13 traditional Indonesian home gardens.

3. Although insect pollination, fertilization and weed control additively increased crop yield, fertilization and weed control alone could not compensate for pollination loss. Pollination individually accounted for $75 \%$ of the yield and was, hence, the most important driver of yield. In contrast, herbivore control through insecticides at commonly applied levels did not increase yield.

4. Yield strongly increased with higher number of flower-visiting bee individuals, while the number of bee individuals in turn was not influenced by weed control, fertilization or herbivore control, but increased with higher number of cucumber flowers.

5. Synthesis and applications. Although multiple management practices influence yield, they cannot compensate yield gaps from pollinator loss in cucumber smallholder production in Indonesia. Our results also show that the widespread use of insecticides without considering the impacts on pest reduction is uneconomical. Here, reducing insecticides caused no income loss and, at the same time, reduces potential risks to important pollinators, which needs to be acknowledged by policy-driven regulations for pesticide application in tropical agroecosystems. Our results stress the importance of enhancing bee populations to facilitate pollination services. Bee management practices, such as sustaining additional food resources for pollinators, need to be established.
\end{abstract}

Keywords: herbivore control, home garden, Indonesia, nutrients, pollination services, weed control, wild bees 


\section{INTRODUCTION}

Animal pollination can increase fruit and seed production in $75 \%$ of the major crops produced globally (Klein et al. 2007). Pollination services from both honeybees and wild pollinators are declining in some countries mainly through habitat destruction, diseases and the use of pesticides (Potts et al. 2010; Gonzalez-Varo et al. 2013; Vanbergen \& Initiative 2013). In particular, the importance of wild pollinators for crop pollination (Garibaldi et al. 2013) coupled with ongoing destruction of habitats for these pollinators (Bommarco et al. 2010) raises concern about how food security is affected (Tscharntke et al. 2012). In developing countries, the gap between actual farm yields and potential yields is often high and agricultural productivity low (De Vries, Rabbinge \& Groot 1997; Tilman et al. 2002; Mueller et al. 2012). In Indonesia, increasing human population growth and a shift towards more vegetable consumption has led to a rapidly growing demand for fresh vegetables (Kuswardhani, Soni \& Shivakoti 2013), but production levels are low (Natawidjaja et al. 2007). To reduce yield gaps, Indonesian small-scale farmers often use pesticides excessively due to limited legal regulations (e.g. Wanger, Rauf \& Schwarze 2010), which is likely to affect the availability of pollination services (e.g. Gill, Ramos-Rodriguez \& Raine 2012; Henry et al. 2012; Whitehorn et al. 2012). Pollination and common management practices such as fertilization, and controlling for weeds or herbivory, can positively or negatively contribute to yield gaps (Fig. S1, Supporting information, Bommarco, Kleijn \& Potts 2013). Pollination services, however, do not act in isolation, but might be influenced by these management practices (Bos et al. 2007; Andersson, Rundl€of \& Smith 2012). While the individual effects of these practices are well studied (e.g. Oerke 2006; Wissuwa, Mazzola \& Picard 2009), their combined effects (i.e. compensatory, competitive, synergistically or additively) on crop yield are largely unknown. Agricultural intensification building on high chemical inputs involves high potential risk due to pollinator reduction. The importance of pollination for crop production necessitates farmers choose environmentally friendly intensification of their agricultural systems (Bommarco, Kleijn \& Potts 2013). However, recommendations aimed exclusively at pollinator enhancement are unrealistic because other management practices such as weed and herbivore control are also relevant (e.g. Bos et al. 2007). In this context, the relative importance and interaction of pollination services and other management practices are particularly important to identify strategies reducing existing yield gaps and facilitating environmentally friendly management (Bommarco, Kleijn \& Potts 2013).

Here, we experimentally tested how interactions between pollination and other management 
variables such as fertilization, weed and herbivore control influences yield of cucumber and net revenues of local smallholder farmers.

\section{Methods}

\section{STUdY AREA AND CROP SPECIES}

The study was conducted in the northern end of the valley of Lore Utara (Napu), Central Sulawesi, Indonesia at the border of the Lore Lindu National Park. The mild tropical climate [annual temperature of $240 \pm 016{ }^{\circ} \mathrm{C}($ mean $\pm S D)$ and monthly rainfall of $1437 \pm 227 \mathrm{~mm}$ (mean $\left.\pm \mathrm{SD}\right)$ ] results from an elevation of 1100-1200 m a.s.l. and provides optimal growing conditions for vegetables like cucumber. The study area is embedded in paddy rice fields and cacao and smallscale vegetable plantations (Van Rheenen et al. 2004). Vegetable production became increasingly attractive with an increasing human population in the study area (Weber $e t$ al. 2007) and a general shift towards vegetable consumption from an increase in living standards (Natawidjaja et al. 2007). Home gardens in our study area are highly diverse (size ranges from 240 to $2400 \mathrm{~m}^{2}$ ) and are used for subsistence and cash income (Kehlenbeck \& Maass 2006). Cucumber Cucumis sativus L. is a self-compatible monoecious annual herb, depending on pollination by insects for up to $90 \%$ (McGregor 1976). Cucumbers are planted in small plantations or home gardens for subsidence and income to supply the markets in neighbouring cities. In Indonesia, cucumbers are amongst the top-10 vegetable commodities of the country and, hence, of significant economic importance (Natawidjaja et al. 2007).

\section{SELECTION OF GARDENS AND EXPERIMENTAL DESIGN}

We selected 13 home gardens as study sites with a respective minimum and maximum distance of 500-4000 m. In each home garden, we chose an area of $300 \mathrm{~m}^{2}$ and divided it into eight plots of $3 \times 6 \mathrm{~m}$. Before the experiment, weeds were removed manually and bed rows of $40 \mathrm{~cm}$ height, 1 $\mathrm{m}$ width and $10 \mathrm{~m}$ length were prepared. Prior to planting, we standardized soil conditions among the plots: $10 \mathrm{~L}$ of soil for each plant individual of each garden was removed, mixed with the soil from the other gardens and returned to provide similar soil conditions across the treatments and gardens for promoting similar seedling growth. Cucumber seeds (hybrid 'Natanz') were obtained from a local market. In each plot, we sowed 14 plant individuals in July 2010 by placing the seeds in the prepared mixed soil on the bed rows at distances of $50 \mathrm{~cm}$ between the plants. We fertilized ['ZA'; ingredients: ammonium (21\%), sulphate (24\%)] and treated all seedlings with an insecticide 
('Pounce 20EC;' ingredient: Permethrin $2004 \mathrm{~g} \mathrm{~L}^{-1}$ ), and then weeded all sites in the beginning of the study to provide equal conditions for the survival of seedlings. We also supported cucumber vines with reed sticks and pruned them to one single central stem and two side stems.

We applied the following treatments to determine the individual and combined effects of different management variables (treatments) on crop yield in an experimental split-plot design: (i) weed control vs. no weed control, (ii) fertilization vs. no fertilization, (iii) herbivore control vs. no herbivore control. Each of these treatments were further combined with (iv) wind- and selfpollination vs. (open) insect pollination.

For all these treatments, we defined a priori the expected outcome of the treatment, which was positively (i.e. insect pollination, weed control, fertilization and herbivore control) or negatively (i.e. wind- and self-pollination only, no weed control, no fertilization and no herbivore control). Each of the 13 sites (blocks) was halved with each half treated by one treatment combination, starting with the weed treatment; followed by the herbivory treatment; and fertilization treatment (plots) (Fig. S2, Supporting information). This resulted in eight plots per site each treated with a different treatment combination. In each plot, pollinators had free access to seven plants (subplot) and were excluded from seven other plants by caging the whole plants during the $2-3$ week flowering period with plastic mesh (mesh size: $1 \mathrm{x} 1 \mathrm{~mm}$ ). However, due to strong and continuous rainfall during our experiments only three to seven plants per treatment combination (subplot) survived. Cages were controlled every second day for pollinators and plants with defect cages (pollinators inside) excluded from the analysis. By contrasting, the open vs. the caged flowers, we assessed the contribution of insect pollination to fruit production. We applied a herbicide ('Noxon'; ingredient; paraquat-dichlorid $297 \mathrm{~g} \mathrm{~L}^{-1}$ ) and manual weeding to control weeds, fertilizer ('ZA') for fertilization and an insecticide ('Tetrin'; ingredient: theta-cypermethrin $30 \mathrm{~g} \mathrm{~L}^{-1}$ ) to control insect herbivores weekly during the whole experiment, following common local management practices. We chose these insecticides and herbicides because they are most commonly used in vegetable gardens of the study area. We established 2-m drainage buffers between the plots and only sprayed when wind speed was low to avoid pesticide and fertilizer drifts between treatments.

\section{FrUIT SET, YIELD AND FARMERS REVENUES}

For each plant, we counted the total number of male and female flowers. Each flower was marked at the basis to avoid double counting. We quantified the number of fruits produced per plant, individual fruit weight, as well as fruits aborted during the ripening process. All ripe fruits (turning yellow indicates maturity) were harvested and weighted. We calculated fruit set as the ratio of the 
mean number of harvested fruits and the mean number of female flowers per subplot. Yield was calculated by multiplying the mean number of harvested fruits by the mean fruit weight for each plant and per subplot. Seeds from 10 randomly chosen fruits across plants of each subplot were counted.

We calculated net income for cucumber production based on information from two standardized questionnaires and experimental data on yield, for a standard area of $300 \mathrm{~m}^{2}$. We determined the predicted yield per plant based on the experimental results of the different treatments (with or without insect pollination, with or without weed control, with or without fertilization and with or without herbivore control). From the questionnaires ( $\mathrm{n}=30$ home garden owners), we gathered information on operational costs for cucumber production (yield per land area, and cost for land preparation, agro-chemicals and labour; Appendix S1, Supporting information; Motzke et al. 2013). For each management variable, we calculated the expected operational costs (costs for external inputs and labour). We subtracted these operational costs from the total income calculated for each management variable.

\section{POLLINATOR OBSERVATIONS AND HERBIVORY MEASUREMENTS}

The number of individuals and species of flower-visiting insects was assessed during a 5-min observation period of three random flowers per subplot, repeated three times on three different days from 9 am until 2 pm within the flowering period. Insects were identified in the field and caught for further identification in the laboratory (Michener 2000; reference collection at the Conservation and Landscape Ecology group, University Freiburg, Germany; reference collection, Agroecology, University G€ottingen, Germany) or by experts (Stephan Risch, Leverkusen; Volker Lohrmann, Berlin).

We estimated the percentage leaf damage (visible damage of leaf tissue from chewing or leaf mining) of eight individual leaves (four new leaves from the top and four old leaves from the bottom of the plant) of each of two plant individuals per treatment combination to assess overall herbivory. In addition, we counted the insect species on two plants of two separate days per treatment combination. Insect species were identified in the field to morphospecies, and only herbivorous insects were selected for the analysis.

\section{STATISTICAL ANALYSES}

We used linear mixed-effects (LME, NLME package in R; Pinheiro et al. 2007) models and generalized linear mixed-effects models (GLMM, LME4 package in R; Bates et al. 2013) for 
binary response to test the effect of the four treatments (explanatory variables: pollination, weed, fertilization and herbivory) on the yield response variables. Yield variables were the mean number of fruits, fruit set (mean number of fruits divided by the mean number of flowers, binary variable), mean fruit weight, yield (mean number of fruits multiplied by the mean fruit weight), proportion of fruits with/without seeds (binary variable coded as 'yes' or 'no' seeds) and mean number of seeds per subplot. We also included the treatment variables as nested random factors in all models to reflect the split-plot design (site/weeds/herbivory/fertilization; for full description see Appendix S2, Supporting information). The difference between the expected optimal treatment combination (insect pollination, fertilization, weed control and herbivore control) and the respective negative treatment is the yield gap related to each treatment. Best models were selected by Akaike Information Criterion (AICc) and QAICc based stepwise model selections (R-scripts on URL: http://wwwuser. gwdg.de/ - scherb1/statistics.html). We tested the effects of the treatments as well as the number of cucumber flowers (male and female) on number of bee individuals (response variable) for the insect-pollinated treatments with LME. As bee species richness and number of bee individuals were correlated (Pearson's correlation, $\mathrm{r}^{2}=0.83$ ), we present only the results for the number of bee individuals. We tested the effect of number of bee individuals and the treatment variables (explanatory variables) on fruit set with GLMM and on mean weight, mean number of fruits and yield with LME. We included number of bee individuals and number of cucumber flowers (explanatory variables; not correlated: Pearson's correlation, $\mathrm{r}^{2}=013$ ) in one model to test for their combined effects on yield (response). In addition, for the herbivore insect effects, we included the number of herbivorous species and individuals first as response variables to test for the effect of the treatments, and then as explanatory variables with fruit set and yield as response variables. We used the statistics software R, version 2.15.2, for all analyses (R Development Core Team 2013).

\section{RESULTS}

\section{RESPONSE OF YIELD VARIABLES AND ECONOMIC RETURNS PER TREATMENT}

Fruit set and yield were best explained by the model incorporating the four treatment variables (pollination, weeds, fertilization and herbivory) and the interaction between pollination and weeds (Table S1, Supporting information). The optimal treatment combination (insect pollination + weed control + fertilization + herbivore control) received highest fruit set and yield (Fig. 1a,b). Figure 1a and Table S2 (Supporting information) show the effects of the treatments on fruit set. The 95\% confidence intervals of all treatments except herbivory did not overlap with the control line, 
showing that these treatments significantly reduced fruit set (pollination: $\chi^{2}=1071.92$, d.f. $=6, P<$ 0.0001 ; weeds: $\chi^{2}=7.2$, d.f. $=7, P=0.0073$; fertilization: $\chi^{2}=4.78$, d.f. $=8, P=0.0288$; herbivory: $\chi^{2}=0.43$, d.f. $=9, P=0.5097$; Fig. 1a, Table S2, Supporting information). The strongest negative effect on fruit set was caused by the exclusion of insect pollinators (wind- and self-pollination treatment; $86 \%$ reduction compared to control), followed by no weed control ( $20 \%$ reduction) and a marginal effect of no fertilization (10\% reduction; Table S2, Supporting information, Fig. 1a).
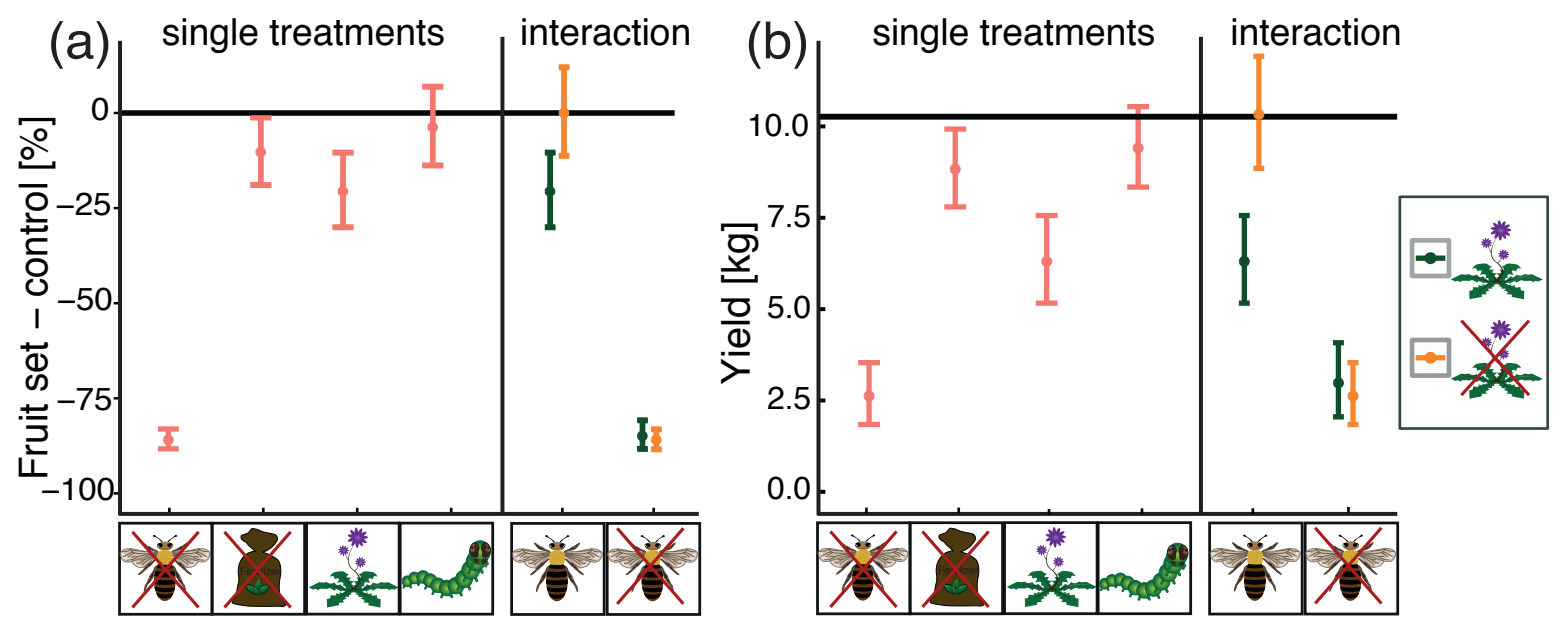

Fig. 1. Effects of single and interacting treatments on fruit set (a) and yield (b) cucumber plants, based on the predicted values of the best model. Yield is calculated for total weight $(\mathrm{kg})$ harvested from 10 cucumber plants. The reference line (horizontal black line) represents the reference, that is the expected optimal treatment combination (insect pollination, fertilization, weed control and herbivore control). Dots with error bars (95\% confidence intervals) indicate the respective negative treatment (wind- and self- pollination, without fertilization, no weed control and no herbivore control). The right part of each graph shows the interaction between the weed and pollination treatments (dark (green) dots refers to no weed control and light (yellow) for weed control). The treatment is significantly different to the expected optimal treatment combination when the error bars do not overlap the reference line.

Herbivore control did not significantly reduce fruit set ( $4 \%$ reduction). In addition, we found that without the control of weeds, fruit set was significantly reduced in the insect, but not windand self-pollination treatments (pollination* weeds: $\chi^{2}=6.8$, d.f. $=10, P=0.0092$ ). We found the same, but more pronounced pattern for yield (pollination: $\mathrm{F}=124.74$, d.f. $=73, P<0.0001$; weeds: $\mathrm{F}=16.71$, d.f. $=12, P=0.0015$; fertilization: $\mathrm{F}=9.02$, d.f. $=51, P=0.0041$; herbivory: $\mathrm{F}$ $=3.80$, d.f. $=51, P=0.063$; pollination* weeds: $\mathrm{F}=13.06$, d.f. $=73, P=0.0006$, Fig $1 \mathrm{~b}$, Table S2, Supporting information). The wind- and selfpollination treatment significantly reduced yield (yield gap of $75 \%$ compared to with insect pollination), as well as the no weed control (yield gap of 45\%) 
and no fertilization treatments (yield gap of 18\%). Yield was not influenced when herbivores were not controlled (13\% yield gap). Again, the interaction between weeds and pollinations showed that the control of weeds had only an effect in combination with the insect pollination treatment.

The effects of the four treatments on the number of fruits followed the same pattern as for fruit set and yield (Table S2, Supporting information). In contrast, mean fruit weight was significantly higher (but number of fruits much lower) for the wind- and self-pollination treatments compared to insect pollination (pollination: $\mathrm{F}=15.87$, d.f. $=63, P=0.0002$; Table S2, Supporting information). Fruits resulting from wind- and self-pollination contained no seeds or very low number of seeds [mean number of seeds for wind- and self-pollination: $21.4(\mathrm{SD} \pm 53.2)$ ] compared to insect pollination $\left(214.4(\mathrm{SD} \pm 68.8), \chi^{2}=79.35\right.$, d.f. $\left.=6, P<0.0001\right)$. The control of weeds or herbivores reduced the number of seeds after insect pollination (weeds: $F=5.96$, d.f. $=12, \mathrm{P}=$ 0.0311; herbivory: $F=8.69$, d.f. $=25, P=0.0068$, Table S2, Supporting information).

Depending on the type of management farmers can overcome yield gaps. Net income (initial income minus operational cost) from a common small-scale cucumber plantation $\left(300 \mathrm{~m}^{2}\right)$ was highest when insect pollinators had access to the cucumber flowers, with weed control and fertilization (Fig. 2). Application of insecticides to reduce herbivory had no effect on net income (Fig. 2). The operational costs exceeded the net income when pollinators were excluded, resulting in a deficit for farmers.

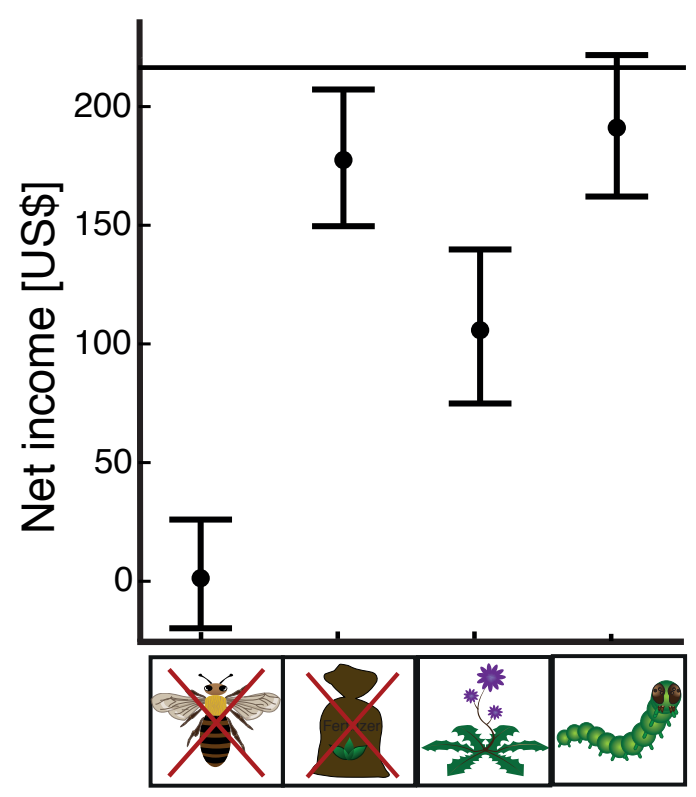

Fig. 2. Economic calculation of net income from cucumber production to local farmers. Shown are the income differences between each treatment and the control. The reference is the horizontal line set as the expected optimal treatment (insect pollination, weed control, fertilization and herbivore control) included in the farm management. 


\section{THE EFFECTS OF FLOWER-VISITING INSECTS, HERBIVOROUS INSECTS AND LEAF DAMAGE ON FRUIT} SET AND YIELD

In total, we found 37 insect species (780 individuals) visiting the cucumber flowers. The main flower visitors were bees of the families Apidae and Halictidae (Hymenoptera)comprising 964\% of all individuals found on flowers (23 species and 753 individuals; Table S3, Supporting information). The other flower visitor taxa were wasps (six individuals), flies (13 individuals), butterflies and moths (eight individuals; Table S3, Supporting information).

Bees had a significant influence on cucumber production. In case of the (open) insectpollinated plants, only the number of bee individuals and weed control significantly contributed to increase yield (bee individuals: $\mathrm{F}=39.16$, d.f. $=47, P<0.0001$; weeds: $\mathrm{F}=40.60$, d.f. $=12, P$ $<0.0001$, Fig. 3, Table S4, Supporting information). This was reflected not only in an increase in fruit set $\left(\chi^{2}=9.08\right.$, d.f. $\left.=5, P=0.0026\right)$ and mean number of fruits per subplot $(\mathrm{F}=31.03$, d.f. $=$ $48, P<0.0001)$ with increasing number of bee individuals, but also in an increase in mean fruit weight $(\mathrm{F}=11.56$, d.f. $=42, P=0.0015$, Table S4, Supporting information). The management ariables had no significant influence on the number of bee individuals, as the NULL model was the best-fitted model. But mean number of cucumber flowers per subplot significantly influenced the number of bee individuals $(\mathrm{F}=23.32$, d.f. $=50, P<0.0001)$. The number of bee individuals interacted with the number of cucumber flowers (bee individuals*cucumber flowers: $\mathrm{F}=12.88$,

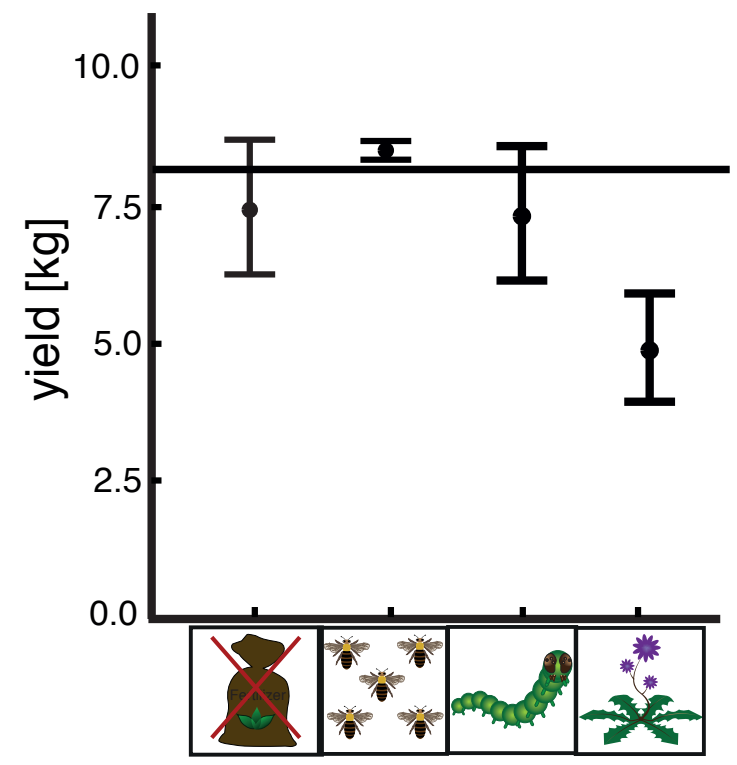

Fig. 3: Effects of the treatments 'no fertilization', 'number of bee individuals', 'no herbivore control' and 'no weed control', respectively, on yield, based on the predicted values of the best model. Graph explanation as in Fig. 1. 
d.f. $=46, P<0.0001$, Fig. 4, Table S4, Supporting information), ith numbers of bee individuals significantly increasing yield for low to medium numbers of cucumber flowers (5-15), but not for high numbers of cucumber flowers $(>20)$. We found 23 herbivorous insect species including aphids, spider mites, grasshoppers, sap-sucking true bugs, caterpillars and leaf beetles. The number of herbivorous species was reduced when pollinators were excluded $(\mathrm{F}=13.96$, d.f. $=83, P<$ 0.0001), but not influenced by the use of insecticides. Surprisingly, an increasing number of herbivorous species was positively and significantly related to yield $(\mathrm{F}=6.84$, d.f. $=72, P=0.0109$, Table S5, Supporting information). Percentage leaf damage was not influenced by the herbivore control treatment (insecticide), but was significantly higher without weed control (weeds: $F=6.27$, d.f. $=11, P=0.0293$, Table S5, Supporting information). Percentage leaf damage had no influence on yield ( $\mathrm{F}=0.25$, d.f. $=71, P=0.6166$; Table $S 5$, Supporting information).

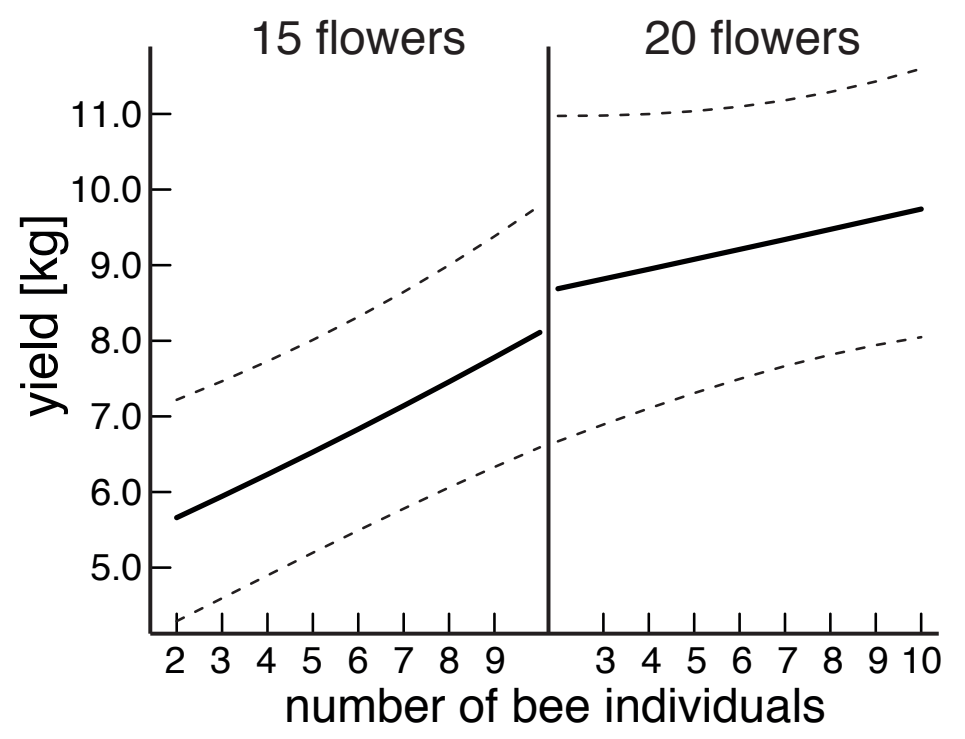

Fig. 4. Effect of the interaction between number of observed bee individuals and number of cucumber flowers on yield, based on the predicted values of the best-fitted model.

\section{Discussion}

We found that insect pollination was the most important driver for cucumber production in Indonesia. The loss of pollinators reduced yield by $75 \%$ compared to the potential maximum. Controlling weeds (yield gap 45\%) and fertilization (yield gap 18\%) further increased yield in addition to pollination services. In contrast, these treatments alone or in combination could not compensate for pollination deficits and yield without insect pollination decreased below the 
level of economical profitability (Fig. 2). This is in line with Bommarco, Kleijn \& Potts (2013) conceptualizing that yield is highest when the conditions are optimal for all yield-affecting ecosystem services or management practices and that the yield gap is driven by the least-optimal variable, in our case insect pollination. Provided that insect pollinators are present, weed control becomes the next limiting variable followed then by fertilization. As insecticide application did not influence herbivorous species, leaf damage or yield, we conclude that the excessive use of insecticides as applied in our study according to common practices is inefficient and little targeted for cucumber production in our study area.

\section{EFFECTIVE MANAGEMENT VARIABLES FOR FRUIT SET AND YIELD}

Exclusion of insect visitors strongly reduced fruit set and yield. The few fruits produced in the wind- and self-pollination treatment might have been developed after autonomous self-pollination (Gingras, Gingras \& De Oliveira 1999), transfer of pollen by wind or by insects inside the exclusion cages such as small leaf beetles or ants. These fruits were heavier, but overall yield was below economically profitable level. However, wind- and self-pollinated fruits rarely contained seeds indicating that the heavier fruits resulted from allocation of resources to the few single fruits and not from better pollination quality (i.e. higher pollen transfer). Other studies found similar results and also assumed that higher fruit size in only wind- and self-pollinated plants is caused by resource allocation (e.g. Jauker et al. 2012; Klein et al. 2014). The importance of pollination is further supported by the positive relationship of the number of flower-visiting bee individuals and yield. We found an increased number of fruits but also increased fruit weight with higher number of bee individuals, which might be due to better pollination quality. Insect pollination is known to increase fruit size and weight in some crops (e.g. Klatt et al. 2014; Klein et al. 2014). Number of flower-visiting bees was not influenced by weeds, fertilization or herbivory, but by number of cucumber flowers - that is resource availability. This suggests that farmers can enhance crop pollination, and thus cucumber production, by increasing cucumber flower resources. However, above a certain level of numbers of flowers, yield is highly independent of how many bees visit the flowers. This could be due to a high availability of pollen and, thus, better chances of successful pollen transfer even with low numbers of bees. This suggests that both high numbers of flowers and of bees are important to increase yield. However, as we only assessed the influence on bees in smallscale home gardens, research including also larger spatial scales (e.g. Veddeler, Klein \& Tscharntke 2006), considering different flower resources and habitat availability (Kohler et al. 2008; Ricketts et al. 2008) and changes from polycultures to large monocultures is urgently required. 
Weeds compete with crops, which is especially problematic in tropical areas where high temperatures and rainfall can increase weed growth (Oerke 2006). Removal of weeds substantially increased yield compared to no weeding, the latter reducing yield by $45 \%$ to unprofitable levels (Fig. 2). Without weed control, cucumber plants produced fewer flowers and fruits, and fruit weight was reduced. This may be due to competition effects for resources like light, nutrients and space or allelopathy (Belz 2007). All these factors can lead to reduced plant growth and reduced flower and fruit production (Zimdahl 1993). We applied herbicide in order to replicate the local management techniques; however, the herbicide applications close to the plants damaged leaves or even killed the crop (I. Motzke, personal observation). As this herbicide is commonly used in the study area but not targeted to the crop, additional manual weeding was necessary.

The negative effect of missing weed control was more dominant in insect-pollinated plants but negligible for only wind-and self-pollinated plants. This interaction indicates that weed control cannot compensate pollination deficits, as yield reduction was only driven by the lack of insect pollinators, but rather contributes to increasing yields in addition to insect pollination.

Flowering weeds might be expected to either distract bees from visiting cucumber flowers (Free 1993) or attract additional bees (Carvalheiro et al. 2011). However, we found no effect of weeds on the number of visiting bees. The interaction might be due to the reduced female flower production when the plant is competing with weeds, which in turn influenced the number of flower-visiting bees attracted and therefore yield in general (Fig. 4). In addition, without insect pollinators, only very few fruits were produced and therefore only limited amount of resources were used, which might have not been affected by the competition with weeds.

Fertilization increases resources for plants and thus, crop production (Jones et al. 2013). We found a positive effect of fertilization on crop yield, but this effect could not compensate the negative effects of either weed competition or pollinator loss. In cacao and almond, fertilization could not compensate for yield loss caused by pollination deficits (Groeneveld et al. 2010; Klein et al. 2014). Similar results were found in coffee and alfalfa where pollination services were more important than fertilization (Shebl et al. 2009; Boreux et al. 2013). In some wild plants, reproductive success was found to be limited by both outcross pollen and available nutrients (Caruso, Remington \& Ostergren 2005; Shi et al. 2010). Nutrient input can enhance weed growth and thus weed competition for crop plants (Di Tomaso 1995); however, we found no interaction between fertilizer and weed control. 


\section{INEFFECTIVE MANAGEMENT VARIABLE FOR FRUIT SET AND YIELD}

Herbivory by insects is one of the major problems in tropical crop production (Rao, Singh \& Day 2000). Management often includes the intensive application of insecticides, which often differs from instructions of pesticide manuals in Indonesia (I. Motzke, personal observation). We applied the insecticide according to local management practices. Even intensive spraying once a week did not influence fruit set or yield, number of herbivorous insect species or herbivory in general. This suggests that the insecticide applications were ineffective or not targeted enough. The lower number of herbivorous insect species with pollinator exclusion might be due to the pollinator exclusion cages hindering access of herbivores as well. Pest abundances were generally low in our home garden plots, which may be because natural enemies are generally more abundant in heterogeneous habitats (e.g. Thies \& Tscharntke 1999; Bianchi, Booij \& Tscharntke 2006), and therefore, pests were efficiently the small size of the sprayed areas promoted invasion of pest species from neighbouring subplots. Pollination was not influenced by insecticide application; however, we sprayed only on a small scale so visitors could have passed freely between the subplots. Our goal was not to test the effects of the insecticide on bees, which have mainly sublethal impacts such as changing the behaviour, or reducing growth rate (Gill, Ramos-Rodriguez \& Raine 2012; Henry et al. 2012; Whitehorn et al. 2012). Other studies that manipulated herbivory found that increased pollination compensated for herbivory (Strauss \& Murch 2004). The combination of enhanced pollination and herbivore control can lead to higher yield than either pollination or pest control alone (Lundin et al. 2013). In contrast to the study by Lundin et al. (2013), enhanced pollination did not alter the ability of the plants to compensate for manipulated herbivory in other studies (e.g. Barber, Adler \& Bernardo 2011; Barber et al. 2012). While we only looked at above-ground insect herbivory, other studies found that increased root herbivory can have a strong effect on cucumber performance (Barber, Adler \& Bernardo 2011). Natural pest control can also influence yield, but interactions with pollinators should be considered (e.g. Lundin et al. 2013).

\section{CONCLUSIONS AND MANAGEMENT RECOMMENDATIONS}

Our results highlight the importance of pollination services to mitigate yield gaps in cucumber, an important vegetable crop in the tropics where small-scale farmers rely on wild insect pollinators. As Indonesian home gardens support high numbers of pollinator-dependent crop species (see Kehlenbeck \& Maass 2006), this pattern should be of major importance for the yield in smallholder gardens. However, pollination services should not be considered in isolation as they are influenced 
by multiple management variables. Pest control is one aspect that must be adequately considered in farmer's management decisions. Reducing the competition of the crop with weeds and fertilization can double farmers income and are important farm management aspects. Our study plant is highly pollinator-dependent and the reported relationship of management practices and pollination services may be different for crops that are less-dependent on insect pollination. Similar studies for crops that have low to medium dependence on pollinators are urgently needed. Interestingly, insecticide applications were not effective in our study and education of farmers on how to use insecticides more targeted and sensible (e.g. Integrated Pest Management; Metcalf \& Luckmann 1994 ) is urgently needed as well as more stringent regulations and enforcement. Our results make clear how important bees are for home garden cucumber production. Sustainable recommendations for pollinator management, tailored to the regional context, need to be identified.

\section{ACKNOWLEDGEMENTS}

We deeply thank all our field assistants for their great contributions to the project, especially Akbar Saro and Sisi Boka. We are grateful for the support of Navjot Sodhi who is greatly missed; our counterpart Sahabuddin Saleh for administrative help; Stephan Risch, Volker Lohrmann, John Ascher, Dra. Erniwati and Rosichon Ubaidillah for help with insect identification and species export; Christoph Scherber and Yann Clough for advice on statistical analysis and Tim Diek€otter and two anonymous reviewers for helpful comments on the manuscript. We thank RISTEK for issuing the research permit (No.0048/EXT/SIP/FRP/SM/X/crd). The project and IM was funded by the DAAD and the German Science Foundation (DFG). TWC was funded through a PostDoctoral Fellowship of the Leuphana University L€uneburg.

\section{REFERENCES}

Andersson, G.K., Rundl€of, M. \& Smith, H.G. (2012) Organic farming improves pollination success in strawberries. PLoS ONE, 7, e31599.

Barber, N.A., Adler, L.S. \& Bernardo, H.L. (2011) Effects of above- and belowground herbivory on growth, pollination, and reproduction in ucumber. Oecologia, 165, 377-386.

Barber, N.A., Adler, L.S., Theis, N., Hazzard, R.V. \& Kiers, E.T. (2012) Herbivory reduces plant interactions with above-and belowground antagonists and mutualists. Ecology, 93, 15601570.

Bates, D., Maechler, M., Bolker, B. \& Walker, S. (2013) lme4: Linear Mixed-Effects Models Using Eigen and S4. R Package Version, Vol. 1. 1-6. Url: http://CRAN.R-project.org/ 
package $=1 m e 4$.

Belz, R.G. (2007) Allelopathy in crop/weed interactions - an update. Pest Management Science, 63, 308-326.

Bianchi, F., Booij, C. \& Tscharntke, T. (2006) Sustainable pest regulation in agricultural landscapes: a review on landscape composition, biodiversity and natural pest control. Proceedings of the Royal Society of London. Series B, Biological Sciences, 273, 1715-1727.

Bommarco, R., Kleijn, D. \& Potts, S.G. (2013) Ecological intensification: harnessing ecosystem services for food security. Trends in Ecology \& Evolution, 28, 230-238.

Bommarco, R., Biesmeijer, J.C., Meyer, B., Potts, S.G., P€oyry, J., Roberts, S.P., Steffan-Dewenter, I. \& $€$ Ockinger, E. (2010) Dispersal capacity and diet breadth modify the response of wild bees to habitat loss. Proceedings of the Royal Society of London. Series B, Biological Sciences, 277, 2075-2082.

Boreux, V., Kushalappa, C.G., Vaast, P. \& Ghazoul, J. (2013) Interactive effects among ecosystem services and management practices on crop production: pollination in coffee agroforestry systems. Proceedings of the National Academy of Sciences, 110, 8387-8392.

Bos, M.M., Veddeler, D., Bogdanski, A.K., Klein, A.M., Tscharntke, T., Steffan-Dewenter, I. \& Tylianakis, J.M. (2007) Caveats to quantifying ecosystem services: fruit abortion blurs benefits from crop pollination. Ecological Applications, 17, 1841-1849.

Caruso, C.M., Remington, D.L. \& Ostergren, K.E. (2005) Variation in resource limitation of plant reproduction influences natural selection on floral traits of Asclepias syriaca. Oecologia, 146, $68-76$.

Carvalheiro, L.G., Veldtman, R., Shenkute, A.G., Tesfay, G.B., Pirk, C.W.W., Donaldson, J.S. \& Nicolson, S.W. (2011) Natural and within-farmland biodiversity enhances crop productivity. Ecology Letters, 14, 251-259.

De Vries, F.P., Rabbinge, R. \& Groot, J. (1997) Potential and attainable food production and food security in different regions. Philosophical Transactions of the Royal Society of London. Series B: Biological Sciences, 352, 917-928.

Di Tomaso, J.M. (1995) Approaches for improving crop competitiveness through the manipulation of fertilization strategies. Weed Science, 43, 491-497.

Free, J.B. (1993) Insect Pollination of Crops. Academic Press, London.

Garibaldi, L.A., Steffan-Dewenter, I., Winfree, R., Aizen, M.A., Bommarco, R., Cunningham, S.A. et al. (2013) Wild pollinators enhance fruit set of crops regardless of honey bee abundance. Science, 339, 1608-1611. 
Gill, R.J., Ramos-Rodriguez, O. \& Raine, N.E. (2012) Combined pesticide exposure severely affects individual-and colony-level traits in bees. Nature, 491, 105-108.

Gingras, D., Gingras, J. \& De Oliveira, D. (1999) Visits of honeybees (Hymenoptera: Apidae) and their effects on cucumber yields in the field. Journal of Economic Entomology, 92, $435-438$.

Gonzalez-Varo, J.P., Biesmeijer, J.C., Bommarco, R., Potts, S.G., Schweiger, O., Smith, H.G. et al. (2013) Combined effects of global change pressures on animal-mediated pollination. Trends in Ecology \& Evolution, 28, 524-530.

Groeneveld, J.H., Tscharntke, T., Moser, G. \& Clough, Y. (2010) Experimental evidence for stronger cacao yield limitation by pollination than by plant resources. Perspectives in Plant Ecology, Evolution and Systematics, 12, 183-191.

Henry, M., Beguin, M., Requier, F., Rollin, O., Odoux, J.-F., Aupinel, P., Aptel, J., Tchamitchian, S. \& Decourtye, A. (2012) A common pesticide decreases foraging success and survival in honey bees. Science, 336, 348-350.

Jauker, F., Bondarenko, B., Becker, H.C. \& Steffan-Dewenter, I. (2012) Pollination efficiency of wild bees and hoverflies provided to oilseed rape. Agricultural and Forest Entomology, 14, $81-87$.

Jones, D.L., Cross, P., Withers, P.J.A., DeLuca, T.H., Robinson, D.A., Quilliam, R.S., Harris, I.M., Chadwick, D.R. \& Edwards-Jones, G. (2013) REVIEW: Nutrient stripping: the global disparity between food security and soil nutrient stocks. Journal of Applied Ecology, 50, $851-862$.

Kehlenbeck, K. \& Maass, B. (2006) Are tropical homegardens sustainable? Some evidence from Central Sulawesi, Indonesia. Tropical Homegardens (eds B.M. Kumar \& P.K.R. Nair), pp. 339-354. Springer, Dordrecht, the Netherlands.

Klatt, B.K., Holzschuh, A., Westphal, C., Clough, Y., Smit, I., Pawelzik, E. \& Tscharntke, T. (2014) Bee pollination improves crop quality, shelf life and commercial value. Proceedings of the Royal Society of London. Series B, Biological Sciences, 281, 20132440.

Klein, A.M., Vaissiere, B.E., Cane, J.H., Steffan-Dewenter, I., Cunningham, S.A., Kremen, C. \& Tscharntke, T. (2007) Importance of pollinators in changing landscapes for world crops. Proceedings of the Royal Society of London. Series B, Biological Sciences, 274, 303-313.

Klein, A.M., Hendrix, S.D., Clough, Y., Scofield, A. \& Kremen, C. (2014) Interacting effects of pollination, water and nutrients on fruit tree performance. Plant Biology, doi: 10.1111/ plb. 12180. 
Kohler, F., Verhulst, J., Van Klink, R. \& Kleijn, D. (2008) At what spatial scale do high-quality habitats enhance the diversity of forbs and pollinators in intensively farmed landscapes? Journal of Applied Ecology, 45, 753-762.

Kuswardhani, N., Soni, P. \& Shivakoti, G.P. (2013) Comparative energy input - output and financial analyses of greenhouse and open field vegetables production in West Java, Indonesia. Energy, $53,83-92$.

Lundin, O., Smith, H.G., Rundl€of, M. \& Bommarco, R. (2013) When ecosystem services interact: crop pollination benefits depend on the level of pest control. Proceedings of the Royal Society of London. Series B, Biological Sciences, 280, 20122243.

McGregor, S.E. (1976) Insect Pollination of Cultivated Crop Plants. Agricultural Research Service, US Department of Agriculture, Washington, DC.

Metcalf, R.L. \& Luckmann, W.H. (1994) Introduction to Insect Pest Management. Wiley. com. Michener, C.D. (2000) The Bees of the World. JHU Press, Baltimore, MD.

Motzke, I., Tscharntke, T., Sodhi, N.S., Klein, A.M. \& Wanger, T.C. (2013) Ant seed predation, pesticide applications and farmers' income from tropical multi-cropping gardens. Agricultural and Forest Entomology, 15, 245-254.

Motzke, I., Tscharntke, T., Wanger, T.C. \& Klein, A.M. (2015) Data from "Pollination mitigates cucumber yield gaps more than pesticide and fertilizer use in tropical smallholder gardens”. Dryad Digital Repository, doi:10.5061/dryad.k0p51.

Mueller, N.D., Gerber, J.S., Johnston, M., Ray, D.K., Ramankutty, N. \& Foley, J.A. (2012) Closing yield gaps through nutrient and water management. Nature, 490, 254-257.

Natawidjaja, R., Reardon, T., Shetty, S. \& TI, P. (2007) Horticultural producers and supermarket development in Indonesia. UNPAD/MSU/ World Bank. World Bank report.

Oerke, E.-C. (2006) Crop losses to pests. The Journal of Agricultural Science, 144, 31-43.

Pinheiro, J., Bates, D., DebRoy, S. \& Sarkar, D. (2007) Linear and nonlinear mixed effects models. R Package Version, 3, 57.

Potts, S.G., Biesmeijer, J.C., Kremen, C., Neumann, P., Schweiger, O. \& Kunin, W.E. (2010) Global pollinator declines: trends, impacts and drivers. Trends in Ecology \& Evolution, 25, $345-353$.

R Development Core Team (2013) R: A Language and Environment for Statistical Computing. ISBN 3-900051-07-0. R Foundation for Statistical Computing, Vienna, Austria. Url: http://www. R-project. org.

Rao, M., Singh, M. \& Day, R. (2000) Insect pest problems in tropical agroforestry systems: 
contributory factors and strategies for management. Agroforestry Systems, 50, 243-277.

Ricketts, T.H., Regetz, J., Steffan-Dewenter, I., Cunningham, S.A., Kremen, C., Bogdanski, A. et al. (2008) Landscape effects on crop pollination services: are there general patterns? Ecology Letters, 11, 499-515.

Shebl, M.A., Kamel, S.M., Abu Hashesh, T.A. \& Osman, M.A. (2009) The impact of using leafcutting bees (Megachilidae, Hymenoptera) with different fertilization treatments on alfalfa seed production. Revista de la ciencia del suelo y nutricion vegetal, 9, 134-141.

Shi, X., Wang, J.C., Zhang, D.Y., Gaskin, J. \& Pan, B.R. (2010) Pollen source and resource limitation to fruit production in the rare species Eremosparton songoricum (Fabaceae). Nordic Journal of Botany, 28, 438-444.

Strauss, S.Y. \& Murch, P. (2004) Towards an understanding of the mechanisms of tolerance: compensating for herbivore damage by enhancing a mutualism. Ecological Entomology, 29, 234-239.

Thies, C. \& Tscharntke, T. (1999) Landscape structure and biological control in agroecosystems. Science, 285, 893-895.

Tilman, D., Cassman, K.G., Matson, P.A., Naylor, R. \& Polasky, S. (2002) Agricultural sustainability and intensive production practices. Nature, 418, 671-677.

Tscharntke, T., Clough, Y., Wanger, T.C., Jackson, L., Motzke, I., Perfecto, I., Vandermeer, J. \& Whitbread, A. (2012) Global food security, biodiversity conservation and the future of agricultural intensification. Biological Conservation, 151, 53-59.

Van Rheenen, T., Elbel, C., Schwarze, S., Nuryartono, N., Zeller, M. \& Sanim, B. (2004) Encroachments on primary forests: are they really driven by despair? Land Use, Nature Conservation and the Stability of Rainforest Margins in Southeast Asia (eds G. Gerold, M. Fremerey \& E. Guhardja), pp. 199-213. Springer, Berlin, Heidelberg.

Vanbergen, A.J. \& Initiative, T.I.P. (2013) Threats to an ecosystem service: pressures on pollinators. Frontiers in Ecology and the Environment, 11, 251-259.

Veddeler, D., Klein, A.M. \& Tscharntke, T. (2006) Contrasting responses of bee communities to coffee flowering at different spatial scales. Oikos, 112, 594-601.

Wanger, T.C., Rauf, A. \& Schwarze, S. (2010) Pesticides and tropical biodiversity. Frontiers in Ecology and the Environment, 8, 178-179.

Weber, R., Faust, H., Schippers, B., Mamar, S., Sutarto, E. \& Kreisel, W. (2007) Migration and ethnicity as cultural impact factors on land use change in the rainforest margins of Central Sulawesi, Indonesia. Stability of Tropical Rainforest Margins (eds T. Tscharntke, C. 
Leuschner, M. Zeller, E. Guhardja \& A. Bidin), pp. 415-434. Springer, Berlin, Germany. Whitehorn, P.R., O'Connor, S., Wackers, F.L. \& Goulson, D. (2012) Neonicotinoid pesticide reduces bumble bee colony growth and queen production. Science, 336, 351-352.

Wissuwa, M., Mazzola, M. \& Picard, C. (2009) Novel approaches in plant breeding for rhizosphererelated traits. Plant and Soil, 321, 409-430.

Zimdahl, R.L. (1993) Fundamentals of Weed Science. Academic Press Inc., San Diego, CA. 
SUPPORTING INFORMATION

Supplementary Figure S1: Schematic PiCtURE OF THE MANAGEMENT VARIables.

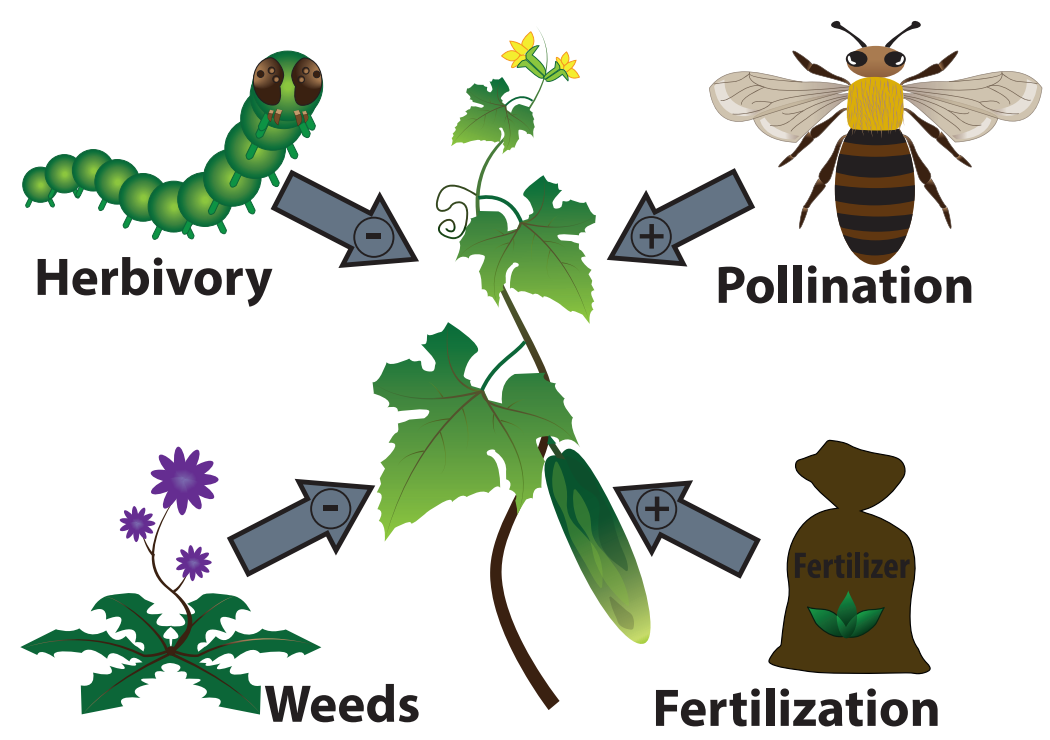

Fig. S1: Schematic picture of the most important management variables influencing cucumber yields. Factors can act additively, complementary or compensatory. 
Supplementary Figure S2: EXPERIMENTAL SPLIT-Plot DESIGN.
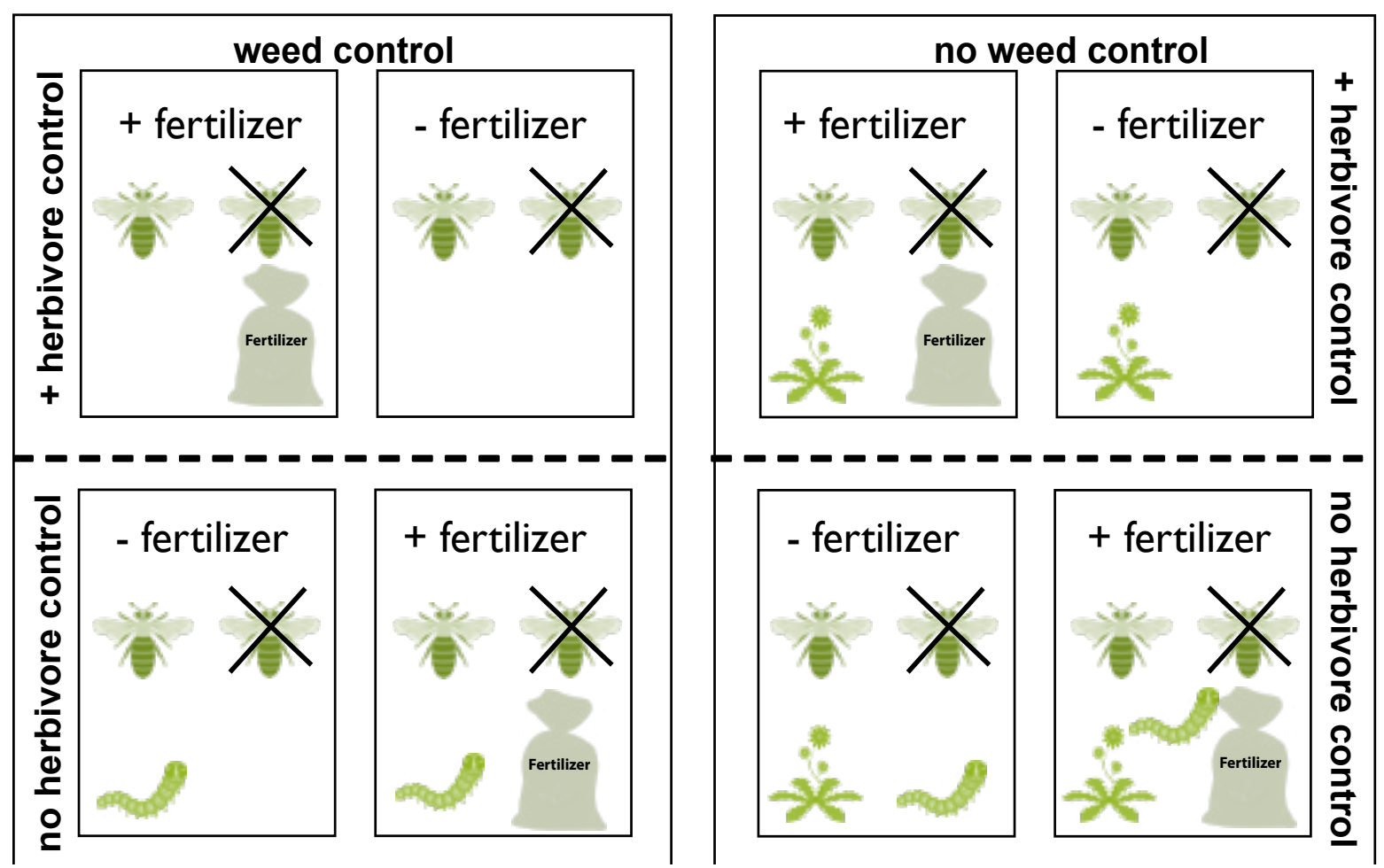

Fig. S1: Experimental split plot design of treatment applications. The area of $300 \mathrm{~m}^{2}$ in each garden was split three times into half with first weed and no weed control, then herbivore and no herbivore control, and with fertilization or without fertilization on each half resulting in eight plots. There half of the cucumber plants were left for insect pollination and half were caged to exclude insect pollinators during flowering. 


\section{Appendix A1: Calculation of NeT income}

We calculated net income based on predicted yield per plant based on the experimental results and information from two standardized questionnaires for a standard area of $300 \mathrm{~m}^{2}$ (see also Motzke et al. 2013). On a $300 \mathrm{~m}^{2}$ area, we assume 800 cucumber plants which were multiplied by the respective predicted yield for each treatment (with or without insect pollination, with or without weed control, with or without fertilization, and with or without herbivore control). From the questionnaires $(n=30)$ conducted in 2010 we gathered information on operational costs for cucumber production costs and market prices for cucumber (3,000 IDR per kg). For fertilizer and insecticide costs, we calculated a value on a per-individual plant basis, because fertilizer and insecticides are commonly applied to individual plants by hand. Costs for herbicides were calculated per area. Labor costs (for weeding, pesticide spraying and harvest) were calculated based on the time that a farmer has to spend on the plantation and the expected salary for work elsewhere. Operational costs included cost for fertilizer (70,000 Indonesian Rupiah (IDR)), insecticide (50,000 IDR), herbicide (40,000 IDR), land preparation (300,000 IDR), and labor for weeding (8 hours, 45,600 IDR), spraying ( 4 hours, 22,800 IDR), fertilization (1/2 hour, 2,850 IDR), and harvest (3 hours, 51,300 IDR) adjusted respectively to the different treatments to calculate the expected operational costs for each management variable. The operational costs were then subtracted from the income. Income was calculated by multiplying the predicted yield (in $\mathrm{kg}$ ) per plant times the number of plants possible per $300 \mathrm{~m} 2$ area (800) and the market price per $\mathrm{kg}(3,000 \mathrm{IDR})$. Values were then given in US\$ from 2010 and calculated from Indonesian Rupiah (1000 IDR = 0.113 US\$).

\section{References:}

Motzke, I., Tscharntke, T., Sodhi, N.S., Klein, A.M. \& Wanger, T.C. (2013) Ant seed predation, pesticide applications and farmers' income from tropical multi-cropping gardens. Agricultural and Forest Entomology, 15, 245-254. 


\section{APPENDIX A2: DETAILED STATISTICAL ANALYSIS}

For each plant, we measured the following yield variables: number of flowers, number of fruits, fruit set (number of fruits divided by the number of flowers), fruit weight, yield (number of fruits multiplied by the mean fruit weight), and number of seeds per fruit. These yield variables were used as response and were averaged by taking the mean of all plants within each subplot so that the subplot was the unit of (nested) replication. As fruits resulting from wind and self-pollination often contained no seeds, we used a binary variable to look at the proportion of fruits with/without seeds coded as fruits either containing seeds ("yes") or without seeds ("no") for the analysis. Due to strong and continuous rainfall during our experiments not all seven plants per treatment combination (subplot) survived, but mean number of plants per subplot were $5.7( \pm 1.3)$. However, the mean number of plants did not differ markedly across treatments (mean number of plants with: 5.9 $( \pm 1.2)$ and without: $5.5 .( \pm 1.4)$ weed control, with: $5.8( \pm 1.3)$ and without: $5.6( \pm 1.4)$ herbivore control, with: $5.8( \pm 1.3)$ and without $5.5( \pm 1.4)$ fertilization, and with: $5.6( \pm 1.4)$ and without: 5.8 ( \pm 1.2$)$ insect pollination. We included the binary (coded as "yes" and "no") treatment variables pollination, weeds, fertilization, and herbivory as fixed factors and random factors. In the models we always compared the negative (wind and self-pollination, no weed control, no fertilization, and no herbivore control) to the positive treatment combination (insect pollination, fertilization, weed control, and herbivore control), which was the expected optimal treatment combination. The difference between the optimal treatment combination and the relative negative treatment is the yield gap related to each treatment. In all models the smaller experimental units (subplots), were nested within the larger entire garden plot (site). Thus, the treatment fertilization (smallest level) was nested within herbivory, weeds and plot, which was included as random effect (site/ weeds/herbivory/fertilizer) to account for the split plot design. We used linear mixed-effects models (function lme, package "nlme" in R) for all analyses except for fruit set (binomial response) where we applied generalized linear mixed-effects models (function lmer, package "lme4" in R). We transformed response variables if necessary to meet assumptions of normality and homogeneity of variance. The response variable yield was square root transformed and number of fruits log transformed. We back-transformed all variables for visualization. 


\section{ApPendix TABLE S1: Results fOR THE MOdel SELECTION.}

Table S1: Results for the model selection for predicting fruit set and yield including all predictor variables. Shown are the best models $(\triangle \mathrm{AICc}=2)$, the NULL model, and FULL model for each response variable

\begin{tabular}{|c|c|c|c|c|c|}
\hline Explanatory variables & LL & $\mathbf{K}$ & AICc & $\Delta \mathrm{AICc}$ & wi \\
\hline \multicolumn{6}{|l|}{ Fruit set (FS) } \\
\hline poll + weeds + herb + ferti + weed $^{*}$ poll & -462.4 & 10 & 946.1 & 0.0 & 0.50 \\
\hline $\begin{array}{l}\text { poll }+ \text { weeds }+ \text { herb }+ \text { ferti }+ \text { weed }^{*} \text { poll } \\
\quad+\text { poll*ferti }\end{array}$ & -461.4 & 11 & 946.4 & 0.3 & 0.50 \\
\hline $\mathrm{FS} \sim(\text { poll }+ \text { weeds }+ \text { herb }+ \text { ferti })^{\wedge} 2$ & -460.1 & 15 & 953.2 & 7.1 & 0.00 \\
\hline NULL & -1005.7 & 5 & 2021.7 & 1075.6 & 0.00 \\
\hline \multicolumn{6}{|l|}{ Yield } \\
\hline $\begin{array}{l}\text { Yield } \sim \text { poll }+ \text { weeds }+ \text { herb }+ \text { ferti }+ \\
\text { weeds }{ }^{*} \text { poll }\end{array}$ & -527.3 & 11 & 1078.2 & 0 & 0.96 \\
\hline $\begin{array}{l}\text { Yield } \sim \text { poll }+ \text { weeds }+ \text { herb }+ \text { ferti }+ \\
\text { weeds }{ }^{*} \text { poll }\end{array}$ & -616.2 & 12 & 1258.4 & 1.3 & 0.30 \\
\hline \multicolumn{6}{|l|}{ + weeds*herb } \\
\hline Yield $\sim(\text { poll }+ \text { weeds }+ \text { herb }+ \text { ferti })^{\wedge} 2$ & -524.6 & 16 & 1084.5 & 6.3 & 0.04 \\
\hline NULL & -590.2 & 6 & 1192.8 & 114.6 & 0.00 \\
\hline
\end{tabular}

Abbreviations: fixed factors: poll= pollination, herb= herbivory, weed $=$ weeds, ferti $=$ fertilization, ${ }^{*}=$ interaction, $\wedge 2$ = all combinations of two way interactions. Parameter: $\mathrm{LL}=$ maximised log-likelihood; $\mathrm{K}$ $=$ the number of estimated parameters; AICc $=$ Akaike information criterion adjusted for small sample size; $\triangle \mathrm{AICc}=$ difference between $\mathrm{AICc}$ and the lowest $\mathrm{AICc}$ value; $\mathrm{wi}=\mathrm{AICc}$ weights 


\section{ApPendix TABLE S2: TreatMENT EFFECTS ON CUCUMBER YIELD VARIABLES.}

Table S2: Parameter estimates of the LME analysis for the effects of wind and self-pollination, weed control, fertilization, and herbivory on (a) fruit set, (b) yield, (c) mean fruit weight, (d) mean number of fruits, and (e) mean number of seeds. The models included nested random effects (site/weeds/herbivory/fertilization) for the split-plot design. The intercept represents the expected optimal treatment combination (insect pollination, fertilization, weed control and herbivore control). Included are the results from the best model resulting AICc and QAICc model selection. Response variables and significances (significance level $P<0.05$ ) are in bold.

\begin{tabular}{|c|c|c|c|c|c|c|}
\hline $\begin{array}{l}\text { response } \\
\text { variable }\end{array}$ & explanatory variables & $+/-$ & estimate & \pm SE & $\mathbf{z}$ & $P$ \\
\hline \multirow[t]{6}{*}{ (a) fruit set } & intercept & & -1.21 & 0.13 & -9.24 & $<0.0001$ \\
\hline & wind and self- pollination & - & -2.19 & 0.10 & -22.45 & $<0.0001$ \\
\hline & no weed control & - & -0.29 & 0.08 & -3.77 & 0.0002 \\
\hline & no herbivore control & & -0.05 & 0.07 & -0.70 & 0.4846 \\
\hline & no fertilization & - & -0.14 & 0.06 & -2.19 & 0.0288 \\
\hline & weeds ${ }^{*}$ pollination & & 0.36 & 0.14 & 2.61 & 0.0092 \\
\hline $\begin{array}{l}\text { response } \\
\text { variable }\end{array}$ & explanatory variables & $+/-$ & estimate & $\pm \mathrm{SE}$ & $\mathrm{t}$ & $\mathrm{P}$ \\
\hline \multirow[t]{6}{*}{ (b) yield } & intercept & & 32.15 & 1.79 & 17.92 & $<0.0001$ \\
\hline & wind and self- pollination & - & -15.94 & 1.33 & -11.97 & $<0.0001$ \\
\hline & no weed control & - & -7.02 & 1.22 & -5.77 & 0.0001 \\
\hline & no herbivore control & & -1.47 & 0.91 & -1.60 & 0.1218 \\
\hline & no fertilization & - & -2.42 & 0.91 & -2.65 & 0.0110 \\
\hline & weeds ${ }^{*}$ pollination & & 8.10 & 1.87 & 4.33 & 0.0001 \\
\hline \multirow{6}{*}{$\begin{array}{l}\text { (c) mean fruit } \\
\text { weight }\end{array}$} & intercept & & 374.19 & 25.72 & 14.55 & $<0.0001$ \\
\hline & wind and self-pollination & + & 45.63 & 20.69 & 2.21 & 0.0311 \\
\hline & no weed control & & -38.87 & 18.37 & -2.12 & 0.0559 \\
\hline & no herbivore control & & -23.71 & 14.25 & -1.66 & 0.1087 \\
\hline & no fertilization & & -10.20 & 14.23 & -0.72 & 0.4770 \\
\hline & weeds $*$ pollination & & 28.15 & 29.06 & 0.97 & 0.3364 \\
\hline \multirow{6}{*}{$\begin{array}{l}\text { (d) mean } \\
\text { number of } \\
\text { fruits (log) }\end{array}$} & intercept & & 1.33 & 0.08 & 17.32 & $<0.0001$ \\
\hline & wind and self-pollination & - & -0.82 & 0.06 & -12.79 & $<0.0001$ \\
\hline & no weed control & - & -0.34 & 0.07 & -5.03 & 0.0003 \\
\hline & no herbivore control & & -0.07 & 0.04 & -1.74 & 0.0937 \\
\hline & no fertilization & - & -0.14 & 0.04 & -3.16 & 0.0027 \\
\hline & weeds ${ }^{*}$ pollination & & 0.34 & 0.09 & 3.84 & 0.0003 \\
\hline \multirow{4}{*}{$\begin{array}{l}\text { (e) mean } \\
\text { number of } \\
\text { seeds }\end{array}$} & intercept & & 245.81 & 13.41 & 18.33 & $<0.0001$ \\
\hline & no weed control & - & -26.04 & 10.84 & -2.40 & 0.0334 \\
\hline & no herbivore control & - & -32.06 & 10.82 & -2.96 & 0.0066 \\
\hline & no fertilization & & -4.98 & 10.82 & -0.46 & 0.6478 \\
\hline
\end{tabular}

Abbreviation: ${ }^{*}=$ interaction, $\mathrm{SE}=$ standard error, $+/=$ - direction of effect 


\section{SUPPLEMENTARY TABLE S3: LIST OF INSECTS FOUND ON CUCUMBER FLOWERS}

\begin{tabular}{|c|c|c|c|}
\hline Bee species & individuals & Butterfly species & individuals \\
\hline Megachile aterrima Smith & 1 & Lepidoptera sp.2 & 5 \\
\hline Amegilla sp.2 & 3 & Lepidoptera sp.3 & 2 \\
\hline Amegilla sp.1 & 111 & Lepidoptera sp.4 & 1 \\
\hline Apis cerana Fabricius & 36 & Wasp species & \\
\hline Apis dorsata binghami Cockerell & 3 & Polistes stigma (Fabricius) & 2 \\
\hline Lipotriches philippinensis (Cockerell) & 2 & Rhynchium sp. 1 & 3 \\
\hline Ceratina cognata Smith & 63 & Camsomeriella sp.7 & 1 \\
\hline Ceratina rugifrons Smith & 45 & Fly species & \\
\hline Ceratina sp.1 & 15 & Syrphidae sp.1 & 1 \\
\hline Ceyalictus sp. 1 & 1 & Syrphidae sp.2 & 1 \\
\hline Lasioglossum halictoides (Smith) & 32 & Syrphidae sp.3 & 1 \\
\hline Lasioglossum vagans (Smith) & 49 & Syrphidae sp.4 & 1 \\
\hline Nomia formosa Smith & 8 & Syrphidae sp.5 & 3 \\
\hline Nomia fulvata (Fabricius) & 268 & Tachinidae sp. 1 & 1 \\
\hline Geniotrigona incisa (Sakagami and Inoue) & 5 & Miridae sp.1 & 3 \\
\hline Gnathonomia thoracica Smith & 14 & Fannidae sp.1 & 2 \\
\hline Homalictus vechti Pauly & 4 & & \\
\hline Patellapis celebensis (Blüthgen) & 5 & & \\
\hline Ceratina unimaculata Smith & 2 & & \\
\hline Tetragonula sp.1 & 2 & & \\
\hline Thyreus nitidulus (Fabricius) & 3 & & \\
\hline Xylocopa aestuans (Linnaeus) & 69 & & \\
\hline Xylocopa dejeanii Lepeletier & 12 & & \\
\hline
\end{tabular}




\section{APPENDIX TABLE S4: EFFECTS OF TREATMENTS ON BEES AND OF BEES ON FRUIT SET AND YIELD.}

Effect of the treatments and number of bee flower visitors on (a) fruit set, (b) yield, (c) number of fruits, and (d) mean fruit weight. Effects of number of cucumber flowers on (e) the number of bee flower visitors and effects of number of cucumber flowers and the number of bee flower visitors on (f) yield. The models included nested random effects (site/weeds/ herbivory/fertilization) for the split-plot design. Included are the results from the best model resulting AICc and QAICc model selection. Response variables and significances (significance level $P<0.05)$ are in bold.

\begin{tabular}{|c|c|c|c|c|c|c|}
\hline $\begin{array}{l}\text { response } \\
\text { variable }\end{array}$ & explanatory variables & $+/-$ & estimate & $\pm \mathrm{SE}$ & $\mathbf{z}$ & $\mathbf{P}$ \\
\hline \multirow[t]{3}{*}{ (a) fruit set } & intercept & & -1.39 & 0.15 & -9.17 & $<0.0001$ \\
\hline & bee individuals & + & 0.03 & 0.01 & 2.79 & 0.0054 \\
\hline & no weed control & - & -0.29 & 0.08 & -3.45 & 0.0006 \\
\hline response variable & explanatory variables & $+/-$ & estimate & $\pm \mathrm{SE}$ & $\mathrm{t}$ & $\mathrm{P}$ \\
\hline \multirow[t]{4}{*}{ (b) yield (sqrt) } & intercept & & 25.99 & 2.61 & 9.96 & $<0.0001$ \\
\hline & bee individuals & + & 0.56 & 0.23 & 2.44 & 0.0184 \\
\hline & no weed control & - & -11.64 & 2.30 & -5.06 & 0.0003 \\
\hline & bee individuals*weeds & & 0.52 & 0.27 & 1.94 & 0.0583 \\
\hline \multirow{5}{*}{$\begin{array}{l}\text { (c) number of } \\
\text { fruits (log) }\end{array}$} & intercept & & 2.40 & 0.35 & 6.92 & $<0.0001$ \\
\hline & bee individuals & + & 0.06 & 0.03 & 2.02 & 0.0485 \\
\hline & no weed control & - & -1.39 & 0.30 & -4.69 & 0.0005 \\
\hline & no fertilization & - & -0.32 & 0.15 & -2.09 & 0.0416 \\
\hline & bee individuals*weeds & & 0.06 & 0.03 & 1.89 & 0.0655 \\
\hline \multirow{5}{*}{$\begin{array}{l}\text { (d) mean fruit } \\
\text { weight }\end{array}$} & intercept & & 301.69 & 27.27 & 11.06 & $<0.0001$ \\
\hline & bee individuals & + & 6.10 & 1.86 & 3.27 & 0.0021 \\
\hline & no fertilization & & 20.35 & 18.83 & 1.08 & 0.2859 \\
\hline & no weed control & & -11.37 & 19.45 & -0.58 & 0.5696 \\
\hline & fertilization*weeds & & -49.11 & 26.81 & -1.83 & 0.0741 \\
\hline \multirow{2}{*}{$\begin{array}{l}\text { (e) bee } \\
\text { individuals (sqrt) }\end{array}$} & intercept & & 1.00 & 0.22 & 4.62 & $<0.0001$ \\
\hline & number flowers & + & 0.05 & 0.01 & 4.83 & $<0.0001$ \\
\hline \multirow[t]{4}{*}{ (f) yield (sqrt) } & intercept & & 3.36 & 2.70 & 1.24 & 0.2205 \\
\hline & bee individuals & + & 1.69 & 0.35 & 4.83 & $<0.0001$ \\
\hline & number flowers & + & 1.28 & 0.17 & 7.59 & $<0.0001$ \\
\hline & bee individuals*number flowers & & -0.07 & 0.02 & -3.59 & 0.0008 \\
\hline
\end{tabular}

Abbreviation: ${ }^{*}=$ interaction, $\mathrm{SE}=$ standard error, $+/=$ direction of effect 


\section{APPENDix TABLE S5: EFFECTS OF HERBIVORY VARIABLES}

Effects of (a) percentage leaf damage and (c) number of herbivorous species on yield. Effects of management variables on (b) percentage leaf damage and (d) herbivorous species. The models included nested random effects (site/weeds/herbivory/fertilization) for the split-plot design. Included are the results from the best model resulting AICc model selection. Response variables and significances (significance level $P<0.05$ ) are in bold.

\begin{tabular}{|c|c|c|c|c|c|c|}
\hline $\begin{array}{l}\text { response } \\
\text { variable }\end{array}$ & explanatory variables & $+/-$ & estimate & $\pm \mathrm{SE}$ & $\mathbf{t}$ & $P$ \\
\hline \multirow{2}{*}{$\begin{array}{l}\text { (a) yield } \\
\text { (sqrt) }\end{array}$} & intercept & & 21.22 & 1.69 & 12.58 & $<0.0001$ \\
\hline & \%leaf damage & & -0.10 & 0.20 & -0.50 & 0.6166 \\
\hline \multirow{4}{*}{$\begin{array}{l}\text { (b) \% leaf } \\
\text { damage } \\
\text { (logit) }\end{array}$} & intercept & & -3.57 & 0.30 & -12.10 & $<0.0001$ \\
\hline & wind- and self-pollination & & -0.29 & 0.15 & -1.92 & 0.0577 \\
\hline & no fertilization & & -0.28 & 0.15 & -1.88 & 0.0670 \\
\hline & no weed control & + & -0.71 & 0.28 & -2.50 & 0.0293 \\
\hline \multirow{2}{*}{$\begin{array}{l}\text { (c) yield } \\
\text { (sqrt) }\end{array}$} & intercept & & 18.73 & 1.77 & 10.58 & $<0.0001$ \\
\hline & herbivorouse species & + & 0.18 & 0.07 & 2.61 & 0.0109 \\
\hline & intercept & & 2.78 & 0.17 & 16.66 & $<0.0001$ \\
\hline $\begin{array}{l}\text { herbivorouse } \\
\text { species }\end{array}$ & wind- and self-pollination & - & -0.57 & 0.15 & -3.74 & 0.0003 \\
\hline
\end{tabular}




\section{Chapter 3}

\section{BeE MANAGEMENT ON MULTIPLE SPATIAL SCALES IS NEEDED TO ENHANCE CROP YIELD IN TROPICAL HOMEGARDENS}

Authors: Iris Motzke, AleXandra-Maria Klein, Shahabuddin Saleh, Thomas C. Wanger and Teja TscharntKe 


\section{Abstract}

Pollinators act on different spatial scales but still little is known how the combination of bee management from farm to landscape scales contribute to crop pollination and yield-gap reduction. We analyse factors on three spatial scales driving bee abundance and their effects on cucumber production in homegardens. Further, we test for differences in the bee responses in respect to functional traits.

Yield increased significantly with increasing number of flower-visiting bees, with solitary bees being the most abundant visitors. Bee loss of $50 \%$ translated into a $47 \%$ income decline.

Bees were affected on multiple spatial scales. On the (1) homegarden scale, the percentage of homegarden flower cover best predicted pollinator attraction, if, on the (2) adjacent-habitat scale (200m radius), a higher percentage of homegardens (at least 20\%) surrounded the study homegarden. On the (3) landscape scale (0-2200m), bees increased significantly closer to the forest, driven by small bees. Homegardens with $50 \%$ flower cover, surrounded by $50 \%$ homegardens and $<100 \mathrm{~m}$ from the forest generated an at least nine-fold higher income compared to homegardens with low flower cover (15\%) and being isolated from the forest (>1500m).

Farmers therefore need to adjust bee management on three spatial scales to reduce crop yield gaps.

Keywords: adjacent-habitat, bee pollination, Cucumis sativus, flower cover, Indonesia, net income 


\section{INTRODUCTION}

Insect pollinators provide an important service for crop production (Klein et al. 2007); however this service is at risk (Aizen et al. 2008) due to declining bee populations in many parts of the world (Ricketts 2004; Potts et al. 2007; Gonzalez-Varo et al. 2013). Especially in tropical areas, where farmers depend mostly on wild, non-managed, bees (Hoehn et al. 2008; Klein et al. 2003a), landuse change impacts on wild pollinators and pollination services are not well understood. Research aiming to disentangle drivers of diversity and flower visitation of wild bees on the landscape and local scale is required (Tscharntke et al. 2005, 2012).

Wild bees can be influenced by multiple determinants on the landscape scale through i) isolation from natural habitat (landscape scale) and ii) availability of quality habitat in the direct neighbourhood (adjacent-habitat scale), and on the local farm or homegarden scale through iii) local management practices and availability of alternative flower resources (Kremen et al. 2007; Carvalheiro et al. 2011; Kennedy et al. 2013).

The isolation from natural habitat negatively affects bee visitation, richness and stability that usually decrease with increasing distance from the nearest forest habitat (Klein et al. 2003a; Ricketts et al. 2008; Carvalheiro et al. 2010; Garibaldi et al. 2011). However, not all bee species are equally affected by forest distance (Greenleaf and Kremen 2006). For example, small bees might respond to landscapes at finer scales than large bees (Greenleaf et al. 2007; Klein et al. 2008; Benjamin et al. 2014). The amount of natural or semi-natural habitat adjacent to the crops can influence the available species pool (Tscharntke et al. 2012) and might be even more important than distance to natural habitat (Schüepp et al. 2014). Natural or semi-natural habitat provides key food and nesting resources for wild bees (Tscharntke et al. 2005; Kremen et al. 2007), while homegardens can act as both sink and source habitat for bees depending on the amount of food and nesting resources offered (Goulson 2003; Smith et al. 2006; Cussans et al. 2010; Samnegård et al. 2011).

On a smaller scale, farm management can have a great influence on wild bees and pollination services mostly in interaction with landscape factors (e.g., Rundlöf et al. 2008; Williams and Kremen 2007; Concepcion et al. 2012), but being sometimes more important than landscape effects (Jha and Vandermeer 2009; Kennedy et al. 2013). Pollinator populations can be attracted through high flower resources of both crop and non-crop flowers on the farm or in the homegarden (e.g., Kim et al. 2006; Holzschuh et al. 2008; Batáry et al. 2011).

So far, most studies have separately looked at either the landscape (e.g., Ricketts et al. 2008; Krishnan et al. 2012) or farm scale (e.g., Kremen et al. 2002, 2004), when effects on pollinators 
were studied. In addition, few studies have included the relation of pollinator visitation to fruit set and yield, which is the final ecosystem service providing direct benefits to farmers (e.g., Holzschuh et al. 2007; Rundlöf et al. 2008). Patterns of bee-flower-yield interactions are usually complex and most habitat and landscape variables do not act separately but are influenced by each other (Brittain et al. 2010; Andersson et al. 2013; Schüepp et al. 2014). Further, differences between regions (Kennedy et al. 2013) and pollinator guilds (Greenleaf and Kremen 2006; Rundlöf et al. 2008) play a role. Scale-dependency may change between solitary and social bees (e.g., Klein et al. 2003b) and with body size (e.g., Klein et al. 2008). Disentangling the interacting effects on different spatial scales in direct relation to crop yield is necessary to provide better cost-benefit analyses of landscape and farm management practices (e.g., Greenleaf and Kremen 2006; Carvalheiro et al. 2010; Boreux et al. 2013; Schüepp et al. 2014).

Here, we aim to disentangle the interactive effects of bee management on multiple spatial scales (Fig. 1). Specifically, we determine how homegarden, adjacent-habitat and landscape scale management influences the number of wild bee individuals visiting cucumber flowers and their effects on yield of small-scale farmers. We assess the role of the amount of adjacent homegardens as managed habitat for pollinators (in addition to forest as natural habitat), with bee population responses hypothesized to depend on bee sociality and body size.

\section{MeTHODS}

\section{STUDY AREA AND CROP SYSTEM}

Our study was conducted in Lore Utara (Napu valley), Central Sulawesi, Indonesia. The valley is located between Palu city and Poso regency at an elevation of 1100-1200m a.s.l. with mean annual temperatures of $24.0 \pm 0.16^{\circ} \mathrm{C}$. The area comprises a mosaic of villages with species-rich traditional homegardens embedded in rice paddies, vegetable gardens, and cacao agroforests directly bordering the tropical rainforest of the Lore Lindu National Park. Due to high human immigration and a growing human population, illegal deforestation and pollution from pesticide use are increasingly important issues for the environment (Maertens et al. 2002; Kehlenbeck 2007). The area is well known for their diverse traditional homegardens (Kehlenbeck and Maas 2006), which provide heterogeneous habitats (with blooming patches, fallows, woody plants and undisturbed soils; Kehlenbeck 2007), offering food and nesting resources for bees as well as a (general) refuge from pollution and land conversion. Cucumbers (Cucumis sativus, L.) are of major importance both 
for self-consumption and a source of income (Natawidjaja et al. 2007). Cucumbers have male and female flowers and depend on animal pollination (Free 1993; McGregor 1976). The time of flowering in one homegarden is between two to three weeks per total growing period (2-2.5 months).

\section{THE EXPERIMENTAL DESIGN INCLUDING POLLINATOR OBSERVATION AND LANDSCAPE CHARACTERIZATION}

We selected 13 homegardens along a gradient of forest distance ranging from 5 to $2200 \mathrm{~m}$. The sites where chosen to be in an area of $4000 \mathrm{~m}$ radius with a minimum distance of $500 \mathrm{~m}$ between the sites (see Fig. S1 in electronic supplementary material).

In each homegarden, we planted cucumber plants in a split plot design of eight subplots of 7 plants each in an area of $300 \mathrm{~m}^{2}$. Plant survival was recorded resulting due to strong and continuous rainfall in 3-7 plants per subplot. In each subplot we applied different combinations of commonly used fertilizers, herbicides (combined with manual weeding) and insecticides to test the effect of management practices on cucumber plants (see Motzke et al. 2014 for details). We accounted for treatment effects in the statistical models (see below). We counted the male and female flowers and the fruits of each plant and measured the weight of each fruit. Yield was calculated as the product of mean fruit weight per plant and the number of fruits per plant.

In each subplot we observed insect flower visitors on 3 days between 9 and 12 am for a 5 min interval each. The observed insects were caught after the observation and identified in the field or laboratory (Michener 2000; reference collections at the Conservation and Landscape Ecology Group, University of Freiburg, Germany and the Agroecology group, University of Göttingen, Germany) and by experts (Stephan Risch, Leverkusen). As body size classification of bees we used the inter-tegular span (large $>2 \mathrm{~mm}$, small $\leq 2.0 \mathrm{~mm}$; Cane 1987, Table S2). Bees were classified as social bees (species from the genus Apis, Geniotrigona and Tetragonula) or mainly solitary bees (including bees from the family Halictidae where some varying forms of social behaviour do occur, e.g., Wcislo et al. 1993, but information on sociality are lacking for almost all of the observed species; Table S2).

Area of the flower cover per homegarden was estimated once as the mean cover of flowering plants in five $2 \times 2$ meter points of each homegarden. To characterize the landscape adjacent to the study homegarden, we visually estimated the area of homegarden in a 200-meter radius around the study homegardens. Distance to the forest was measured with a GPS (Garmin Oregon 550t, Garmin International Inc.) to determine the nearest point of the forest margin. 


\section{STATISTICAL ANALYSES}

We used variables on three spatial scales that may be important for bee management. On the finest scale (homegarden scale) we selected the percentage of flower cover per homegarden (hereafter referred to as \% flower cover) because it should provide resources attracting bees (Garibaldi $e t$ al. 2011). On the second scale (adjacent-habitat scale), we selected the percentage of homegarden area (hereafter referred to as $\%$ homegarden area) in a $200 \mathrm{~m}$ radius surrounding the studied homegarden as a measure of potential nesting and flower resources available for bees (Samnegård et al. 2011). On the third and largest scale (landscape scale), we included the distance to the rainforest (0$2200 \mathrm{~m}$; hereafter referred to as forest distance) as measure of habitat isolation in the analysis. The variable forest distance was log-transformed as the relationship between forest distance and the response variable was non-linear. The variables $\%$ homegarden area and forest distance correlated (Pearson's correlation: $\left.\mathrm{r}^{2}=0.56\right)$, but the variance inflation factor $(\mathrm{VIF}=2.3)$ was below the value recommended $(\mathrm{VIF}<3)$ to reduce the chance of collinearity (Zuur et al. 2010). All other variables showed no correlation (Table S1).

We used the number of bee individuals and not bee species richness as response variable in our models, because the two variables were highly correlated (Pearson's correlation, $t=15.24$, d.f. $=101$, $\mathrm{P}<0.0001, \mathrm{r} 2=0.75$, Fig. S2). We chose the number of bee individuals (sum of 3 observations) as the more robust variable as we cannot make unambiguous conclusions on the role of species richness in this study. For the effect of bee individuals (sqrt-transformed) on yield we used a linear mixedeffects (LME, "nlme" package; Pinheiro et al. 2009) models including the number of cucumber flowers as a covariate and the split plot treatments (garden/ weed control/ fertilization) nested as random effects as required for a split plot analysis (for more detail see Motzke et al. 2014). We tested the effect of scale variables (\% flower cover, \% homegarden area, and forest distance) on the overall number of bee individuals, only solitary bee individuals, and only small or only large bee individuals (response variables, sqrt-transformed) also with LME. The explanatory variables were standardised by subtracting the mean and dividing it by two times the standard deviation to compare model estimates (Gelman 2008).

We used Akaike's information criterion (AICc, corrected for small sample size) stepwise model selection to determine the best-fitted model (R-script on URL: http://wwwuser.gwdg. $\mathrm{de} / \sim \operatorname{cscherb} 1 /$ statistics.html).

For the net income calculations, we predicted the number of bee individuals for low and high values across the three scale variables (10\% and 50\% flower cover, $10 \%$ and $50 \%$ homegarden 
area, and $40 \mathrm{~m}$ and $1500 \mathrm{~m}$ forest distance), resulting in eight possible predicted numbers of bee individuals. We then used these estimated number of bee individuals to predict yield (see model above) and net income. The latter was calculated based on a $300 \mathrm{~m}^{2}$ area (with 800 cucumber plants) and the market price per $\mathrm{kg}(0.34 \$)$ per one cucumber growing period. Values are given in US\$ with the exchange rate of 0.113 US\$ per 1,000 Indonesian Rupiah. We subtracted operational costs (total $65.83 \$$ ) for fertilizer, insecticide, herbicide, land preparation, and labour (Motzke et al. 2014).

All analyses were performed in R, version 2.15.2 (R Development Core Team 2013).

(5.65\$), herbicide (4.52\$), land preparation (33.90\$), and labor (weeding, spraying, and harvest; 13.85\$). All analyses were performed in $\mathrm{R}$, version 2.15.2 (R Development Core Team 2013)

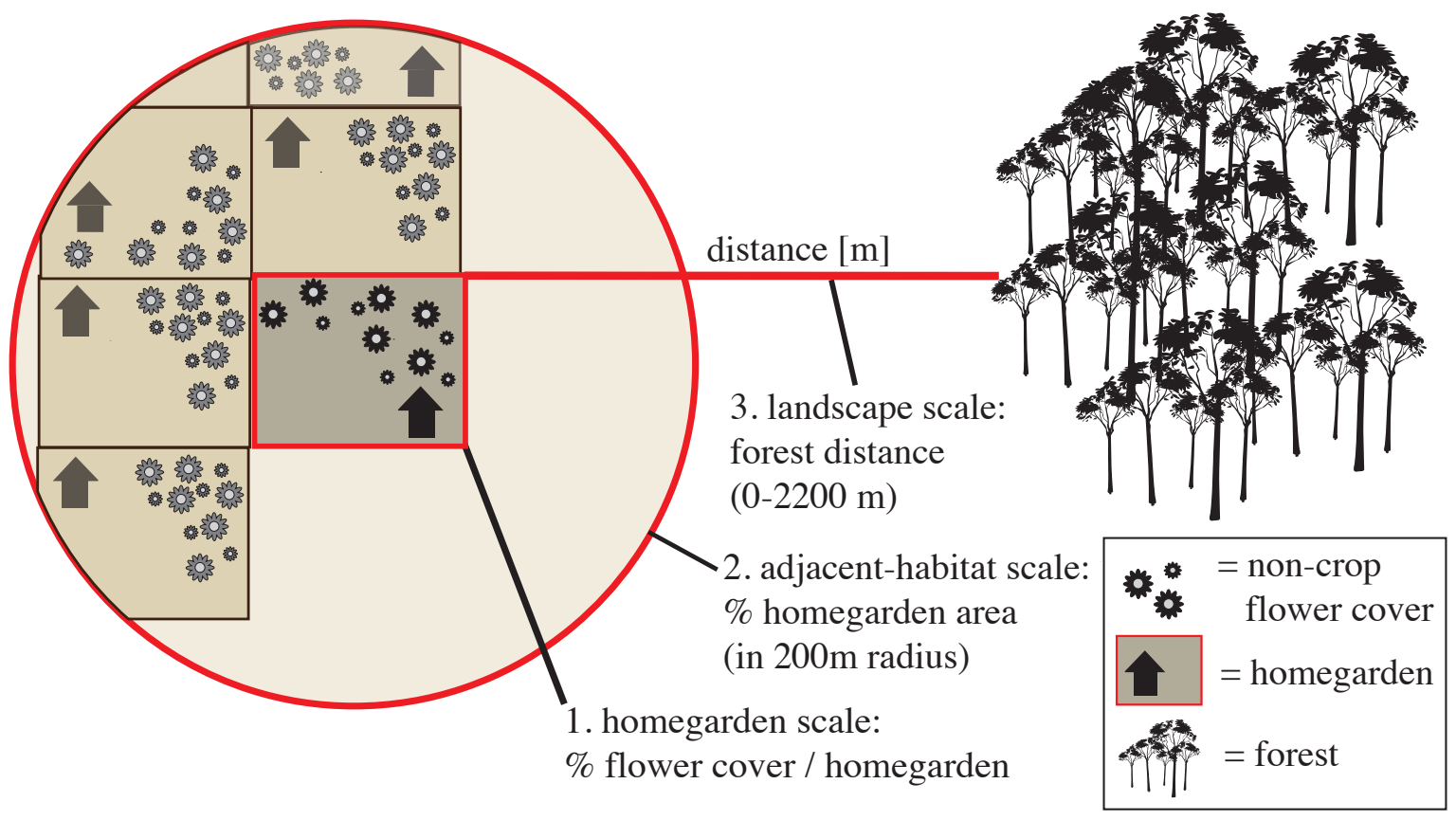

Fig. 1 Schematic figure of the three spatial scales assessed in this study. Spatial scales increase from the homegarden, to the adjacent-habitat, and to landscape scale. . 


\section{RESUlTS}

\section{Pollinator COMMUNity}

During our observations we found 37 insect species $(n=780)$ including mainly bees of the families Apidae and Halictidae ( $\mathrm{n}=753$ ) comprising $96.4 \%$ of all individuals (23 species, Table S2). The most abundant bee group were solitary bees (92\%) with Nomia fulvata (Fabricius), Amegilla sp.1, and Xylocopa aestuans (Linnaeus) as the most abundant species (36\%, 15\%, and 13\% of all bees, respectively). We found five social bee species (8\%) with Apis cerana Fabricius being the main social bee species $(60 \%$ of social bee individuals) visiting cucumber flowers.

\section{CORRELATING BEES AND YIELD}

Yield increased significantly with increasing number of flower-visiting bee individuals $(\mathrm{F}=39.38$, d.f. $=48, P<0.0001$, Fig. 2). Yield is predicted to increase by $59 \%$ when visits doubled from 7 to 14 bees per plant and $5 \mathrm{~min}$ observation period ( $0.66 \mathrm{~kg}$ to $1.1 \mathrm{~kg}$ per plant). This also means that losing $50 \%$ of bees translates into a net income decline of $47 \%$.

\section{EFFECTS ON BEES ON THREE SPATIAL SCALES}

The best model explaining the number of bee individuals included the variables $\%$ flower cover, $\%$ homegarden area, forest distance, and the interaction of flower cover * homegarden area (Table 1). On the first (smallest) and second spatial scale (garden and adjacent-habitat scale) \% flower cover ( $>40 \%$ ) had a significant greater effect on the number of bee individuals when the $\%$ homegarden area was also higher (>20\%; Fig. 3(b)). The interaction had the highest estimate value and, thus, the strongest influence of all variables on number bee individuals. In addition, homegardens with close proximity to the forest $(-50 \%$ reduction in the first $100 \mathrm{~m})$ had significantly higher numbers of bee individuals visiting the flowers, following a logarithmic relationship (Fig. 3(a), Table 1).

Net income was predicted to increase with higher numbers of bee flower visitors, which can be achieved with increased \% of flower cover, but only if the homegarden was surrounded by homegardens and/or was located close to the forest (Table 2). Thus, highest income due to highest number of bee individuals was predicted in a setting with 50\% adjacent homegarden area, close $(50 \mathrm{~m})$ to the forest and a high flower cover $(50 \%)$. This can result in a maximum income of about 180 \$ compared to an income below 20 \$ with only low flower cover $(15 \%)$ and further $(>1500 \mathrm{~m})$ away from the forest (Table 2). 


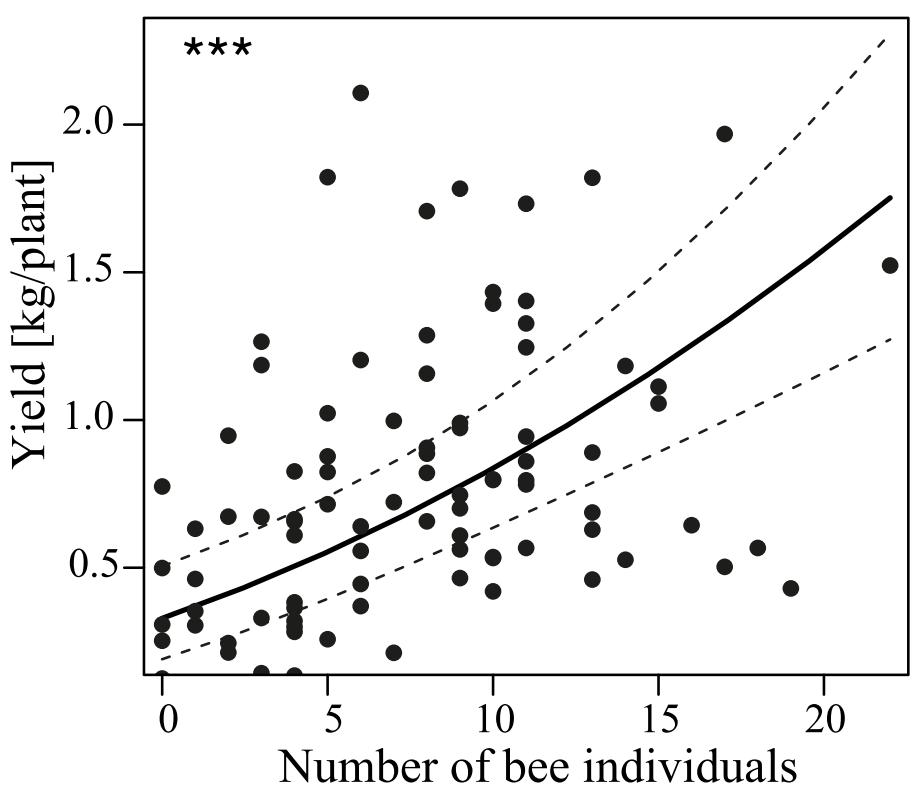

Fig. 2 Significant relationship $(P<0.0001)$ of yield $(\mathrm{kg}$ harvested per cucumber (Cucumis sativus L.) plant) and number of bee individuals visiting the flowers. The black line displays the predicted values from the model and the dashed lines $95 \%$ confidence intervals. Original values are shown as dots. Statistical significance is represented by asterisk symbols for $P$-values below $0.0001^{* * *}$ )

(a)

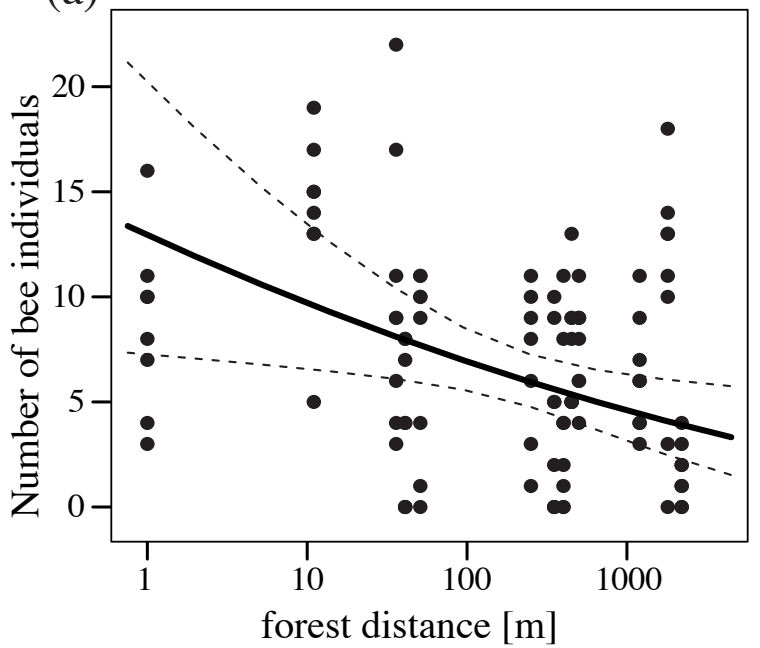

(b)

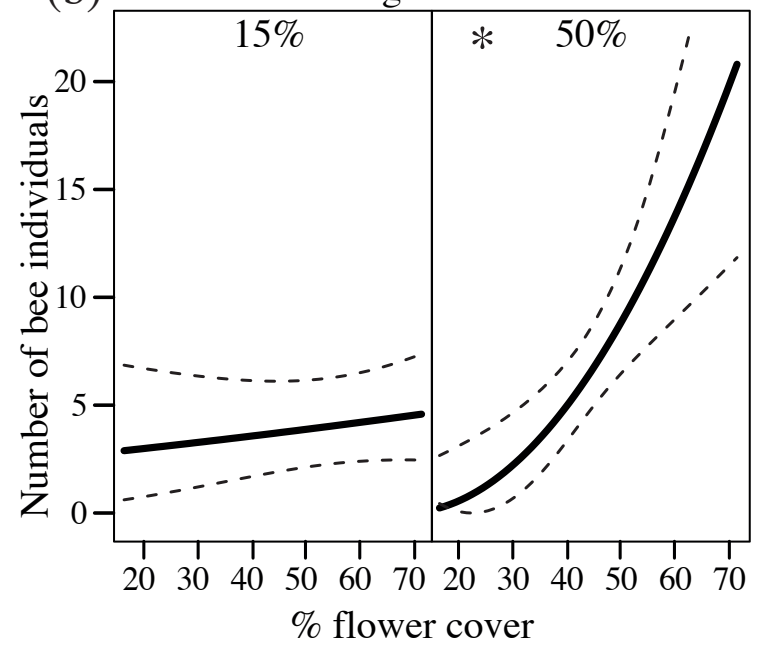

Figure 3: Relationship of number of bee individuals and the three scale variables included in the best model. The black line displays the predicted values from the model and the dashed lines 95\% confidence intervals. Statistical significance is represented by asterisk symbols for P-values below $0.05\left(^{*}\right)$. (a): The effect of number of forest distance (log scale) on number of bee individuals. Observed number of bee individuals is shown as dots. (b): Effect of the interaction of $\%$ flower cover and the $\%$ homegarden area on the number bee individuals.

Table 1: Parameter estimates of the LME analysis for the effects of \% flower cover per homegarden, \% homegarden area, and forest distance on (a) number of bee individuals, (b) 
number of solitary bee individuals, (c) number of small bee individuals, and (d) number of large bee individuals visiting the cucumber flowers. The models included nested random effects (site/weeds/herbivory/fertilization) for the split-plot design. Included are the results from the best model resulting step AICc model selection.

\begin{tabular}{|c|c|c|c|c|c|}
\hline $\begin{array}{l}\text { response } \\
\text { variables }\end{array}$ & explanatory variables & estimate & $\pm \mathrm{SE}$ & $\mathbf{t}$ & 1 \\
\hline \multirow[t]{5}{*}{ (a) all bees } & intercept & 2.49 & 0.13 & 19.37 & $<0.001$ \\
\hline & $\%$ flower cover & 0.88 & 0.40 & 2.18 & 0.061 \\
\hline & $\%$ homegarden & 1.63 & 0.40 & 4.02 & 0.004 \\
\hline & forest distance & -1.00 & 0.41 & -2.45 & 0.040 \\
\hline & $\%$ flower cover ${ }^{*} \%$ homegarden & 2.23 & 0.84 & 2.64 & 0.030 \\
\hline
\end{tabular}

AICc full/minimal: 316.0/311.6

\begin{tabular}{llrrrr}
\hline (b) solitary bees & intercept & 2.38 & 0.13 & 17.89 & $<0.001$ \\
& \% flower cover & 1.45 & 0.42 & 3.44 & 0.009 \\
& \% homegarden & 0.84 & 0.42 & 2.02 & 0.078 \\
& forest distance & -1.08 & 0.42 & -2.56 & 0.034 \\
& \% flower cover\% homegarden & 1.83 & 0.88 & 2.09 & 0.070
\end{tabular}

AICc full/minimal: $315.6 / 311.1$

\begin{tabular}{llrrrr}
\hline (c) small bees & intercept & 1.99 & 0.13 & 14.91 & $<0.001$ \\
& \% homegarden & 0.91 & 0.44 & 2.08 & 0.068 \\
& \% flower cover & 0.86 & 0.29 & 2.93 & 0.017 \\
& forest distance & -0.99 & 0.43 & -2.28 & 0.049
\end{tabular}

AICc full/minimal: $302.2 / 298.4$

\begin{tabular}{llrrrr}
\hline (d) large bees & intercept & 1.15 & 0.15 & 7.62 & $<0.001$ \\
& \% flower cover & -0.51 & 0.33 & -1.58 & 0.148 \\
& \% homegarden & 0.93 & 0.48 & 1.94 & 0.084 \\
& \% flower cover\% homegarden & 2.24 & 0.97 & 2.31 & 0.047
\end{tabular}

AICc full/minimal: $227.3 / 222.2$

Abbreviation: ${ }^{*}=$ interaction, $\mathrm{SE}=$ standard error, $+/=$ direction of effect, full $=$ the AICc of the full model (including all explanatory variables and two-way interactions), minimal= the AICc of the best model resulting AICc model selection

\section{BEE TRAITS SUCH AS BODY SIZE AND SOCIALITY}

\section{SOCIAL VS SOLITARY BEES}

Yield also significantly increased when we included only the number of solitary bee individuals in the analysis $(\mathrm{t}=8.19$, d.f. $=48, P<0.001)$, but not the number of social bee individuals $(\mathrm{t}=1.22$, d.f. $=48, P=0.228)$.

Solitary bee individuals were influenced by similar patterns as all bee individuals. However, only forest distance significantly reduced the number of solitary bee individuals (Table 1). We cannot draw clear conclusions on the social bees, because social bees visited the cucumber flowers 
only sporadically ( $6 \%$ of all individuals) with $A$. cerana clustered in one homegarden during our observations, and applying statistical models resulted in low power of the analysis with the NULL model being the best model.

\section{BEE BODY SIZE}

Small bees ( $\mathrm{n}=525$ observations) differed from large bees with respect to the management variables. The best model for small bees included the variables forest distance, \% flower cover, and \% homegarden area, but small bees increased significantly only with increasing proximity to the forest and increasing \% flower cover (Table 1). Large bees ( $\mathrm{n}=198$ observations) followed the same pattern as all bees and were influenced by the interaction of flower cover ${ }^{*}$ homegarden area (Table 1 ). However, forest distance was not important for large bees (Table 1).

Table 2: Predicted net income (in US\$ and \% relative to the mean income) of small-scale cucumber (Cucumis sativus L.) production in different settings of high (50\%) and low (15\%) adjacent homegarden area, distance of near $(5 \mathrm{~m})$ and far $(1500 \mathrm{~m})$ from to forest), and high $(50 \%)$ and low (15\%) homegarden flower cover.

\begin{tabular}{|c|c|c|c|c|}
\hline & \multicolumn{2}{|c|}{ near the forest $(50 \mathrm{~m})$} & \multicolumn{2}{|c|}{ far from the forest $(1.5 \mathrm{~km})$} \\
\hline & \multicolumn{4}{|c|}{$\%$ homegarden area } \\
\hline & low $(15 \%)$ & high $(50 \%)$ & low $(15 \%)$ & high (50\%) \\
\hline $\begin{array}{l}\text { flower cover low } \\
(15 \%)\end{array}$ & $62.00 \$ S E \pm 22.6 \$$ & $18.10 \$ \mathrm{SE} \pm 21.2 \$$ & $30.33 \$ \mathrm{SE} \pm 21.6 \$$ & $17.96 \$ S E \pm 21.2 \$$ \\
\hline $\begin{array}{l}\text { flower cover high } \\
(50 \%)\end{array}$ & $80.45 \$ S E \pm 23.5 \$$ & $180.02 \$ S E \pm 32.3 \$$ & $40.02 \$ S E \pm 21.9 \$$ & $98.81 \$ \mathrm{SE} \pm 24.5 \$$ \\
\hline
\end{tabular}

\section{DisCUSSION}

We show for the first time the importance of tropical bee management including the role of diverse homegardens across three spatial scales to provide adequate pollination services in small-scale vegetable production. This has important implications for smallholder farming practises to ensure pollination services for their crops. Cucumber production directly depends on bee pollination risking a nine-fold decline in income with pollinator loss. Bee management is complex and acts from the local habitat to the landscape scale. Flower resources in the homegarden attracted bees from natural habitat (rainforest) and adjacent, flower-rich homegardens. These habitats, thus, provided source population of pollinators spilling over across ecosystems, depending on the landscape setting 
as well as the species' response traits.

The most important variable determining the number of bee individuals was increasing the $\%$ flower cover (homegarden scale), but only if there were more than $20 \%$ homegardens in the adjacent landscape.

This situation also translated into increased net income for farmers via increased bee flower visitors and thus pollination services. Studies from temperate regions showed that wild bees were strongest influenced by natural or semi-natural habitat on similar spatial scales (Holzschuh et al. 2008; Smith et al. 2013). Flowers provide resources and can attract bees into the homegarden from the surrounding homegardens (e.g., Pereira-Peixoto et al. 2014). Our finding that floral resources determine wild bee individuals confirms patterns found in other studies (e.g., Veddeler et al. 2006; Carvalheiro et al. 2010). However, number of flowering plant individuals had no influence on cucumber flower visitors in Midwest US, but percentage semi-natural habitat (Smith et al. 2013). The amount and quality of the adjacent landscape matrix as habitat providing the source pool of species is often important but changes with region (Mandelik et al. 2012). Homegardens are highly heterogeneous habitats with a diversity of plant species providing not only flower but also nesting resources with trees and fallow areas (Kehlenbeck and Maas 2006) and may contribute to overall landscape heterogeneity. In our case, homegardens acted as important source habitats sustaining bee populations in adjacent homegardens, which were attracted by crop and non-crop flowers. Without homegardens the species pool and population size of bees in the surrounding area was small, providing few pollinators for crop pollination.

Increased availability of flowering plants can differentially influence the abundance of different bee functional groups (e.g., Klein et al. 2008; Jha and Vandermeer 2009). Solitary bees were the most important pollinators, whereas the honeybee A. cerana was rarely found on cucumber flowers. Wild solitary bees appeared to benefit from the homegardens through an increased flower cover providing food resources and a heterogeneous habitat with trees and open ground as nesting sites and refuges (e.g., Kim et al. 2006). This is in line with previous studies in tropical agricultural systems where the number of solitary bee individuals increased with higher flower cover (e.g., Klein et al. 2003a; Carvalheiro et al. 2010).

However, wild bee communities can also respond to larger spatial scales (e.g., Kremen et al. 2014), which highlights the importance of landscape-wide studies. In addition to flower resources, forest distance had the second most important impact on the number of bee individuals visiting the cucumber flowers. Cucumber production in a homegarden with high \% flower cover and located in a distance of less than $100 \mathrm{~m}$ from the forest border translated into the highest yields and net income 
for farmers. This is in line with findings that bees decrease with forest distance (reviewed in Ricketts et al. 2008; Garibaldi et al. 2011), whereas other did not find a connection to forest distance (e.g., Donaldson et al. 2002; Brosi et al. 2008). The relationship was logarithmic, meaning that the first $100 \mathrm{~m}$ from the forest were most important with half of the bees dropping out. This effect was driven by the smallest bees being most sensible to forest loss, due to their smaller foraging range and forest dependant life history (e.g., the stingless bees of the tribe Meliponini, Michener 2000; Roubik 2002). In contrast, large bees have wider foraging ranges and often nest in woody structures of houses (Michener 2000), and are, hence, influenced by local rather than landscape effects.

\section{CONCLUSION}

Closing yield gaps through the conservation of pollinators are key challenges for smallholder farmers in the tropics, as most of their crops need efficient pollination. Homegardens are often highly diverse man-made habitats, offering heterogeneous nesting and floral resources. Farmers can mitigate crop yield losses in homegardens coming from declines in pollination services by adapted bee management. In contrast to common believe, solitary, not social bees were the most important group for crop pollination. Given the interaction of farm and landscape scale variables relevant for bee management, there is no "one solution fits all" bee management. In homegardens with higher local flower cover and surrounded by other homegardens or close to natural forest, farmers can attract more bees to their crops and, thus, increase pollination services. In other words, farms must be managed according to the amount of natural or quality habitat available, because the on-garden amount of flowers is only efficient to attract high bee numbers if the adjacent landscape provides enough habitats acting as pollinator source.

Furthermore, bee guilds respond differently to anthropogenic change, so crop-specific pollinator requirements as well as bee trait-specific requirements must be understood to design efficient conservation plans. If small bees provide important services, crops should not be separated from pollinator source habitats such as forests. In conclusion, sustaining species-rich bee communities with multiple traits need multiple scale approaches. Our work highlights the complexity of the links between bee communities and agricultural practices at different spatial scales to sustain maximum crop yields. 


\section{ACKNOWLEDGEMENTS}

We would like to thank all our Indonesian field assistants, without them this would not have been possible. We thank Stephan Risch, Dra. Erniwati and Rosichon Ubaidillah for help with insect identification and species export; and Christoph Scherber for advice on statistical analysis. We thank RISTEK for issuing the research permit (No.0048/EXT/SIP/FRP/SM/X/2010). The project and IM was funded by the DAAD and the German Science Foundation (DFG, KL 1849/10-1 and TS 45/32-1). TWC was funded through a PostDoctoral Fellowship of the Leuphana University Lüneburg.

\section{REFERENCES}

Aizen, M.A., Garibaldi, L.A., Cunningham, S.A., Klein, A.M. 2008. Long-term global trends in crop yield and production reveal no current pollination shortage but increasing pollinator dependency. Current Biology 18:1572-1575.

Andersson, G.K., Birkhofer, K., Rundlöf, M., Smith, H.G. 2013. Landscape heterogeneity and farming practice alter the species composition and taxonomic breadth of pollinator communities. Basic and Applied Ecology 14:540-546.

Batáry, P., Báldi, A., Kleijn, D., Tscharntke, T. 2011. Landscape-moderated biodiversity effects of agri-environmental management: a meta-analysis. Proceedings of the Royal Society B 278:894-1902.

Benjamin, F.E., Reilly, J.R., Winfree, R. 2014. Pollinator body size mediates the scale at which land use drives crop pollination services. Journal of Applied Ecology 50:440-449.

Boreux, V., Kushalappa, C.G., Vaast, P., Ghazoul, J. 2013. Interactive effects among ecosystem services and management practices on crop production: Pollination in coffee agroforestry systems. Proceedings of the National Academy of Sciences of the United States of America 110:8387-8392.

Brittain, C., Bommarco, R., Vighi, M., Settele, J., Potts, S.G. 2010. Organic farming in isolated landscapes does not benefit flower-visiting insects and pollination. Biological Conservation 143:1860-1867.

Brosi, B.J., Daily, G.C., Shih, T.M., Oviedo, F., Durán, G. 2008. The effects of forest fragmentation on bee communities in tropical countryside. Journal of Applied Ecology 45:773-783.

Cane, J.H. 1987. Estimation of bee size using intertegular span (Apoidea). Journal of the Kansas Entomological Society 60:145-147. 
Carvalheiro, L.G., Seymour, C.L., Veldtman, R., Nicolson, S.W. 2010. Pollination services decline with distance from natural habitat even in biodiversity-rich areas. Journal of Applied Ecology 47:810-820.

Carvalheiro, L.G., Veldtman, R., Shenkute, A.G., Tesfay, G.B., Pirk, C.W.W., Donaldson, J.S., Nicolson, S.W. 2011. Natural and within-farmland biodiversity enhances crop productivity. Ecology Letters 14:251-259.

Concepcion, E.D., Díaz, M., Kleijn, D,, Baldi, A., Batary, P., Clough, Y., Gabriel, D., Herzog, F., Holzschuh, A., Knop, E. 2012. Interactive effects of landscape context constrain the effectiveness of local agri-environmental management. Journal of Applied Ecology 49:695705.

Cussans, J., Goulson, D., Sanderson, R., Goffe, L., Darvill, B., Osborne, J.L. 2010. Two beepollinated plant species show higher seed production when grown in gardens compared to arable farmland. PloS One 5, e11753.

Donaldson, J., Nänni, I., Zachariades, C., Kemper, J. 2002. Effects of habitat fragmentation on pollinator diversity and plant reproductive success in renosterveld shrublands of South Africa. Conservation Biology 16:1267-1276.

Free, J.B. 1993. Insect pollination of crops. London, UK: Academic Press.

Garibaldi, L.A., Steffan-Dewenter, I., Kremen, C., Morales, J.M., Bommarco, R., Cunningham, S.A., Carvalheiro, L.G., Chacoff, N.P., Dudenhoeffer, J.H., Greenleaf, S.S. 2011. Stability of pollination services decreases with isolation from natural areas despite honey bee visits. Ecology Letters 14:1062-1072.

Gelman, A. 2008. Scaling regression inputs by dividing by two standard deviations. Statistics in Medicine 27:2865-2873.

Gonzalez-Varo, J.P., Biesmeijer, J.C., Bommarco, R., Potts, S.G., Schweiger, O., Smith, H.G., Steffan-Dewenter, I., Szentgyorgyi, H., Woyciechowski, M., Vila, M. 2013. Combined effects of global change pressures on animal-mediated pollination. Trends in Ecology \& Evolution 28:524-530.

Goulson, D. 2003. Bumblebees: their behaviour and ecology. Oxford, UK: Oxford University Press.

Greenleaf, S.S., Kremen, C. 2006. Wild bee species increase tomato production and respond differently to surrounding land use in Northern California. Biological Conservation 133:8187.

Greenleaf, S.S., Williams, N.M., Winfree, R., Kremen, C. 2007. Bee foraging ranges and their 
relationship to body size. Oecologia 153:589-596.

Hoehn, P., Tscharntke, T., Tylianakis, J.M., Steffan-Dewenter, I. 2008. Functional group diversity of bee pollinators increases crop yield. Proceedings of the Royal Society B 275:2283-2291.

Holzschuh, A., Steffan-Dewenter, I., Kleijn, D., Tscharntke, T. 2007. Diversity of flower-visiting bees in cereal fields: effects of farming system, landscape composition and regional context. Journal of Applied Ecology 44:41-49.

Holzschuh, A., Steffan-Dewenter, I., Tscharntke, T.. 2008. Agricultural landscapes with organic crops support higher pollinator diversity. Oikos 117:354-361.

Jha S., Vandermeer J.H. 2009 Contrasting bee foraging in response to resource scale and local habitat management. Oikos 118:1174-1180.

Kehlenbeck, K., Maass, B. 2006. Are tropical homegardens sustainable? Some evidence from Central Sulawesi, Indonesia. In Tropical Homegardens (ed. B.M. Kunar, P.K.R. Nair), pp. 339-354. Dordrecht, The Netherlands: Springer.

Kehlenbeck, K. 2007. Rural homegardens in Central Sulawesi, Indonesia: an example for a sustainable agro-ecosystem. Göttingen, Germany: University of Goettingen [Doctoral Dissertation].

Kennedy, C.M., Lonsdorf, E., Neel, M.C., Williams, N.M., Ricketts, T.H., Winfree, R., Bommarco, R., Brittain, C., Burley, A.L., Cariveau, D. 2013. A global quantitative synthesis of local and landscape effects on wild bee pollinators in agroecosystems. Ecology Letters 16:584-599.

Kim, J., Williams, N., Kremen, C. 2006. Effects of cultivation and proximity to natural habitat on ground-nesting native bees in California sunflower fields. Journal of the Kansas Entomological Society 79:309-320.

Klein, A.M., Steffan-Dewenter, I., Tscharntke, T. 2003a. Fruit set of highland coffee increases with the diversity of pollinating bees. Proceedings of the Royal Society B 270:955-961.

Klein, A.M., Steffan-Dewenter, I., Tscharntke, T. 2003b. Pollination of Coffea canephora in relation to local and regional agroforestry management. Journal of Applied Ecology 40:837-845.

Klein, A.M., Vaissiere, B.E., Cane, J.H., Steffan-Dewenter, I., Cunningham, S.A., Kremen, C., Tscharntke, T. 2007. Importance of pollinators in changing landscapes for world crops. Proceedings of the Royal Society B 274:303-313.

Klein, A.-M., Cunningham, S.A., Bos, M., Steffan-Dewenter, I. 2008. Advances in pollination ecology from tropical plantation crops. Ecology 89:935-943.

Kremen, C., Williams, N.M., Thorp, R.W. 2002. Crop pollination from native bees at risk from agricultural intensification. Proceedings of the National Academy of Sciences of the United 
States of America 99:16812-16816.

Kremen, C., Williams, N.M., Bugg, R.L., Fay, J.P., Thorp, R.W. 2004. The area requirements of an ecosystem service: crop pollination by native bee communities in California. Ecology Letters 7:1109-1119.

Kremen, C., Williams, N.M., Aizen, M.A., Gemmill-Herren, B., LeBuhn, G., Minckley, R., Packer, L., Potts, S.G., Steffan-Dewenter, I., Vazquez, D.P. 2007. Pollination and other ecosystem services produced by mobile organisms: A conceptual framework for the effects of land-use change. Ecology Letters 10:299-314.

Krishnan, S., Kushalappa, C.G., Shaanker, R.U., Ghazoul, J. 2012. Status of pollinators and their efficiency in coffee fruit set in a fragmented landscape mosaic in South India. Basic and Applied Ecology 13:277-285.

Maertens, M., Zeller, M., Birner, R. 2002. Explaining agricultural land use in villages surrounding the Lore Lindu National Park in Central Sulawesi, Indonesia. Bogor, Indonesia: STORMA Discussion Paper Series.

Mandelik, Y., Winfree, R., Neeson, T., Kremen, C. 2012. Complementary habitat use by wild bees in agro-natural landscapes. Ecological Applications 22:1535-1546.

McGregor, S.E. 1976 Insect pollination of cultivated crop-plants. U.S.D.A. Agriculture Handbook No. 496, 93-98. Version with some updated information for some crop species available at http://gears.tucson.ars.ag.gov/book/.

Michener, C.D. 2000. The bees of the world. Baltimore, US: JHU Press.

Motzke, I., Tscharntke, T., Wanger, T.C., Klein, A.M. 2014. Pollination mitigates cucumber yield gaps more than pesticide and fertilizer use in tropical smallholder gardens. Journal of Applied Ecology (doi: 10.1111/1365-2664.12357)

Natawidjaja, R., Reardon, T., Shetty, S., TI, P. 2007. Horticultural producers and supermarket development in Indonesia. Indonesia: UNPAD/MSU/World Bank, World Bank report no. 38543.

Pereira-Peixoto, M.H., Pufal, G., Martins, C.F., Klein, A.M. 2014. Spillover of trap-nesting bees and wasps in an urban-rural interface. Journal of Insect Conservation 18:815-826.

Pinheiro, J., Bates, D., DebRoy, S., Sarkar, D., The R Core Development Team. 2009. nlme: linear and nonlinear mixed effects models. R package v. 3.1-93. See http://cran.r-project.org/web/ packages/nlme/index.html.

Potts, S.G., Biesmeijer, J.C., Kremen, C., Neumann, P., Schweiger, O., Kunin, W.E. 2010. Global pollinator declines: trends, impacts and drivers. Trends in Ecology \& Evolution 25:345- 
353.

R Development Core Team. 2013 R: a language and environment for statistical computing. Vienna, Austria: R Foundation for Statistical Computing.

Ricketts, T.H. 2004. Tropical forest fragments enhance pollinator activity in nearby coffee crops. Conservation Biology 18:1262-1271.

Ricketts, T.H., Regetz, J., Steffan-Dewenter, I., Cunningham, S.A., Kremen, C., Bogdanski, A., Gemmill-Herren, B., Greenleaf, S.S., Klein, A.M., Mayfield, M.M. 2008. Landscape effects on crop pollination services: are there general patterns? Ecology Letters 11:499-515.

Roubik, D.W. 2002. Tropical agriculture: the value of bees to the coffee harvest. Nature 417:708708.

Rundlöf, M., Nilsson, H., Smith, H.G. 2008. Interacting effects of farming practice and landscape context on bumble bees. Biological Conservation 141:417-426.

Samnegård, U., Persson, A.S., Smith, H.G. 2011. Gardens benefit bees and enhance pollination in intensively managed farmland. Biological Conservation 144, 2602-2606.

Schüepp, C., Herzog, F., Entling, M.H. 2014. Disentangling multiple drivers of pollination in a landscape-scale experiment. Proceedings of the Royal Society B 281:20132667.

Smith, A., Bentley, M., Reynolds, H. 2013. Wild bees visiting cucumber on Midwestern US Organic Farms Benefit from Near-Farm Semi-Natural Areas. Journal of Economic Entomology106:97-106.

Smith, R., Thompson, K., Hodgson, J., Warren, P., Gaston, K. 2006. Urban domestic gardens (IX): composition and richness of the vascular plant flora, and implications for native biodiversity. Biological Conservation 129:312-322.

Tscharntke, T., Klein, A.M., Kruess, A., Steffan-Dewenter, I., Thies, C. 2005 Landscape perspectives on agricultural intensification and biodiversity-ecosystem service management. Ecology Letters 8:857-874.

Tscharntke, T., Clough, Y., Wanger, T.C., Jackson, L., Motzke, I., Perfecto, I., Vandermeer, J., Whitbread, A. 2012. Global food security, biodiversity conservation and the future of agricultural intensification. Biological Conservation 151:53-59.

Veddeler, D., Klein, A.M., Tscharntke, T. 2006. Contrasting responses of bee communities to coffee flowering at different spatial scales. Oikos 112:594-601.

Wcislo, W.T., Wille, A., Orozco, E. 1993. Nesting biology of tropical solitary and social sweat bees, Lasioglossum (Dialictus) figueresi Wcislo and L.(D.) aeneiventre (Friese) (Hymenoptera: Halictidae). Insectes Sociaux 40:21-40. 
Williams, N.M., Kremen, C. 2007. Resource distributions among habitats determine solitary bee offspring production in a mosaic landscape. Ecological Applications 17:910-921.

Zuur, A.F., Ieno, E.N., Elphick, C.S. 2010. A protocol for data exploration to avoid common statistical problems. Methods in Ecology and Evolution 1:3-14.

\section{SUPPORTING INFORMATION}

\section{SUPPLEMENTARY TABLE $\mathbf{S 1}$}

Online Supplementary Material Table S1 Correlation matrix of the plant, habitat and landscape explanatory variables: Significant correlations at $P<0.05$ are shown in bold.

\section{$\%$ flower cover $\quad \%$ homegarden area}

\begin{tabular}{c|cc} 
\% homegarden area & -0.2 & \\
Forest distance & 0.08 & 0.75
\end{tabular}

\section{Supplementary Figure S1}

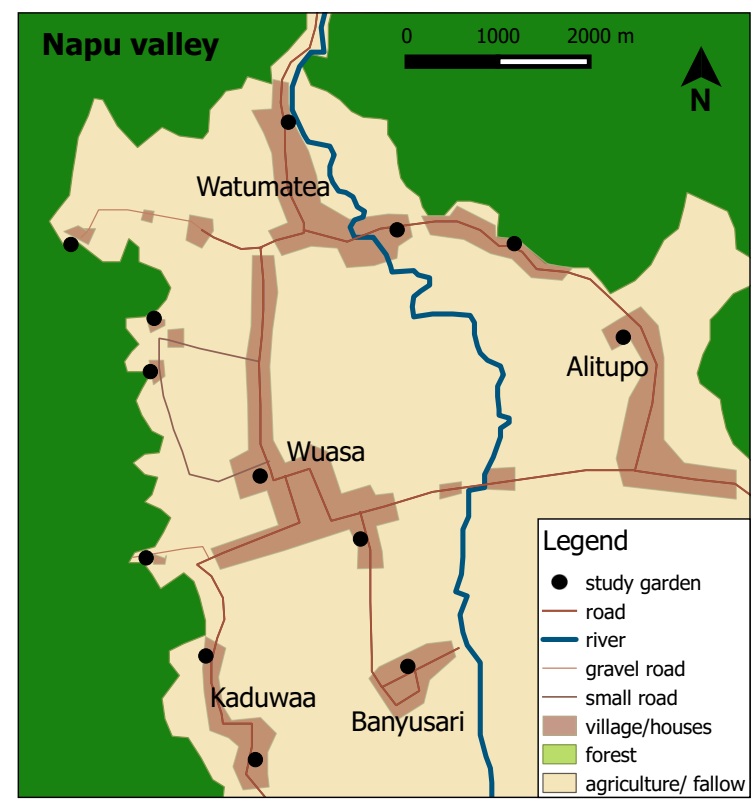

Fig. S1: Map of the study area and distribution of study gardens in the Napu valley 


\section{SUPPLEMENTARY TABLE $\mathbf{S} 2$}

Online Supplementary Material Table S2: Bee species and number of individuals visiting cucumber flowers with their respective body size and sociality.

\begin{tabular}{lccc} 
Bee species & individuals & body size & sociality \\
\hline Nomia fulvata (Fabricius) & 268 & medium & solitary \\
Amegilla sp.1 & 111 & large & solitary \\
Xylocopa aestuans (Linnaeus) & 69 & large & solitary \\
Ceratina cognata Smith & 63 & small & solitary \\
Lasioglossum vagans (Smith) & 49 & small & unknown \\
Ceratina rugifrons Smith & 45 & small & solitary \\
Apis cerana Fabricius & 36 & small & social \\
Lasioglossum halictoides (Smith) & 32 & small & unknown \\
Ceratina sp.1 & 15 & small & solitary \\
Gnathonomia thoracica Smith & 14 & small & solitary \\
Xylocopa dejeanii Lepeletier & 12 & large & solitary \\
Nomia formosa Smith & 8 & small & solitary \\
Geniotrigona incisa (Sakagami and Inoue) & 5 & small & social \\
Patellapis celebensis (Blüthgen) & 5 & small & unknown \\
Homalictus vechti Pauly & 4 & small & unknown \\
Amegilla sp.2 & 3 & large & solitary \\
Apis dorsata binghami Cockerell & 3 & large & social \\
Thyreus nitidulus (Fabricius) & 3 & small & solitary \\
Lipotriches philippinensis (Cockerell) & 2 & small & solitary \\
Ceratina unimaculata Smith & 2 & small & solitary \\
Tetragonula sp. & 2 & small & social \\
Megachile aterrima Smith & 1 & small & solitary \\
Ceyalictus sp. & 1 & small & unknown \\
\hline & & & \\
& & &
\end{tabular}




\section{SuPPlementary Figure S2}

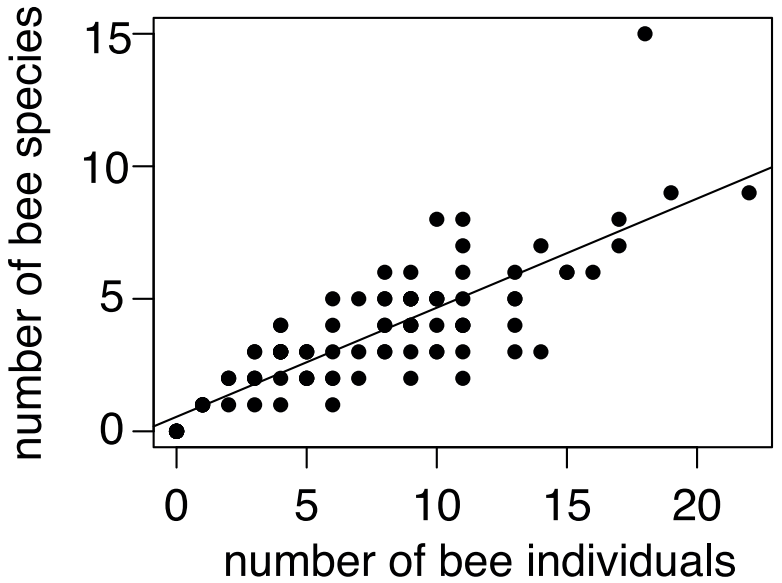

Fig.S2: Correlation of number of bee individuals and number of bee species (Pearson's correlation, $\mathrm{t}=15.24$, d.f. $=101, P<0.0001, \mathrm{r}=0.83$ ) 


\section{Chapter 4}

\section{ANT SEED PREDATION, PESTICIDE APPLICATIONS AND FARMERS' INCOME FROM TROPICAL MULTI-CROPPING GARDENS}

Authors: Iris Motzke, Teja Tscharntke, Navjot S. Sodhi, Alexandra-Maria Klein and Thomas C. Wanger 


\section{Abstract}

Tropical small-holder farmers rely on sustainable food production. Crop seed predation by ants can cause substantial yield loss and result in high pesticide use. We conducted field experiments and questionnaire-based surveys aiming to assess the effect of sown-seed predation on four crop species (Cucumis sativus, Daucus carota, Capsicum frutescens and Solanum melongena) in 15 vegetable gardens and the resulting impact on the net income of Indonesian farmers. Furthermore, we tested a commonly applied insecticide and herbicide for seed, seedling and plant protection aiming to understand their effect on ant seed predation. We found that the mean percentage of seeds removed per garden was $42.0 \%, 49.4 \%, 48.0 \%$ and $50.6 \%$ for C. sativus, D. carota, C. frutescens and S. melongena, respectively, halving the farmers' income after considering initial and operational costs. Insecticide and herbicide treatments did not affect seed predation success or overall ant abundance, although they had positive and negative effects on ant species-specific abundance. High overall ant abundance caused high seed predation rate in all gardens as a result of a functional redundancy of ant species, which compensated for pesticide-related species loss. Environmentally-friendly and more sustainable practices such as overseeding or seedling production in nurseries could substitute for these inefficient approaches of chemical pest control, although this requires further research.

Keywords: Agroecosystem, functional redundancy, herbicide, Indonesia, insecticide, invasive ants, local economies, Sulawesi, vegetable gardens 


\section{INTRODUCTION}

Rapid human population growth is paralleled by an increasing demand for nutritious food (Hobbs, 2007; Dias, 2010) with a major focus on poor tropical countries (Bawa et al. 2004; Foleyet al. 2005, 2011). For food and income security, crop seeds are highly valuable assets to farmers because seed quality and survival are directly related to crop yield (e.g. the global vegetable seed market was US\$3.5 billion in 2008; Monsanto, 2010). The loss of newly-sown seeds to seed predators poses high costs and can greatly decrease income as a result of crop losses.

In the tropics, ants are among the most important seed predators (Hulme \& Kollmann, 2004; Albert et al. 2005; ander Wall et al. 2005). Although tropical smallholders play an important role for food production (Perfecto \& Vandermeer, 2010), our knowledge on seed predation comes either from ild plant species, from predation on crops at harvest or weed seeds. The few studies assessing sown-seed predation mainly focus on crop species in temperate regions. For example, a study from the U.S.A. shows that the fire ant Solenopsis invicta (Buren) causes up to 20-30\% soybean yield loss as a result of the destruction of seeds (Adams et al. 1983). In Australia, ants can cause up to 40-90\% seed losses on sown pastures (Johns \& Greenup, 1976; Kelman et al. 2002). Yield losses of newly-sown crop seeds caused by harvester ants in semi-arid cereal fields of Spain were insignificant (0.2\% of yield losses; Baraibar et al. 2011). In the laboratory,

damaged or removed up to $95 \%$ of seeds of various crop species (e.g. soybean, corn, sorghum and wheat; Drees et al. 1991; Ready \& Vinson, 1995; Morrison et al. 1997). We are aware of only one non-manipulative study in the tropics on dryland rice in the Philippines, where seed loss from various insects, including ants (e.g. Solenopsis geminata Fabricius), was up to 71\% (Litsinger et al. 2009). The effect of seed predation by ants can therefore be substantial.

To protect crop seeds against soil-born herbivores and ants, insecticides such as imidacloprid (neonicotinoid) and carbofuran (carbamate) have long been commercially applied (Munkvold, 2009; de Almeida et al. 2010). Herbicides are also frequently applied before sowing to control early weed pressure, although they could also affect arthropods by altering food resources, microclimates and shelter (Chiverton \& Sotherton, 1991; Edwards, 1991; Ewald \& Aebischer, 2000; Yardim \& Edwards, 2002; Pereira et al. 2005). Although negative effects of pesticides (insecticides and herbicides) on the environment including biotic interactions and human health have been demonstrated (Kesavachandran et al. 2009; Brittain et al. 2010; Daam \& Van den Brink, 2010), the effect on tropical biotic interactions has received little attention.

Based on an experimental approach, questionnaire-based surveys and Bayesian regression 
modelling, we investigated for the first time the effects of pesticides on vegetable seed predation and farmers' income in Sulawesi, Indonesia. We first tested insecticide and herbicide application on seed predation by ants on four crops in Indonesian small-scale gardens. In addition, we assessed the ant communities in our gardens with a focus on dominant seed-eating species. We also tested the effect of natural forests (i.e. as refugium habitat for many ant species) on ant species richness and abundance and seed predation. We then calculated the importance of seed predation for net income of local farmers including initial and operational costs. In the present study, we tested the hypotheses: (i) sown-seed predation by ants highly affects our focal crop species; (ii) the use of herbicides and insecticides can remedy ant seed predation; and (iii) ant seed predation has a measurable negative impact on the income of local farmers.

\section{Materials AND METHOdS}

\section{STUDY AREA}

The study was conducted in the Napu Valley, Central Sulawesi (Indonesia) at the eastern margin of the Lore Lindu National Park (1100-1200ma.s.l.; see Supporting information, Fig. S1). The region has no pronounced seasonality with a mean $\pm S D$ annual temperature of $24.0 \pm 0.16{ }^{\circ} \mathrm{C}$ and a mean \pm SD monthly rainfall of $143.7 \pm 22.7 \mathrm{~mm}$, providing optimal conditions for farming yearround. Most inhabitants are farmers of paddy rice, cacao and vegetables (Van Rheenen et al. 2004). The landscape is a mosaic of natural forest and small-scale agriculture with intensive pesticide applications (Wanger et al. 2010). Multicropping is common for small-scale farming of our study area.

\section{Plot Setting AND TReatments}

We selected 15 multi-copping vegetable gardens with a distance $>1 \mathrm{~km}$ between the gardens (to ensure statistical independence) and an isolation gradient from natural forest $(0-2500 \mathrm{~m})$ to investigate the effects of natural forest on seed predators and predation rates. In each garden, we planted four crop species (cucumber Cucumis sativus L., carrot Daucus carota L., chili pepper Capsicum frutescens L. and eggplant Solanum melongena L.) over 6 months, starting in July 2010. Plants were sown by placing the seeds on the newly-prepared bed rows (height $40 \mathrm{~cm}$, width $1 \mathrm{~m}$, length $10 \mathrm{~m}$ ) at distances of 50, 70 and $80 \mathrm{~cm}$ between each plant for cucumber, eggplant and chili, respectively. Carrots were sown by scattering the seeds by hand evenly over the beds. We divided each garden (size $300 \mathrm{~m} 2$ ) into four equally sized plots and applied four pesticide treatments: insecticide $(\alpha$-cypermethrin 
$30 \mathrm{~g} / \mathrm{L}$ and permethrin $20.04 \mathrm{~g} / \mathrm{L}$ ) spraying; herbicide (paraquat-dichlorid $297 \mathrm{~g} / \mathrm{L}$ ) spraying; the combination of insecticide and herbicide (combi) spraying; and no pesticide application (control). Starting in July 2010, we applied the pesticide treatments weekly in accordance with common local management practices. We chose these products because they are the most commonly used in vegetable gardens of the study region to protect seeds, seedlings and the grown plants. The active ingredients of both pesticides were classified as moderately hazardous (class II) by the World Health Organization (WHO) (2009). We established 2-m drainage buffers between plots in each garden to avoid pesticide drifts between treatments.

\section{SEED PREDATION EXPERIMENT}

We only referred to seed predation if a seed was: (i) removed from the experiment or (ii) heavily damaged such that germination in our experimental gardens was unlikely. Our seed sources (commercial C. sativus, S. melongenaand C. frutescens seeds and locally produced D. carota seeds), plot preparation and sowing methods were the same as those used in local farm management practices. Because most commercial seeds have an insecticide coating, we tested the effect of the coating on seed predation rate in a pilot study. After baiting each of five seed chambers (see below) in one garden with five seeds per crop species, we found no differences between the mean \pm SE number of seeds removed or damaged by ants of coated $(2.8 \pm 1.3)$ versus uncoated $(3.2 \pm 1.3)$ seeds. For a realistic set-up, we used coated seeds in our experiments. Twelve hours prior to the experiment, S. melongenaand $C$. frutescens seeds were placed in water to enhance germination (this is common practice by the local farmers). We used small plastic containers (hereafter 'seed chambers') to observe ant seed predation. Before placing five seeds of each crop species directly onto the soil surface (common practice), a fine mesh $(1 \mathrm{~mm})$ had been placed $2 \mathrm{~cm}$ under the soil (to avoid seed removal by soil organisms). We then placed a plastic container (diameter $4 \mathrm{~cm}$ ) with its bottom removed on top of the seeds. Four holes (width $0.5 \mathrm{~cm}$ ) (one on each side of the seed chamber) were cut in for ant access and to exclude other seed predators (e.g. rats or mice) and minimize disturbance by rain and wind. We monitored the seed chambers for a 3-h period on 3 days prior to the experiment to assess whether only ants enter the seed chambers.

In total, we monitored seed predation for $C$. sativus, S. melongena, D. carota and C. frutescens with two replicates for each of the four treatments (10 seeds per crop and per garden). We checked the number of seeds removed or damaged in each seed chamber daily over a 1-week period in October 2010. Any reduction in seed number was attributed to seed-predating ants (Fig. 1) because we did not observe other animals entering the seed chambers during the pilot study and the experiment. 


\section{ANT SPECIES RICHNESS AND ABUNDANCE}

To assess ant diversity and abundance for all treatments, we used standard-size plates with tuna baits and $70 \%$ sugar solution. Tuna baits are frequently used to assess ant communities (V'ele et al. 2009; Wielgoss et al. 2010) because tuna contains lipids that are attractive to omnivorous ants (Marshall et al. 1979; Skidmore \& Heithaus, 1988). After 15, 30, 45 and 60min, we recorded the abundance of all ant species occurring at the baits on two plates in each plot (a total of eight plates per garden; Wielgoss et al. 2010; Wanger et al. 2011). We repeated the sampling twice in October and December 2010 before and after the seed predation experiment.

\section{COSTS OF SEED PREDATION}

We estimated net income generated from all crops with data from two standardized questionnaires and experimental data on crop yield, seed and crop prices, and operational expenses for a $300-\mathrm{m} 2$ garden (common size of a vegetable garden in Sulawesi; see Supporting information S1 and S2 and Table S1).

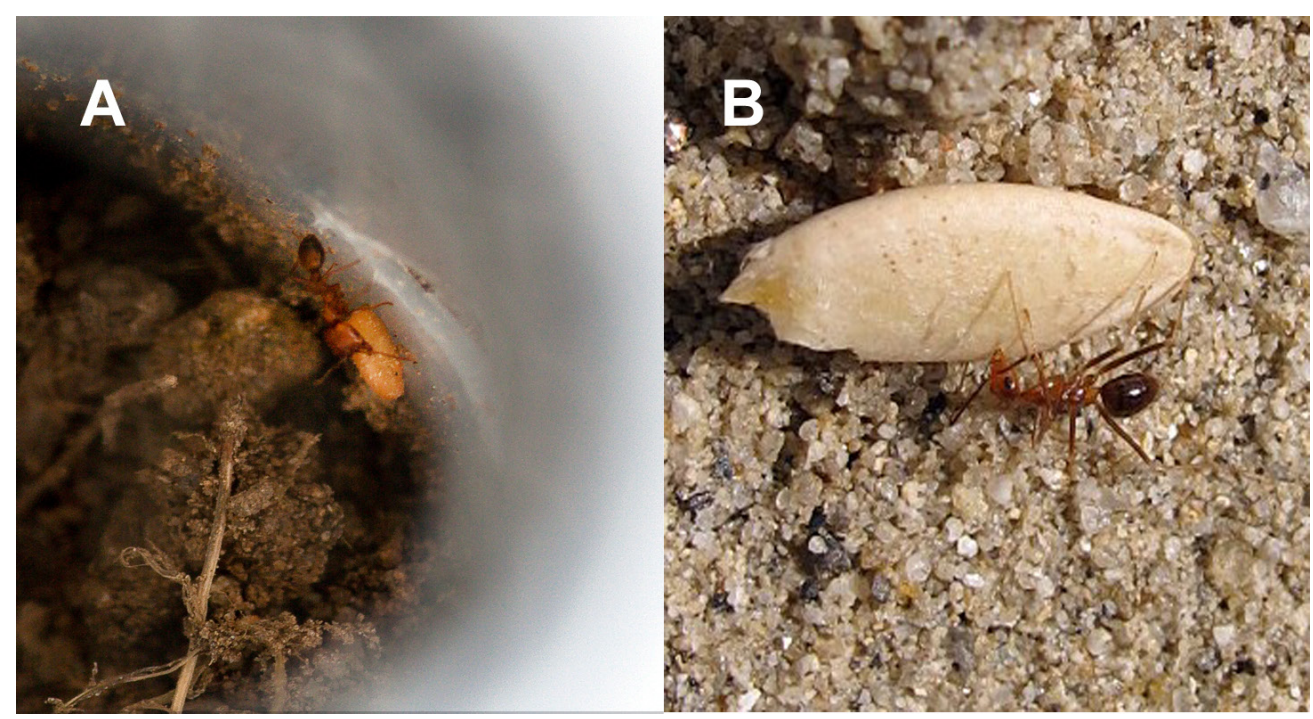

Figure 1 (a) Solenopsis geminata removing an Solanum melongena seed from the experimental seed chamber; (b) Anoplolepis gracilipes feeding on a Cucumis sativus seed.

We derived the replicated measure of seed predation from all 15 study gardens. Income generated from one plant individual was calculated as the mean yield per plant species multiplied by the price per kg. We used the price at the time of the experiment as the set price, although we also included the 1 - year price variations of 2010 . We calculated the net income by subtracting operational costs for fertilizer, pesticides and labour costs (i.e. the time spent working and not being 
able to work elsewhere) from the income generated from one single plant individual for all target crop species. As total net income, we started with the initial expenses (land preparation, seed cost and pesticides) and then added the value for each surviving plant individual in $300 \mathrm{~m} 2$. We assumed $0 \%$ and $100 \%$ seed predation corresponding to a respective plant survival of $100 \%$ and $0 \%$. This is a conservative assumption because data to include germination success or yield loss from other factors such as unexpected pest outbreaks or changing climatic conditions are not available.

\section{STATISTICAL ANALYSIS}

We used Bayesian regression modelling to measure the strength of treatments on seed predation with the numbers of seeds removed or damaged (after 1week per crop and plot) being the response variable. For the initial model structure (full model), we included garden (site) as a random effect to account for plot-dependent differences. Treatment (treat) as a fixed effect was nested within garden to account for plots in individual gardens and distance (dist) to forest as the second fixed effect. After initial multi-model inference (Anderson, 2007) for the best fixed and random effects modelling structure, we excluded dist as fixed effect from the final model. We also used Bayesian regression modelling to assess the effect of forest isolation on seed predation and ant species richness and abundance (dist ; classified in three categories; 0-100; >100-1000; >1000-2500m with five replicates each). We used Bayesian regression modelling to measure the individual and additive effects of treatments on ant abundance of the three most abundant species: the invasive yellow crazy ant Anoplolepis gracilipes Smith, Tapinoma spp., the invasive fire ant S. geminata, and ant species richness (spr) of seedpredating ants. After multi-model inference, the final model structure was the same as above with site as random effect and the fixed effect treat (nested within site). The fixed effect dist was excluded from the final model. To test whether we found the same proportion of seedpredating ants across our treatment plots, we calculated the proportion of species and individuals known to prey on seeds in each plot as the number of seed-predating species or individuals divided by the total number of species per plot. With a Kruskal-Wallis test, we tested differences in the percentage of seed eating-ant species and abundance (dependent variables) for the four treatments (response variable).

We performed all analyses in r, version 2.12.1 (R Development Core Team, 2010) with the package r2winbugs (Sturtz et al. 2005) and winbugs, version 1.4.3 (Lynn et al. 2000) for Bayesian analysis. 


\section{ReSUlTS}

\section{EFFECT OF PESTICIDES OR DISTANCE TO FOREST ON SEED PREDATION}

We did not find an effect of the pesticide treatments on seed predation in any of the four crops tested [the credibility intervals (error bars) for any estimated parameter mean of the pesticide treatments did overlap the zero reference line] (Fig. 2). Distance to forest and, hence, garden location in the landscape, also had no effect on seed predation (credibility intervals overlap the zero reference line; see Supporting information, Fig. S2).

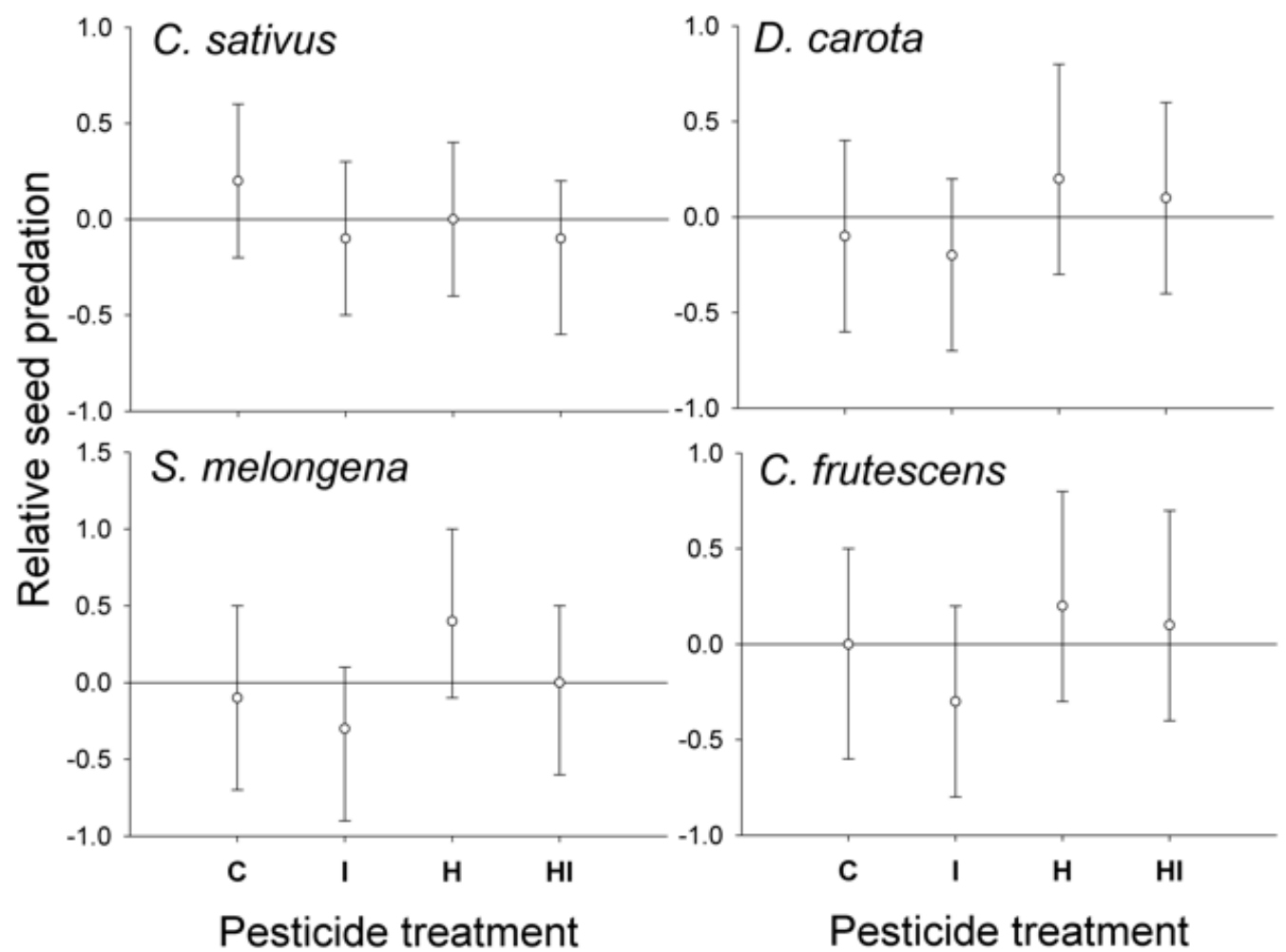

Figure 2 Pesticide treatment effects on seed predation of the four target crop species. The credibility intervals of the treatment overlap with zero, which means that the pesticide treatment had no effect on seed predation. C, control; I, insecticides; H, herbicides; HI, insecticide and herbicide combi treatment

\section{Pesticide EFfeCts on ANT SPECIES RICHNESS AND ABUNDANCE}

We found a total of 18 different ant species of which over $60 \%$ are known to prey on seeds (see Supporting information, Table S2). Although none of the species is strictly granivorous, S. geminata was described as omnivorous and granivorous. The most abundant ant species that removed or preyed on seeds, were the invasive fire ant $S$. geminata, invasive yellow crazy ant A. gracilipes and Tapinoma 
$s p$ (present on 10, eight and 13 gardens with mean \pm SE abundances/recruitment of $116.3 \pm 11.8$, $81.9 \pm 12.3$ and $63.5 \pm 7.1$, respectively). The abundance of these species differed across the gardens and plots; for example, S. geminata and A. gracilipes occurred only on three gardens at the same time and only in one garden at the same treatment plot and time (see Supporting information, Table S3), although they were the dominant species in the overall samples. However, total species and individual abundances of all ant species known to consume seeds were equally distributed across the plots and at least one of the abundant species was present in all gardens (percentage species: Kruskal-Wallis $\chi^{2}=7.993$, d.f. $=5, \mathrm{P}=0.157$; percentage abundances: Kruskal-Wallis $\chi^{2}=35.234$,

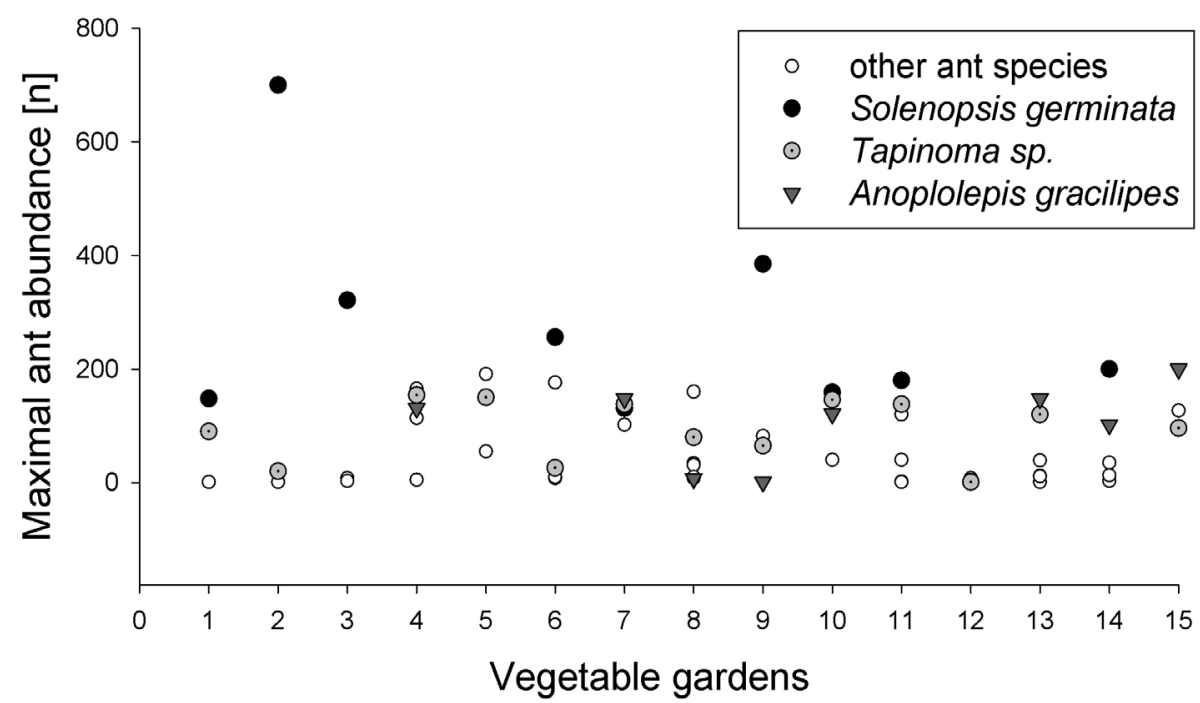

Figure 3 Abundances of different ant species found on the bait plates across all gardens.

d.f. $=29, \mathrm{P}=0.197$; Fig. 3).

The three most common species responded differently to the pesticide treatments. We found an effect if the credibility intervals in Fig. 4 did not overlap with zero. Only the combi treatment had a negative (decreasing) effect on $A$. gracilipes abundance (Fig. 4). For Tapinoma sp., abundances were high for the control and the herbicide treatment and decreased in the insecticide and combi treatment (Fig. 4). By contrast, no effect of treatments could be found for S. geminata or for total species richness (Fig. 4). Distance to forest had no effect on the three most abundant ant species or on species richness because all credibility intervals do overlap with zero (see Supporting information, Fig. S2). 


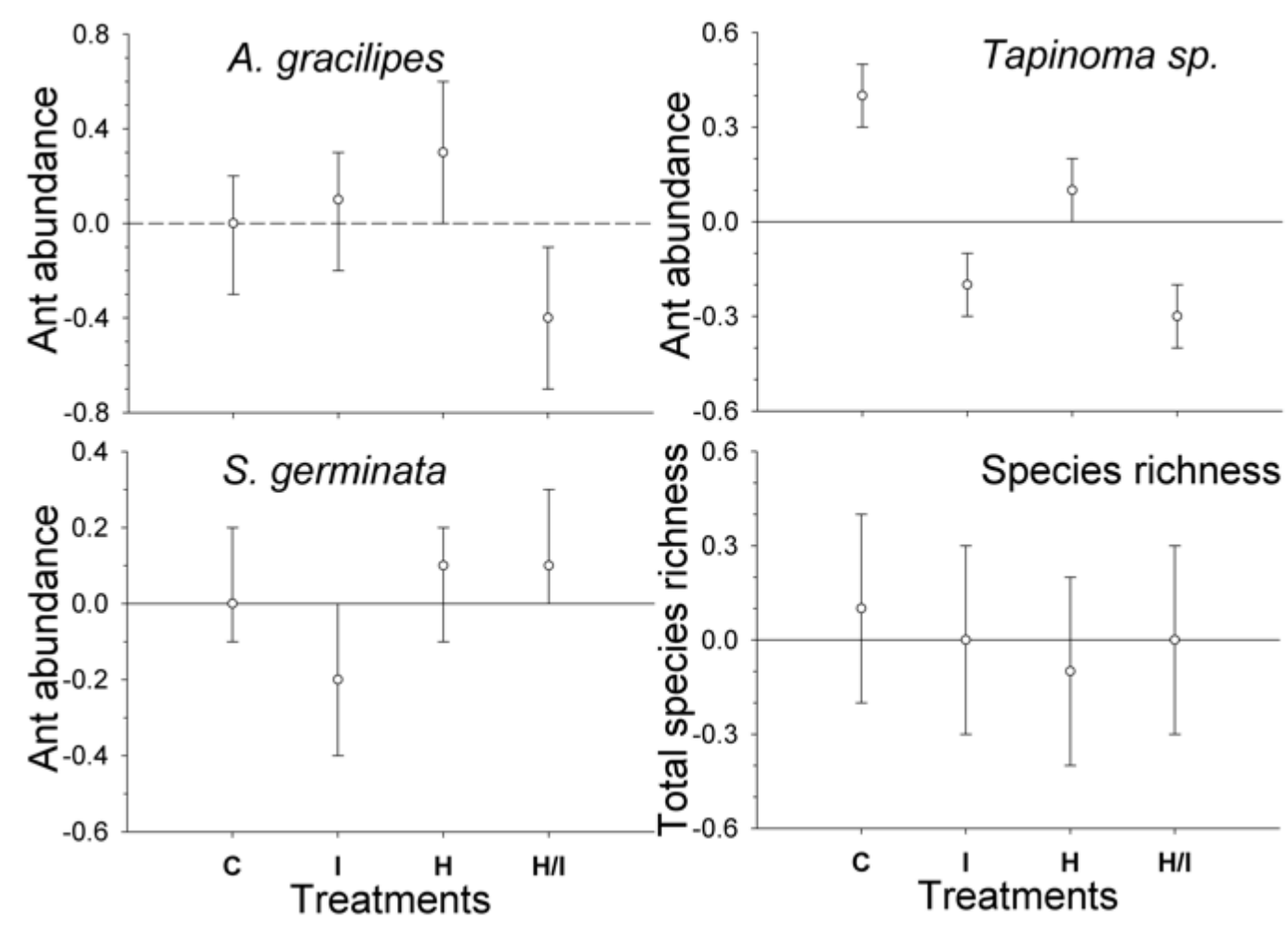

Figure 4 Pesticide treatment effects on the different ant species. C, control; I, insecticides; H, herbicides; HI, insecticide and herbicide combi treatment..

\section{IMPACT OF SEED PREDATION ON NET INCOME}

The mean \pm SE percentage of seeds removed or damaged by ants across treatments for all gardens was $42.0 \pm 0.37 \%, 49.4 \pm 0.26 \%, 48.0 \pm 0.31 \%$ and $50.6 \pm 0.32 \%$ for $C$. sativus, $S$. melongena, $C$. frutescens and $D$. carota, respectively. In conjunction with our questionnaire-based survey in the study area, we found that crop investment of farmers is only worthwhile if the net income is more than a 'twice the invested expenses' threshold to cover expenses for the current and assure funds for the next season. The results of our seed predation experiment suggest that seed predation reduces net income below the threshold for $D$. carota and $S$. melongenaand leaves it only slightly above it for C. frutescens and C. sativus (Fig. 5). Except for S. melongena, prices varied strongly. Hence, a combination of low prices and seed loss caused by ants will gain monetary losses for all four studied crop species in our study area. 

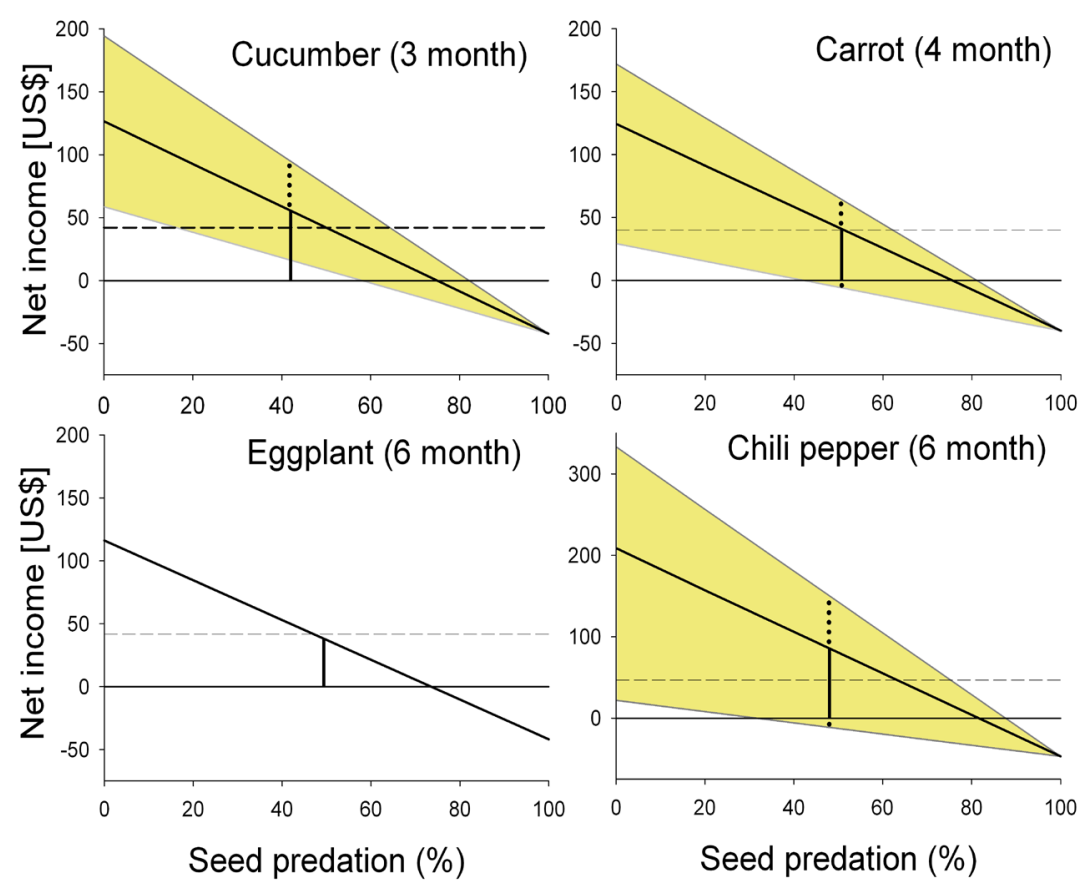

Figure 5 Ant seed predation impact on farmers' net income (gross income minus production expenses). At zero seed predation, the farmer's income equals income minus initial expenses and operational costs. The regression line shows the real net income at the time of the experiment. The highlighted area shows the range in prices that farmers received for their yield in 2010 (note that there was no price variation for Solanum melongena). The dashed horizontal line represents the threshold at which twice the farmer's expenses are compensated for the current and the next growing season (i.e. paying for field preparation and new seeds). Vertical lines indicate the seed predation rate identified in this study. Growing time given in month (from sowing until harvest) is given in parentheses after the crop species name.

\section{Discussion}

Agricultural production, especially that of annual and biannual crop species, depends on crop seed survival because seed loss directly translates into yield loss of an entire plant. Our experimental study is the first to quantify the effects of seed predation by ants of multiple crop species in a tropical agroecosystem.

In a review on harvester ants in natural systems, total annual seed removal was found to be between 10\% and 100\% depending on the plant species (MacMahon et al. 2000). Our results showing seed predation ranges of between $42 \%$ and $51 \%$ are lower compared with one other non-manipulative study on rice loss (Litsinger et al. 2009) and higher compared with studies from temperate regions (soybean production in the U.S.A.; Adams et al. 1983; cereal fields in Spain; Baraibar et al. 2011). At present, it is important to note that a comparison between studies and 
across climate zones is difficult because experimental studies from the tropics and studies with a focus on sown-seed predation by ants are extremely limited.

\section{Pesticide Management: A STRATEgY TO CONTROL SEED PREDATION?}

Pesticides are increasingly and routinely applied by local farmers to overcome yield loss as a result of pest and weed pressure. Our experiments to test the impact of pesticide management strategies to control ant seed predation showed no effect. However, we found that the same pesticide treatment showed contrasting effects for different ant species and either reduced or increased abundances of some ant species, whereas overall seed-predating ant species richness, abundance and seed-predation rates remained the same.

For the small ant species Tapinoma sp., the insecticide treatment appears to be effective. However, for the two invasive species $S$. geminata and $A$. gracilipes, we found no clear effect. $S$. geminata showed no significant effect for any treatment. The decrease in the combi treatment of A. gracilipes but no reaction to the herbicide or insecticide treatment might also be a result of interactions between the ant species. The presence and absence of $S$. geminata might influence $A$. gracilipes and vice versa. In general, interspecific interactions are important for determining the structure of communities (Chase \& Leibold, 2003; Arnan et al. 2011) because they can affect the behaviour of species, as well as alter the dominance relationships in the community (Andersen, 2000; Parr, 2008; Segev \& Ziv, 2012). Usually, there are one or more dominant species that influence the ant communities and, thus, ecological processes, either by direct behavioral interactions such as territoriality or aggressiveness, or through exploitation of resources (by numerically dominant species; Davidson, 1998; Parr \& Gibb, 2010).

The two invasive species $S$. geminata and $A$. gracilipes are the most dominant ground-foraging species in our study sites. Both species are known for interspecific aggression, as well as being fast recruiting and occurring in high numbers. Although we did not explicitly assess the interaction between different species and the effect of competition on ant community structure, the low cooccurrence of the three species at the baits suggests that the species tend to avoid encounters with each other. Of these species, at least the two invasive species are ecologically equivalent species, providing the same functions to the ecosystem through a similar diet and foraging system. Because we never found the same species on the same plot without an effect on seed predation rate, it is likely that one species compensates for the functional role as seed predators of other species. We conclude that functional redundancy, where multiple species contribute to seed predation (Wohl et al. 2004) caused overall high seed predation rates without any measurable effects of the applied 
pesticide treatments.

The location of our plots within the landscape did not affect ant communities or seed predation, which is likely to be a result of the dominance of invasive species present on all plots. As is characteristic for invasive species, the two most dominant ant species $S$. geminata and $A$. gracilipes are known to favour open and disturbed habitats, such as forest edges or agricultural crops (Morrison, 1996; Perfecto \& Vandermeer, 1996). They can travel large distances or reach these areas via human transport. As a result of their omnivorous diet (characteristic for invasive species), fast recruitment and high abundances, they usually dominate and possibly alter the ant communities where they occur and, thus, they have no effect of the forest edge because alternative habitats for native species could be found.

One caveat of the present study may be an underestimation of ant species richness as a result of the sampling method; ants may have food preferences different from tuna or sugar baits. In addition, dominant species can monopolize food baits, thereby suppressing other species from suitable food sources. Seed predation, pesticides and farm income. Moreover, not all seed-eating species remove or damage seeds with the same intensity. However, our well established baiting ethod was previously shown to be effective for documenting ant communities (Wielgoss et al. 2010; Wanger et al. 2011) and we found all of the seed eating ant species on the tuna baits (see Supporting information, Table S2). The dominance of invasive ants in our gardens is common for disturbed tropical areas. Invasive ants have been found to remove and predate on seeds and can thus change the seed assemblage merely as a result of high numbers (Rodriguez-Cabal et al. 2012).

\section{GENERAL EFFECTS OF PESTICIDES ON ANTS}

Although pesticide effects on ants in agroecosystems vary greatly depending on the type of pesticide and the species considered (Wilson et al. 1999; Pereira et al. 2005; Greenslade et al. 2010), several studies have reported a lack of response in ants to sprayed chemicals (Wang et al. 2000; MichereffFilho et al. 2002; Matlock \& de la Cruz, 2003; Kwon et al. 2005). Others have found a significant reduction of ant diversity and abundances in agroecosystems treated with pesticides (Perfecto, 1990; Matlock \& de la Cruz, 2003; Pereira et al. 2005) or herbicides (Sonoda et al. 2011). Insecticides do not affect all ant species equally (Michereff-Filho et al. 2002; Badji et al. 2006) or lead to the dominance of a small number of ant species (Perfecto, 1990; Roth et al. 1994; Perfecto \& Snelling, 1995; Baraibar et al. 2011). Together with the results reported in the present study, this strongly suggests that the application of pesticides to reduce harvester ant populations is not an effective management practice. Spraying insecticides targets only those worker ants on the soil surface 
and not the queen and, hence, the survival and growth of the colony (Cerdan, 1989). Ineffective pesticide application not only has implications for seed protection, but also suggests that, if invasive ant species are not controlled by pesticides, there are implications for crop production because these ants might act as a pests directly on crops (e.g. protecting sap-sucking insects; Behera et al. 2001) by culling parasitized Homoptera (Ness \& Bronstein, 2004) or by introducing diseases (Clough et al. 2010; Wielgoss et al. 2012).

In Indonesia, pesticides are extremely frequently applied with almost no control standards (e.g. the WHO categorized 44\% of the active ingredients in pesticides currently applied in Indonesia as extremely, highly or moderately hazardous; Kishi et al. 1995) posing significant threats to health and the environment (Lacher \& Goldstein, 1997; Kwok et al. 2007; Noegrohati et al. 2008; Kesavachandran et al. 2009; Daam \& Van den Brink, 2010). Therefore, pesticides either have to be applied more target specific in integrated pest management programmes (Food and Agriculture Organization, 1979) or entirely replaced by environmentally friendly and more sustainable practices.

Our conclusions are based on the use of pesticides for seed predation reduction, although other benefits from these treatments (e.g. the use of herbicide to control weed pressure) were not included in the present study.

\section{IMPACT OF SEED PREDATION ON INCOME OF LOCAL FARMERS}

Our results showed that the net income of farmers was just above or below the double investment threshold at which the farmers' expenses are compensated for both the current and the next growing season. Low crop prices will cause net incomes to drop below the necessary investment threshold. Moreover, seed predation varied between crop species with a different pay off. Presumably because ants often prefer smaller over larger seeds (Ready \& Vinson, 1995), large C. sativus seeds were slightly less affected by seed predation than the other seed species tested. Because $C$. sativus is a fast-yielding crop, it can generate income at a fast rate. On the other hand, the market price of $C$. sativus is far below that of strongly affected $C$. frutescens (C. sativus $0.22-0.45 \mathrm{US} \$ / \mathrm{kg}$; $C$. frutescens 1.30-11.65 US\$/kg; I. Motzke, personal communication; Chatterjee, 2011). Depending on the sensitivity of the crops to pests, crop prices and price fluctuations, farmers need to decide on what crop species to grow and the associated management practices. By growing more than one crop species at the same time (multi-cropping agriculture), farmers can buffer changes in crop prices and pests. 


\section{SEED PROTECTION AND MANAGEMENT RECOMMENDATIONS}

Other possible pest control practices in addition to the use of pesticides may be: (i) targeted chemical seed protection; (ii) seed burial; (iii) nursery stations; and (iv) over-seeding to increase seed survival. Although we found that seed coating and spraying of insecticides was not effective in avoiding seed predation by ants, farmers in our study area often use additional strong toxic chemicals to protect seeds such as the most commonly used insecticide, carbofuran (highly hazardous WHO Class Ib; WHO, 2009), which is applied directly onto the seeds. It is, however, forbidden in most western countries (e.g. the European Union and Canada; in the U.S.A., it is only used on crops not grown for human consumption) because of its high toxicity to humans and nontarget fauna, and high persistence in the environment (Sánchez-Moreno et al. 2009).

A more sustainable seed protection practice than currently recommended is to reduce ant seed predation by covering the seeds with soil (Carroll \& Risch, 1983; Nilson \& Hjältén, 2003). However, S. geminata was found to remove seeds even at a depth of $7.5 \mathrm{~cm}$ (Chang \& Ota, 1976; Trabanino et al. 1989). Another practice that is feasible for $C$. frutescens and S. melongena may be to pre-grow the plants in seedbeds and then transplant them to the fields (Basedow et al. 2005). However, this method is more labour intensive and farmers also need to invest in inputs because the seeds and seedlings also require protection from ants in the nursery. Special precaution for human and livestock is necessary if nurseries are near the homestead and chemicals such as carbofuran are used for seed protection. Other less harmful (e.g. organic) insecticides should be used/developed to mitigate risks for human health. In addition, the method is unsuitable for C. sativus and D. carota seeds because these crops are better sown directly into the field (I. Motzke, personal communication).

Overseeding is an effective method in agricultural areas with a high seed predation risk to overcome seed loss, where farmers sow at least double the amount of seeds to increase germination success (Litsinger et al. 2003). This practice is environmentally friendly because it preserves biocontrol services by native predatory ant species (Armbrecht \& Philpott, 2006; Wanger et al. 2011) and one additional package of seeds costs $\$ 0.50$ (this is less than the amount for a packet of cigarettes; I. Motzke, personal communication with farmers) more than an additional package of stronger insecticides (e.g. carbofuran). Overseeding was also recommended to overcome seed loss in rice in the Philippines (Litsinger et al. 2009). In natural ecosystems, overseeding is a process where some plant species react with mast seeding to enhance the amount of germinating seeds (Kelly \& Sork, 2002). However, this effect might be limited by increased worker recruitment by ants if farmers apply overseeding at high and frequent intervals, and thus might diminish the effect of 
providing many seeds at once. Hence, overseeding as a biodiversity-friendly pest control possibility needs further research.

Although we report the strong effects of seed predation on crop yield and income with potential management implications, this topic is worthy of additional research. Future studies should focus on the ecology of the seed-predating ant species involved; test management recommendations such as overseeding; and conduct ecotoxicological studies on ant sensitivity to pesticide application.

\section{ACKNOWLEDGEMENTS}

We thank RISTEK for issuing the research permit (No. 0048/EXT/SIP/FRP/SM/X/2010) and our Indonesian counterpart Shahabuddin Saleh for administrative help. We are indebted to our Indonesian assistants in the field; Arno Wielgoss and Dirk Mezger for help with general advice on ants; and Roland Olschewski and Gesine Pufal for help with the manuscript. I. M. received financial support from the German Academic Exchange Service. T. C. W. was funded through an Endeavour International Postgraduate scholarship, a University of Adelaide scholarship and a University of Lüneburg Post Doctoral fellowship. A. M. K. and T. T. received funding from the German Science Foundation (DFG, KL 1849/10-1 and TS 45/32-1). This article is in memory of our mentor and colleague Navjot Sodhi, who died in June 2011 and is missed dearly.

\section{REFERENCES}

Adams, C.T., Banks, W.A., Lofgren, C.S., Smittle, B.J. \& Harlan, D.P. (1983) Impact of the red imported fire ant, Solenopsis invicta (Hymenoptera: Formicidae), on the growth and yield of soybeans. Journal of Economic Entomology, 76, 1129-1132.

Albert, M.J., Escudero, A. \& Iriondo, J.M. (2005) Assessing ant seed predation in threatened plants: a case study. Acta Oecologica, 28, 213-220.

de Almeida, A., do Couto, H.T.Z. \& de Almeida, A.F. (2010) Are camouflaged seeds less attacked by wild birds? Scientia Agricola, 67, 170-175.

Andersen, A.N. (2000) Global ecology of rainforest ants. Functional groups in relation to environmental stress and disturbance. Ants: Standard Methods for Measuring and Monitoring Biodiversity (ed. by D. Agosti, J. D. Majer, L. E. Alonso and T. R. Schultz), pp 25-34. Smithsonian Institution Press, Washington, District of Columbia.

Anderson, D.R. (2007) Model Based Inference in the Life Sciences: A Primer on Evidence. Springer, Germany. 
Armbrecht, I. \& Philpott, S.M. (2006) Biodiversity in tropical agroforests and the ecological role of ants and ant diversity in predatory function. Ecological Entomology, 31, 369-377.

Arnan, X., Gaucherel, C. \& Andersen, A.N. (2011) Dominance and species co-occurrence in highly diverse ant communities: a test of the interstitial hypothesis and discovery of a three-tiered competition cascade. Oecologia, 166, 783-794.

Badji, C.A., Guedes, R.N.C., Correa, A.S., Ferreira, G.H. \& Nascimento, I.C. (2006) Deltamethrininduced impact on ant assemblages in tropical maize fields under conventional and notillage cultivation. Sociobiology, 48, 701-715.

Baraibar, B., Ledesma, R., Royo-Esnal, A. \& Westerman, P.R. (2011) Assessing yield losses caused by the harvester ant Messor barbarus (L.) in winter cereals. Crop Protection, 30, 1144-1148.

Basedow, T., Waruwu, Y. \& Arinafril (2005) The epigeal predatory arthropods in aubergine fields at South Sumatra Indonesia with regard to the plant cover and the use of insecticides. Zeitschrift für Pflanzenkrankheiten und Pflanzenschutz - Journal of Plant Diseases and Protection, 112, 573-579.

Bawa, K.S., Kress, W.J., Nadkarni, N.M. et al . (2004) Tropical ecosystems into the 21st century. Science, 306, 227-228.

Behera, M.K., Behera, R. \& Patro, B. (2001) Observations on the honeydew excretion and ant attendance in the common chrysanthemum aphid, Macrosiphoniella sanborni. Plant Protection Bulletin, 53, 1-2.

Brittain, C.A., Vighi, M., Bommarco, R., Settele, J. \& Potts, S.G. (2010) Impacts of a pesticide on pollinator species richness at different spatial scales. Basic and Applied Ecology, 11, $106-115$.

Carroll, C.R. \& Risch, S.J. (1983) Tropical annual cropping systems: ant ecology. Environmental Management, 7, 51-57.

Cerdan, P. (1989) Etude de la biologie, de l'ecologie et du comportament des fourmis moissonneuses du genre Messor (Hymenoptera, Formicidae) en Crau. PhD Thesis, Universit'e de Provence.

Chang, V.C.S. \& Ota, A.K. (1976) Fire ant (Hymenoptera, Formicidae) amage to polyethylene tubing used in drip irrigation systems. Journal of Economic Entomology, 69, 447-450.

Chase, J.M. \& Leibold, M.A. (2003) Ecological Niches. University of Chicago Press, Chicago, Illinois.

Chatterjee, N. (2011) Indonesia calls for planting chilies to avoid hot inflation. The Straits Times, Singapore, Reuters [WWW document]. URL http://in.reuters.com/article/2011/01/06/ idINIndia-53965520110106 [accessed on 15 September 2011]. 
Chiverton, P.A. \& Sotherton, N.W. (1991) The effects on beneficial arthropods of the exclusion of herbicides from cereal crop edges. Journal of Applied Ecology, 28, 1027-1039.

Clough, Y., Abrahamczyk, S., Adams, M.-O. et al . (2010) Biodiversity patterns and trophic interactions in human dominated tropical landscapes in Sulawesi (Indonesia): plants, arthropods and vertebrates. Tropical Rainforests and Agroforests Under Global Change. Ecological and Socio-Economic Valuation (ed. by T. Tscharntke, C. Leuschner, E. Veldkamp, H. Faust, E. Guhardja and A. Bidin), pp. 15-71. Springer-Verlag, Germany.

Daam, M.A. \& Van den Brink, P.J. (2010) Implications of differences between temperate and tropical freshwater ecosystems for the ecological risk assessment of pesticides. Ecotoxicology, 19, 24-37.

Davidson, D.W. (1998) Resource discovery versus resource domination in ants: a functional mechanism for breaking the trade-off. Ecological Entomology, 23, 484-490.

Dias, J.C.D. (2010) Impact of improved vegetable cultivars in overcoming food insecurity. Euphytica, 176, 125-136.

Drees, B.M., Berger, L.A., Cavazos, R. \& Vinson, S.B. (1991) Factors affecting soybean and corn seed predation by foraging red imported fire ant (Hymenoptera: Formicidae). Journal of Economic Entomology, 84, 285-289.

Edwards, C.A. (1991) Long term ecological effects of herbicides: field studies. Proceedings of the Brighton Crop Protection Conference, Weeds, 2, 883-890. British Crop Protection Council, Great Britain.

Ewald, J.A. \& Aebischer, N.J. (2000) Trends in pesticide use and efficacy during 26 years of changing agriculture in southern England. Environmental Monitoring and Assessment, 64, 493-529.

FAO (1979) Guidelines for Integrated Control of Rice Insect PestsFAO Plant Production and Protection Paper No. 14. Food and Agriculture Organization, Italy.

Foley, J.A., DeFries, R., Asner, G.P. et al . (2005) Global consequences of land use. Science, 309, $570-574$.

Foley, J.A., Ramankutty, N., Brauman, K.A. et al . (2011) Solutions for a cultivated planet. Nature, 478, 337-342.

Greenslade, P.J.M., Reid, I.A. \& Packer, I.J. (2010) Herbicides have negligible effects on ants and springtails in an Australian wheat field. Soil Biology and Biochemistry, 42, 1172-1175.

Hobbs, P.R. (2007) Conservation agriculture: what is it and why is it important for future sustainable food production? Journal of Agricultural Science, 145, 127-137.

Hulme, P.E. \& Kollmann, J. (2004) Seed predator guilds, spatial variation in post-dispersal seed 
predation and potential effects on plant demography: a temperate perspective. Predation, Dispersal and Seedling Establishment (ed. by P. M. Forget, J. E. Lambert, P. E.

Hulme and S. B Vander Wall), pp. 9-30. CAB International, U.K. Johns, G.G. \& Greenup, L.R. (1976) Predictions of likely theft by ants of oversown seed for the Northern Tablelands of New South Wales. Australian Journal of Experimental Agriculture, 16, 257-264.

Kelly, D. \& Sork, V.L. (2002) Mast seeding in perennial plants: why, how, where? Annual Review of Ecology and Systematics, 33, 427-447.

Kelman, W.M., Lodge, G.M. \& Culvenor, R.A. (2002) Influence of panicle fragment size on ant seed-harvesting and seedling recruitment in Phalaris aquatica. Australian Journal of Experimental Agriculture, 42, 571-579.

Kesavachandran, C.N., Fareed, M., Pathak, M.K., Bihari, V., Mathur, N. \& Srivastava, A.K. (2009) Adverse health effects of pesticides in agrarian populations of developing countries. Reviews of Environmental Contamination and Toxicology, 200, 33-52.

Kishi, M., Hirschhorn, N., Djajadisastra, M., Satterlee, L.N., Strowman, S. \& Dilts, R. (1995) Relationship of pesticide spraying to signs and symptoms in Indonesian farmers. Scandinavian Journal of Work, Environment \& Health, 21, 124-133.

Kwok, K.W.H., Leung, K.M.Y., Lui, G.S.G. et al . (2007) Comparison of tropical and temperate freshwater animal species' acute sensitivities to chemicals: implications for deriving safe extrapolation factors. Integrated Environmental Assessment and Management, 3, 49-67.

Kwon, T.S., Song, M.Y., Shin, S.C. \& Park, Y.S. (2005) Effects of aerial insecticide sprays on ant communities to control pine wilt disease in Korean pine forests. Applied Entomology and Zoology, 40, 563-574.

Lacher, T.E. \& Goldstein, M.I. (1997) Tropical ecotoxicology: status and needs. Environmental Toxicology and Chemistry, 16, 100-111.

Litsinger, J.A., Libetario, E.M. \& Barrion, A.T. (2003) Early planting and overseeding in the cultural control of rice seedling maggot Atherigona oryzae Malloch in the Philippines. International Journal of Pest Management, 49, 57-69.

Litsinger, J.A., Libetariob, E.M., Barrionb, A.T. \& Apostol, R.P. (2009) Comparison of insect pest complexes in different Philippine dryland rice environments: population densities, yield loss, and management. International Journal of Pest Management, 55, 129-149.

Lynn, D.J., Thomas, A., Best, N. \& Spiegelhalter, D. (2000) WinBUGS - a Bayesian modelling framework: concepts, structure, and extensibility. Statistics and Computing, 10, 325-337. MacMahon, J.A., Mull, J.F. \& Crist, T.O. (2000) Harvester ants (Pogonomyrmex spp.): their 
community and ecosystem influences. Annual Review of Ecolology and Systematics, 31, $265-291$.

Marshall, D.L., Beattie, A.J. \& Bollenbacher, W.E. (1979) Evidence for diglycerides as attractants in an ant-seed interaction. Journal of Chemical Ecology, 5, 335-344.

Matlock, R.B. \& de la Cruz, R. (2003) Ants as indicators of pesticide impacts in banana. Environmental Entomology, 32, 816-829.

Michereff-Filho, M., Della Lucia, T.M.C., Cruz, I., Guedes, R.N.C. \& Galvao, J.C.C. (2002) Chlorpyrifos spraying of no-tillage corn during tasselling and its effect on damage by Helicoverpa zea (Lep., Noctuidae) and on its natural enemies. Journal of Applied Entomology, $126,422-430$.

Monsanto (2010) Supplemental Toolkit for Investors. Monsanto, [WWW document]. URL http://www.monsanto.com/investors/ documents/supplemental_toolkit.pdf [accessed on 22 October 2011].

Morrison, L.W. (1996) Community organization in a recently assembled fauna: the case of Polynesian ants. Oecologia, 107, 243-256.

Morrison, J.E., Williams, D.F., Oi, D.H. \& Potter, K.N. (1997) Damage to dry crop seed by red imported fire ant (Hymenoptera: Formicidae). Journal of Economic Entomology, 90, $218-222$.

Munkvold, G.P. (2009) Seed pathology progress in academia and industry. Annual Review of Phytopathology, 47, 285-311.

Ness, J.H. \& Bronstein, J.L. (2004) The effects of invasive ants on prospective ant mutualists. Biological Invasions, 6, 445-461.

Nilson, M.E. \& Hj”alt'en, J. (2003) Covering pine-seeds immediately after seeding: effects on seedling emergence and on mortality through seed-predation. Forest Ecology and Management, 176, 449-457.

Noegrohati, S., Narsito, Hadi, S. \& Sanjayadi (2008) Fate and behavior of organochlorine pesticides in the Indonesian tropical climate: a study in the Segara Anakan estuarine ecosystem. CleanSoil Air Water, 36, 767-774.

Parr, C.L. (2008) Dominant ants can control assemblage species richness in a South African savanna. Journal of Animal Ecology, 77, 1191-1198.

Parr, C.L. \& Gibb, H. (2010) Competition and the role of dominant ants. Ant Ecology (ed. by L. Lach, C. L. Parr and K. L. Abbott), pp 77-96. Oxford University Press, New York, New York. 
Pereira, J., da Silva, A., PicanC s co, M., Barros, E. \& Jakelaitis, A. (2005) Effects of herbicide and insecticide interaction on soil entomofauna under maize crop. Journal of Environmental Science and Health - Part B: Pesticides, Food Contaminants, and Agricultural Wastes, 40, $45-54$.

Perfecto, I. (1990) Indirect and direct effects in a tropical agroecosystem: the maize-pest-ant system in Nicaragua. Ecology, 71, 2125-2134.

Perfecto, I. \& Snelling, R. (1995) Biodiversity and the transformation of a tropical agroecosystem: ants in coffee plantations. Ecological Applications, 5, 1084-1097.

Perfecto, I. \& Vandermeer, J. (1996) Microclimatic changes and the indirect loss of ant diversity in tropical agroecosystems. Oecologia, 108, 577-582.

Perfecto, I. \& Vandermeer, J. (2010) The agroecological matrix as alternative to the land-sparing/ agriculture intensification model. Proceedings of the National Academy of Sciences of the United States of America, 107, 5786-5791.

R Development Core Team (2010) R: A Language and Environment for Statistical Computing. R Foundation for Statistical Computing, Austria[WWW document]. URL http://www.Rproject.org [accessed on 7 March 2012].

Ready, C.C. \& Vinson, S.B. (1995) Seed selection by the red imported fire ant (Hymenoptera: Formicidae) in the laboratory. Environmental Entomology, 24, 1422-1431.

Rodriguez-Cabal, M.A., Stuble, K.L., Guenard, B., Dunn, R.R. \& Sanders, N.J. (2012) Disruption of ant-seed dispersal mutualisms by the invasive Asian needle ant (Pachycondyla chinensis). Biological Invasions, 14, 557-565.

Roth, D.S., Perfecto, I. \& Rathcke, B. (1994) The effects of management systems on groundforaging ant diversity in Costa Rica. Ecological Applications, 3, 423-436.

Sánchez-Moreno, S., Alonso-Prados, E., Alonso-Prados, J.L. \& García- Baudín, J.M. (2009) Multivariate analysis of toxicological and environmental properties of soil nematicides. Pest Management Science, 65, 82-92.

Segev, U. \& Ziv, Y. (2012) Consequences of behavioral vs. numerical dominance on foraging activity of desert seed-eating ants. Behavioral Ecology and Sociobiology, 66, 623-632.

Skidmore, B. \& Heithaus, E.R. (1988) Lipid cues for seed-carrying ants in Hepatica americana. Journal of Chemical Ecology, 14, 2185-2196.

Sonoda, S., Izumi, Y., Kohara, Y., Koshiyama, Y. \& Yoshida, H. (2011) Effects of pesticide practices on insect biodiversity in peach orchards. Applied Entomology and Zoology, 46, 335-342.

Sturtz, S., Ligges, U. \& Gelman, A. (2005) R2WinBUGS: a package for running WinBUGS from 
R. Journal of Statistical Software, 12, 1-16.

Trabanino, C.R., Pitre, H.N., Andrews, K.L. \& Meckenstock, D.H. (1989) Effect of seed size, color and number of seeds per hill and depth of planting on sorghum seed survival and stand establishment: relationship to phytophagous insects. Pest Management Science, 66, $225-229$.

Vander Wall, S.B., Kuhn, K.M. \& Beck, M.J. (2005) Seed removal, seed predation, and secondary dispersal. Ecology, 86, 801-806.

Van Rheenen, T., Elbel, C., Schwarze, S., Nuryartono, N., Zeller, M. \& Sanim, B. (2004) Encroachments on primary forest: are they really driven by despair? Land Use, Nature Conservation and the Stability of Rain Forest Margins in Southeast Asia (ed by. G. Gerold, M. Fremerey and E. Guhardja), pp. 199-213. Springer, Germany.

Véle, A., Holusa, J. \& Frouz, J. (2009) Sampling for ants in differentaged spruce forests: a comparison of methods. European Journal of Soil Biology, 45, 301-305.

Wang, C.L., Strazanac, J. \& Butler, L. (2000) Abundance, diversity, and activity of ants (Hymenoptera: Formicidae) in oak-dominated mixed Appalachian forests treated with microbial pesticides. Environmental Entomology, 29, 579-586.

Wanger, T.C., Rauf, A. \& Schwarze, S. (2010) Pesticides and tropical biodiversity. Frontiers in Ecology and the Environment, 4, 178-179.

Wanger, T.C., Wielgoss, A.C., Motzke, I., Clough, Y., Brook, B.W., Sodhi, N.S. \& Tscharntke, T. (2011) Endemic predators, invasive prey, and native diversity. Proceedings of the Royal Society of London Series B, Biological Sciences, 278, 690-694.

WHO (2009) The WHO Recommended Classification of Pesticides by Hazard and Guidelines to Classification 2009. World Health Organization, International Programme on Chemical Safety, Switzerland[WWW document]. URL http://www.who.int/ ipcs/publications/ pesticides_hazard_2009.pdf [accessed on 26 October 2011].

Wielgoss, A., Tscharntke, T., Buchori, D., Fiala, B. \& Clough, Y. (2010) Temperature and a dominant dolichoderine ant species affect ant diversity in Indonesian cacao plantations. Agriculture, Ecosystems \& Environment, 135, 253-259.

Wielgoss, A., Clough, Y., Fiala, B., Rumede, A. \& Tscharntke, T. (2012) A minor pest reduces yield losses by a major pest: plantmediated herbivore interactions in Indonesian cacao. Journal of Applied Ecology, 49, 465-473.

Wilson, J.D., Morris, A.J., Arroyo, B.E., Clark, S.C. \& Bradbury, R.B. (1999) A review of the abundance and diversity of invertebrate and plant foods of granivorous birds in northern 
Europe in relation to agricultural change. Agriculture, Ecosystems \& Environment, 75, $13-30$

Wohl, D.L., Arora, S. \& Gladstone, J.R. (2004) Functional redundancy supports biodiversity and ecosystem function in a closed and constant environment. Ecology, 85, 1534-1540.

Yardim, E.N. \& Edwards, C.A. (2002) Effects of weed control practices on surface-dwelling arthropod predators in tomato agroecosystems. Phytoparasitica, 30, 379-386.

\section{SUPPORTING INFORMATION}

\section{File S1 - NeT INCOME AND COST CALCULATION OF SEED PREDATION}

We calculated net income from all crop species cucumber (Cucumis sativus), carrot (Daucus carota), chili pepper (Capsicum frutescens) and eggplant (Solanum melongena); hereafter "crops") based on two standardized questionnaires and experimental data (Motzke unpublished) on yield, prices and farm expenses for an area of $300 \mathrm{~m}^{2}$. The questionnaire $(\mathrm{n}=30)$ included questions about plant species use, yield ( $\mathrm{kg}$ and/or pieces harvested per land area), expenses and operational costs (i.e., cost for land preparation, pesticides and fertilizer application and costs), as well as net revenues (sales prices and income) of the crop species (Questionnaire S2 for the questions relevant for this study).

The experimental data include number of fruits and weight of fruits per plant species of 60 cucumber and eggplant individuals each. According to the local management practices, we treated the crop plants with fertilizer, insecticides and herbicides every week. We compared the values on crop yield from our experimental data to the information on crop yield from the questionnaires to derive a standard measure for the calculation of net income (Table S1). Yield data on carrot and chili, as well as prices for expenses, were estimated from the interviews and according to common farm practice for an area of $300 \mathrm{~m}^{2}$

For each plant individual, we calculated income from mean yield per plant (i.e. average number of fruits and fruit weight per plant) and prices per kg. We subtracted operational costs (i.e. recurring expenses for farmers) according to the percentage of plant individuals successfully grown (\% of seed predation). We also include operational costs for fertilizer, pesticides and labor costs. For fertilizer and pesticide costs, we calculated a value on a per-individual plant basis, because fertilizer and pesticides are commonly applied to individual plants by hand. Labor costs (for weeding, pesticide spraying and harvest) were calculated based on the time that a farmer has to spend on the plantation and the expected salary for work elsewhere. 
As a conservative measure, we assumed a linear relationship between the percentage of seeds removed and net income. This is because each removed seed results in a loss of an entire plant decreasing total net income. To calculate net income, we added a linearly increasing value for the number of plant individuals grown on an area of $300 \mathrm{~m} 2$. We started with the initial costs (land preparation, seeds, and herbicides) and subtracted the corresponding operational costs.

Compensatory plant growth responses (i.e. increased plant size and yield if fewer plant individuals are grown) are not included, because we assumed that farmers grow plant individuals in optimal distances.

\section{Supplementary Figure 1}
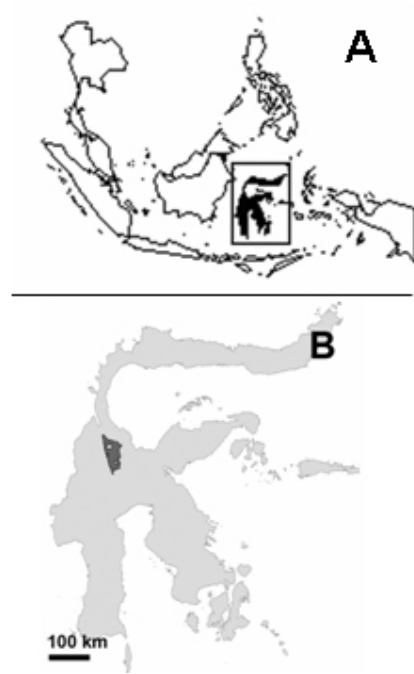

Figure S1. Location of our study area in Southeast Asia (A); Sulawesi (B); Study area (C) (modified from Wanger et al. 2011); Gardens with distance to forest classified in three categories; black: 0-100; grey: >100-1000; light gray: >1000-2500 m (D) 


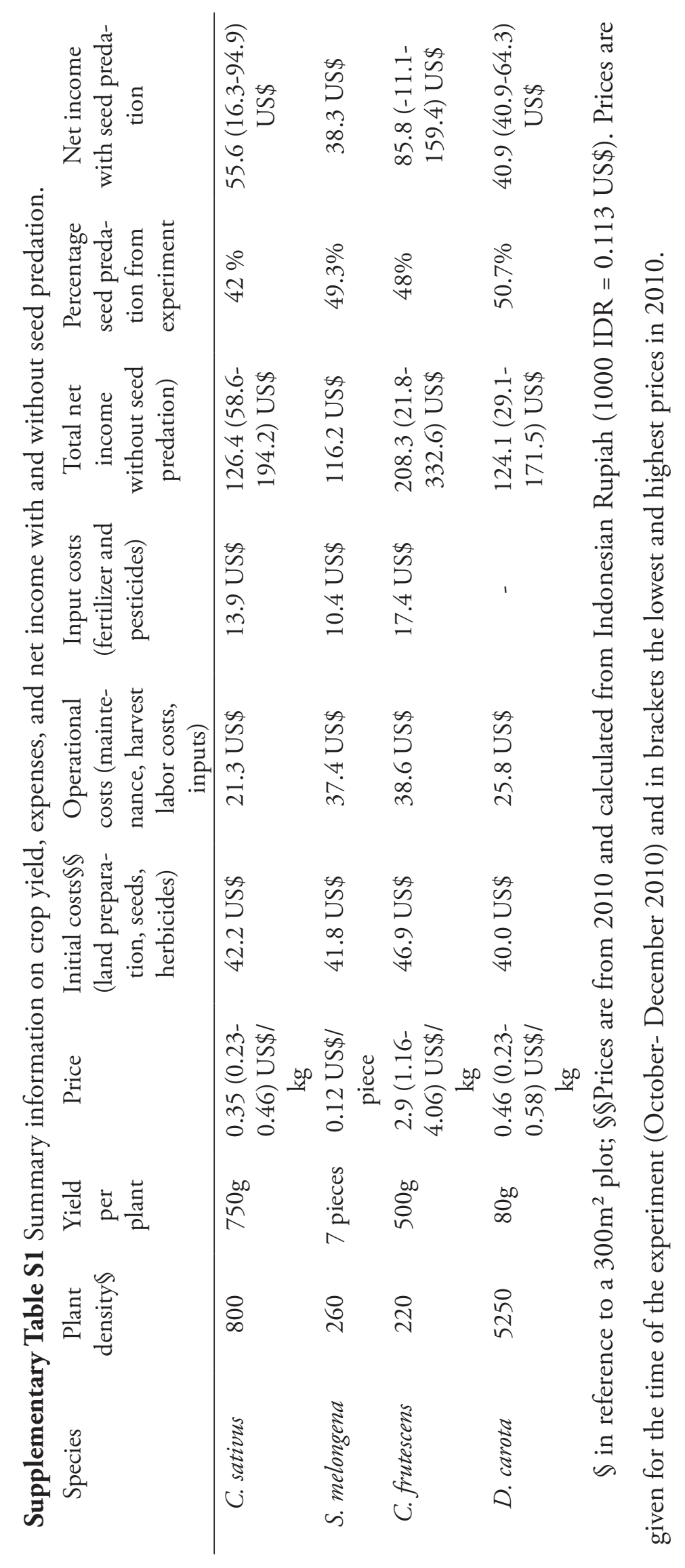




\section{File S2 - Socio-eCONOMIC QUeSTIONNAIRE}

Presented are only questions important for this study from two standardized questionnaires conducted with the garden owners in 2010. Some questions, like on information about harvest, were re-formulated for the second questionnaire.

\section{Questionnaire}

1) Make a list of the most important sources of income / principal in your household in the past year.

Sequence The main work this Type of contract Days worked Total salary Total

sources of year Code 2 in one week? (IDR/day / salary

income Code 1 month) (IDR/

\section{Code 1: 1=Self-employed in agriculture \\ $8=$ Student; $2=$ Self-employed in non-farm enterprise;} $3=$ Official; $4=$ Casual worker; $5=$ Salaried worker in agriculture; $6=$ Salaried worker in non-agriculture; $8=$ student; $9=$ unemployed to look for work; $10=$ retired; $11=$ cannot work, disability

Code 2: $1=$ daily wage; $2=$ per week/monthly; $3=$ contract; $4=$ no contract or salary; $5=$ total revenue/ harvest; $6=$ other.

2) Current possession of land (land owned at present)

Please fill out for each parcel of land owned.

\begin{tabular}{|c|c|c|c|c|c|c|c|}
\hline $\begin{array}{c}\text { Code } \\
\text { of } \\
\text { plot }\end{array}$ & $\begin{array}{c}\text { Description } \\
\text { Area } \\
\text { (ares) }\end{array}$ & $\begin{array}{c}\text { Type } \\
\text { of agricul- } \\
\text { tural land }\end{array}$ & $\begin{array}{c}\text { Current land } \\
\text { use }(1 ., 2 ., 3 . \\
\text { crop) } \\
\text { Code } 2\end{array}$ & $\begin{array}{c}\text { If } 3 \text { or } 4 \\
\text { (coffee/co- } \\
\text { coa) age in } \\
\text { years }\end{array}$ & $\begin{array}{l}\text { Quality } \\
\text { of soil } \\
\text { Code } 4\end{array}$ & $\begin{array}{c}\begin{array}{c}\text { Agro- } \\
\text { forestry? } \\
1=\text { Yes, } \\
2=\mathrm{No}\end{array}\end{array}$ & $\begin{array}{c}\text { Distance } \\
\text { field-house } \\
\text { in walking } \\
\text { minutes }\end{array}$ \\
\hline 1 & ......... & .......... & .......... & $\ldots$ & $\cdots$ & .. & \\
\hline 2 & ........ & .......... & .......... & .......... & .......... & $\cdots$ & \\
\hline 3 & $\ldots \ldots \ldots$ & .......... & .......... & .......... & .......... & .......... & $\cdots$ \\
\hline 4 & $\ldots \ldots \ldots$ & $\ldots \ldots \ldots$ & $\ldots \ldots \ldots$ & $\ldots \ldots \ldots$ & ......... & $\ldots \ldots \ldots$ & $\ldots \ldots \ldots$ \\
\hline 5 & ........ & .......... & ......... & .......... & .......... & .......... & .......... \\
\hline
\end{tabular}

Code 1:1=Homegarden; 2=Rice field with simple irrigation; $3=$ Rice field with semi-technical irrigation; $4=$ Rice field with technical irrigation; $5=$ dry fields in the valley; $6=$ upland dry fields; $7=$ Garden in the forest; $8=$ Non-agricultural land; $9=$ Primary forest Code 2: 1=Rice field; 2=Maize; 3=Cocoa; 4=Coffee; 5=Peanuts; 6=Bananas; 7=Garden in the forest; $7=$ Coconuts; $8=$ Cassava; 10=Beans; 11=Other vegies; $12=$ =Avocados; $13=$ =Pasture; 14=Bushes/Fallow; 15=Secondary forest; 16=Don't know; 17=Others (write): 
Code 3: 1=Local variety; 2=Improved variety; 3=Recycled seeds

Code 4: 1=Fertile soils; 2=Medium-fertile soils; 3=Less-fertile soils

\section{3) Plot information}

Note for enumerator: the next questions refer only to the last crop harvested (annual crops) and to the last twelve months for all perennial crops respectively.

\begin{tabular}{|c|c|c|c|c|c|c|}
\hline $\begin{array}{c}\text { Code } \\
\text { of } \\
\text { plot }\end{array}$ & $\begin{array}{c}\text { Month of } \\
\text { planting }\end{array}$ & $\begin{array}{l}\text { Quantity } \\
\text { harvested }\end{array}$ & Unit Code 2 & $\begin{array}{c}\text { How was } \\
\text { the yield? } \\
\text { Code } 3\end{array}$ & $\begin{array}{l}\text { Cost for land } \\
\text { preparation }\end{array}$ & $\begin{array}{c}\text { Value received } \\
\text { (IDR) }\end{array}$ \\
\hline 1 & ........ & ......... & .......... & ... & .. & \\
\hline 2 & $\ldots \ldots \ldots$ & $\ldots \ldots \ldots$ & .......... & .......... & .......... & $\cdots$ \\
\hline 3 & ........ & .......... & .......... & ......... & .......... & .......... \\
\hline 4 & ........ & .......... & .......... & .......... & .......... & $\ldots \ldots \ldots$ \\
\hline 5 & ........ & .......... & ......... & .......... & ......... & .......... \\
\hline
\end{tabular}

Code 1: 1=Good; $2=$ =Average; $3=$ Below average

Code 2: 1=Kilograms; 2=Liters; $3=$ Bundles; 4=Pieces; $5=$ Tandan; $6=$ Container

4) Plot-specific output and input data

The input use refers to the time before the last harvest (annuals) and to the last twelve months for all perennials respectively

\begin{tabular}{|c|c|c|c|c|c|}
\hline \multirow{2}{*}{$\begin{array}{c}\text { Code } \\
\text { of } \\
\text { plot }\end{array}$} & \multicolumn{3}{|c|}{ Chemical fertiliser use } & \multirow{2}{*}{$\begin{array}{l}\text { Do you apply organic } \\
\text { fertiliser / mulch? } \\
1=\text { yes } 2=\text { no }\end{array}$} & \multirow{2}{*}{$\begin{array}{c}\text { Costs for irrigation } \\
\text { IDR }\end{array}$} \\
\hline & Type Code 1 & $\begin{array}{c}\text { Quantity } \\
\text { bags }\end{array}$ & IDR per bag & & \\
\hline 1 & ........ & ......... & .......... & n........ & .......... \\
\hline 2 & ........ & .......... & .......... & .......... & .......... \\
\hline 3 & ........ & $\ldots \ldots \ldots$ & $\ldots \ldots \ldots$ & .......... & $\ldots \ldots \ldots$ \\
\hline 4 & ........ & .......... & .......... & n........ & .......... \\
\hline 5 & ........ & .......... & .......... & ......... & .......... \\
\hline
\end{tabular}

Code 1: $1=$ Urea; $2=$ Triple super phosphate; $3=$ ZA; $4=$ other $\ldots . . . \ldots \ldots . .$.

Code 2 : $1=\mathrm{KCL} ; 2=\mathrm{NPK} ; 3=$ other 
5) Did you use any pesticide during the last five years (2005 - 2010) ?

\begin{tabular}{|c|c|c|c|c|c|c|}
\hline $\begin{array}{l}\text { Code } \\
\text { of } \\
\text { plot }\end{array}$ & $\begin{array}{l}\text { Type of pes- } \\
\text { ticide }\end{array}$ & $\begin{array}{l}\text { Costs for } \\
\text { pesticides }\end{array}$ & $\begin{array}{c}\text { Amount of } \\
\text { pesticide }\end{array}$ & $\begin{array}{c}\text { Transport/ } \\
\text { processing } \\
\text { costs }\end{array}$ & $\begin{array}{l}\text { Labour costs: } \\
\text { paid }\end{array}$ & $\begin{array}{l}\text { soil conserva- } \\
\text { tionmeasures } \\
\text { (terracing, shad- } \\
\text { ing trees)? }\end{array}$ \\
\hline & & IDR & & IDR & IDR & $1=$ yes $2=$ no \\
\hline 1 & ........ & ......... & .......... & $\ldots$. & $\ldots$ & $\ldots$ \\
\hline 2 & ........ & ........... & .......... & .......... & ........... & .......... \\
\hline 3 & ........ & .......... & .......... & .......... & .......... & .......... \\
\hline 4 & ......... & .......... & .......... & .......... & $\ldots$ & .......... \\
\hline 5 & ........ & ......... & .......... & .......... & .......... & .......... \\
\hline
\end{tabular}

\section{Questionnaire}

\section{SPECIAL FOCUS ON CERTAIN CROP SPECIES:}

6) Have you been growing the following crops in your garden:

\begin{tabular}{|c|c|c|c|c|}
\hline Crop species & Yes [ ] No [ ] & $\begin{array}{c}\text { How many hec- } \\
\text { tare or are }\end{array}$ & $\begin{array}{c}\text { Month of } \\
\text { planting }\end{array}$ & $\begin{array}{c}\text { Month of } \\
\text { harvest }\end{array}$ \\
\hline Carrot & Yes [ ] No [ ] & & & \\
\hline Carrot for seed production & Yes [ ] No [ ] & & & \\
\hline Cucumber & Yes [ ] No [ ] & & & \\
\hline Eggplant & Yes [ ] No [ ] & & & \\
\hline Chili & Yes [ ] No [ ] & & & \\
\hline Watermelon & Yes [ ] No [ ] & & & \\
\hline Pumpkin & Yes [ ] No [ ] & & & \\
\hline Coffee & Yes [ ] No [ ] & & & \\
\hline Coffee & Yes [ ] No [ ] & & & \\
\hline
\end{tabular}

7) Input cost and income for the following crops:

\begin{tabular}{|c|c|c|c|c|}
\hline Crop species & $\begin{array}{c}\text { Amount } \\
\text { harvested } \\
\text { (Unit Code } \\
\text { 1) }\end{array}$ & $\begin{array}{l}\text { How was the } \\
\text { previous har- } \\
\text { vest Code } 2\end{array}$ & $\begin{array}{l}\text { Total cost for } \\
\text { land preparation }\end{array}$ & $\begin{array}{c}\text { Income received } \\
\text { IDR }\end{array}$ \\
\hline
\end{tabular}

(IDR)

Carrot for seed production

Cucumber

Eggplant

Chili

Watermelon

Pumpkin

Coffee

Code 1: 1=Kilograms; $2=$ Liters; $3=$ Bundles; $4=$ Pieces; $5=$ Container; $6=$ bags

Code 2: 1=Good; $2=$ Average; $3=$ Below average; $4=$ no yield 
8) What kind of work do you do in your garden throughout the year?

\begin{tabular}{ccccc} 
Work Frequency & $\begin{array}{c}\text { Last per- } \\
\text { forming }\end{array}$ & $\begin{array}{c}\text { Person work- } \\
\text { ing }\end{array}$ & $\begin{array}{c}\text { Plant species/ } \\
\text { Products }\end{array}$ & Time needed \\
\hline Hoeing & & & \\
Sowing/planting & & & \\
Fertilizing & & \\
Spraying & & \\
Weeding & & \\
Cutting trees & & \\
Harvesting & & \\
Other & & \\
\hline
\end{tabular}

9) If seeds of modern varieties would be available, would you like to replace your local varieties with the modern ones? Yes [ ] No []

Why and which species first?

List: species: $\quad$ why: 


\section{SuPPlementary Figure S2}

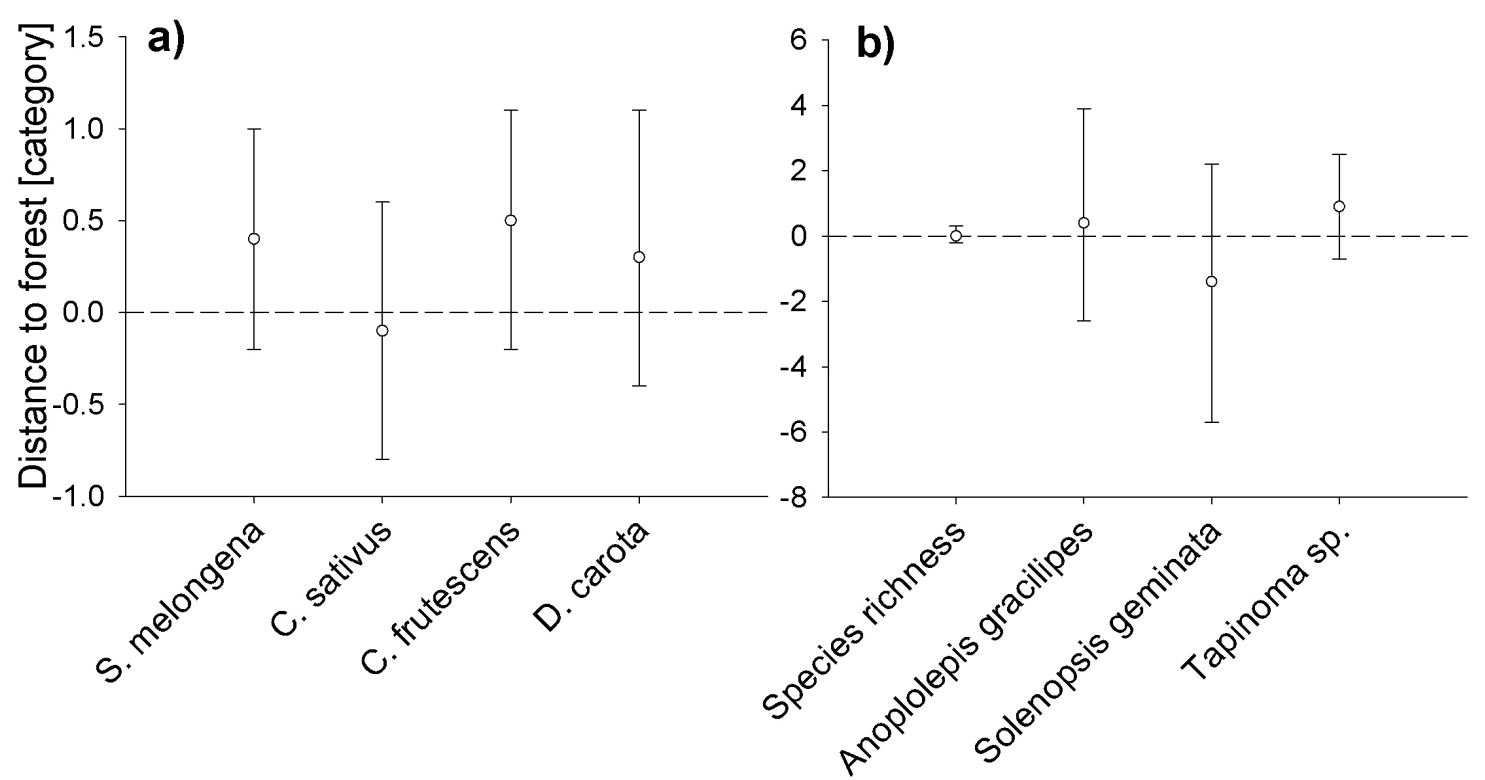

Figure S2. Effect of "distance to forest" on a) seed predation; and b) ant abundance and total ant richness. Distance to forest is in categories of $1: 0-60 \mathrm{~m} ; 2: 100-350 \mathrm{~m} ; 3: 1000-2500 \mathrm{~m}$ 


\section{SUPPLEMENTARY TABLE S2}

Table S2: List of occurrence of A. gracilipes and S. geminata on all gardens and plots for the two sampling sessions.

Sampling session 1 Sampling session 2

\begin{tabular}{|c|c|c|c|c|c|}
\hline Garden & Plots & A. gracilipes & S. geminata & A. gracilipes & S. geminata \\
\hline 1 & 1 & 0 & 0 & 0 & $\mathrm{x}$ \\
\hline 1 & 2 & 0 & $\mathrm{x}$ & 0 & $\mathrm{x}$ \\
\hline 1 & 3 & 0 & 0 & 0 & $\mathrm{x}$ \\
\hline 1 & 4 & 0 & $\mathrm{x}$ & 0 & $\mathrm{x}$ \\
\hline 2 & 1 & 0 & $\mathrm{x}$ & 0 & $\mathrm{x}$ \\
\hline 2 & 2 & 0 & $\mathrm{x}$ & 0 & $\mathrm{x}$ \\
\hline 2 & 3 & 0 & 0 & 0 & $\mathrm{x}$ \\
\hline 2 & 4 & 0 & $\mathrm{x}$ & 0 & $\mathrm{x}$ \\
\hline 3 & 1 & 0 & $\mathrm{x}$ & 0 & $\mathrm{x}$ \\
\hline 3 & 2 & 0 & $\mathrm{x}$ & 0 & $\mathrm{x}$ \\
\hline 3 & 3 & 0 & $\mathrm{x}$ & 0 & $\mathrm{x}$ \\
\hline 3 & 4 & 0 & $\mathrm{x}$ & 0 & $\mathrm{x}$ \\
\hline 4 & 1 & $\mathrm{x}$ & 0 & $\mathrm{x}$ & 0 \\
\hline 4 & 2 & $\mathrm{x}$ & 0 & 0 & 0 \\
\hline 4 & 3 & 0 & 0 & $\mathrm{x}$ & 0 \\
\hline 4 & 4 & 0 & 0 & $\mathrm{x}$ & 0 \\
\hline 5 & 1 & 0 & 0 & 0 & 0 \\
\hline 5 & 2 & 0 & 0 & 0 & 0 \\
\hline 5 & 3 & 0 & 0 & 0 & 0 \\
\hline 5 & 4 & 0 & 0 & 0 & 0 \\
\hline 6 & 1 & 0 & $\mathrm{x}$ & 0 & $\mathrm{x}$ \\
\hline 6 & 2 & 0 & $\mathrm{x}$ & 0 & $\mathrm{x}$ \\
\hline 6 & 3 & 0 & $\mathrm{x}$ & 0 & $\mathrm{x}$ \\
\hline 6 & 4 & 0 & $\mathrm{x}$ & 0 & $\mathrm{x}$ \\
\hline 7 & 1 & 0 & 0 & 0 & $\mathrm{x}$ \\
\hline 7 & 2 & 0 & 0 & 0 & $\mathrm{x}$ \\
\hline 7 & 3 & 0 & 0 & $\mathrm{x}$ & 0 \\
\hline 7 & 4 & 0 & 0 & 0 & $\mathrm{x}$ \\
\hline 8 & 1 & 0 & 0 & $\mathrm{x}$ & 0 \\
\hline 8 & 2 & 0 & 0 & 0 & 0 \\
\hline 8 & 3 & 0 & 0 & 0 & 0 \\
\hline 8 & 4 & 0 & 0 & 0 & 0 \\
\hline 9 & 1 & 0 & 0 & 0 & $\mathrm{x}$ \\
\hline 9 & 2 & 0 & 0 & 0 & $\mathrm{x}$ \\
\hline 9 & 3 & 0 & 0 & 0 & $x$ \\
\hline 9 & 4 & $x$ & 0 & 0 & $x$ \\
\hline 10 & 1 & $x$ & 0 & 0 & $\mathrm{x}$ \\
\hline
\end{tabular}




\begin{tabular}{|c|c|c|c|c|c|}
\hline \multirow[b]{2}{*}{ Garden } & \multirow[b]{2}{*}{ Plots } & \multicolumn{2}{|c|}{ Sampling session 1} & \multicolumn{2}{|c|}{ Sampling session 2} \\
\hline & & A. gracilipes & S. geminata & A. gracilipes & S. geminata \\
\hline 10 & 2 & 0 & $\mathrm{x}$ & $\mathrm{x}$ & 0 \\
\hline 10 & 3 & 0 & 0 & 0 & $\mathrm{x}$ \\
\hline 10 & 4 & 0 & $\mathrm{x}$ & 0 & $\mathrm{x}$ \\
\hline 11 & 1 & 0 & 0 & 0 & $\mathrm{x}$ \\
\hline 11 & 2 & 0 & 0 & 0 & $\mathrm{x}$ \\
\hline 11 & 3 & 0 & 0 & 0 & $\mathrm{x}$ \\
\hline 11 & 4 & 0 & 0 & 0 & $\mathrm{x}$ \\
\hline 12 & 1 & 0 & 0 & 0 & 0 \\
\hline 12 & 2 & 0 & 0 & 0 & 0 \\
\hline 12 & 3 & 0 & 0 & 0 & 0 \\
\hline 12 & 4 & 0 & 0 & 0 & 0 \\
\hline 13 & 1 & $\mathrm{x}$ & 0 & $\mathrm{x}$ & 0 \\
\hline 13 & 2 & 0 & 0 & 0 & 0 \\
\hline 13 & 3 & 0 & 0 & $\mathrm{x}$ & 0 \\
\hline 13 & 4 & 0 & 0 & 0 & 0 \\
\hline 14 & 1 & 0 & $\mathrm{x}$ & $\mathrm{x}$ & $\mathrm{x}$ \\
\hline 14 & 2 & 0 & $x$ & $x$ & 0 \\
\hline 14 & 3 & 0 & $\mathrm{x}$ & $\mathrm{x}$ & $\mathrm{x}$ \\
\hline 14 & 4 & 0 & $x$ & 0 & $x$ \\
\hline 15 & 1 & $\mathrm{x}$ & 0 & 0 & 0 \\
\hline 15 & 2 & $x$ & 0 & $\mathrm{x}$ & 0 \\
\hline 15 & 3 & 0 & 0 & $\mathrm{x}$ & 0 \\
\hline 15 & 4 & $\mathrm{x}$ & 0 & $x$ & 0 \\
\hline
\end{tabular}




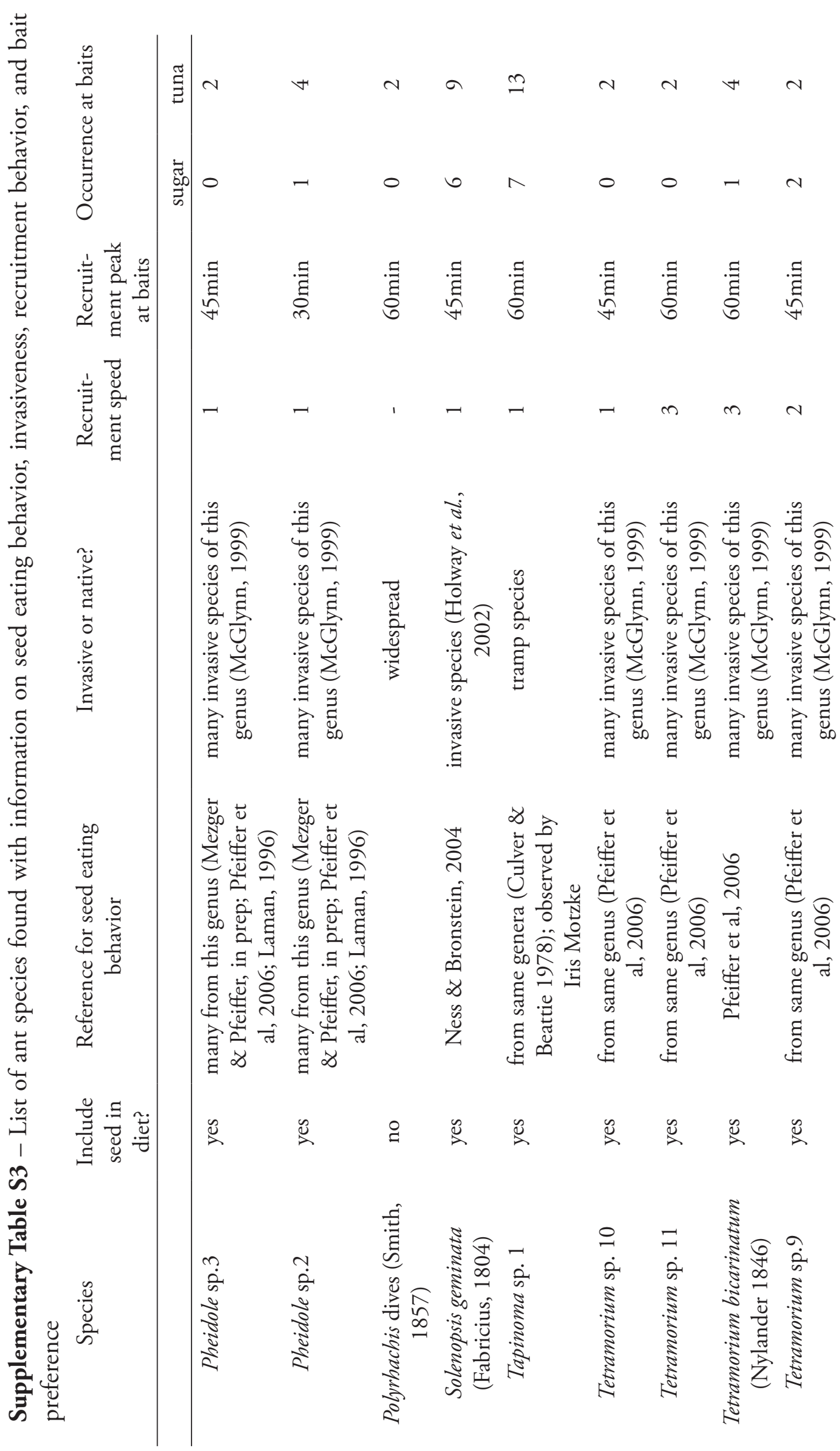




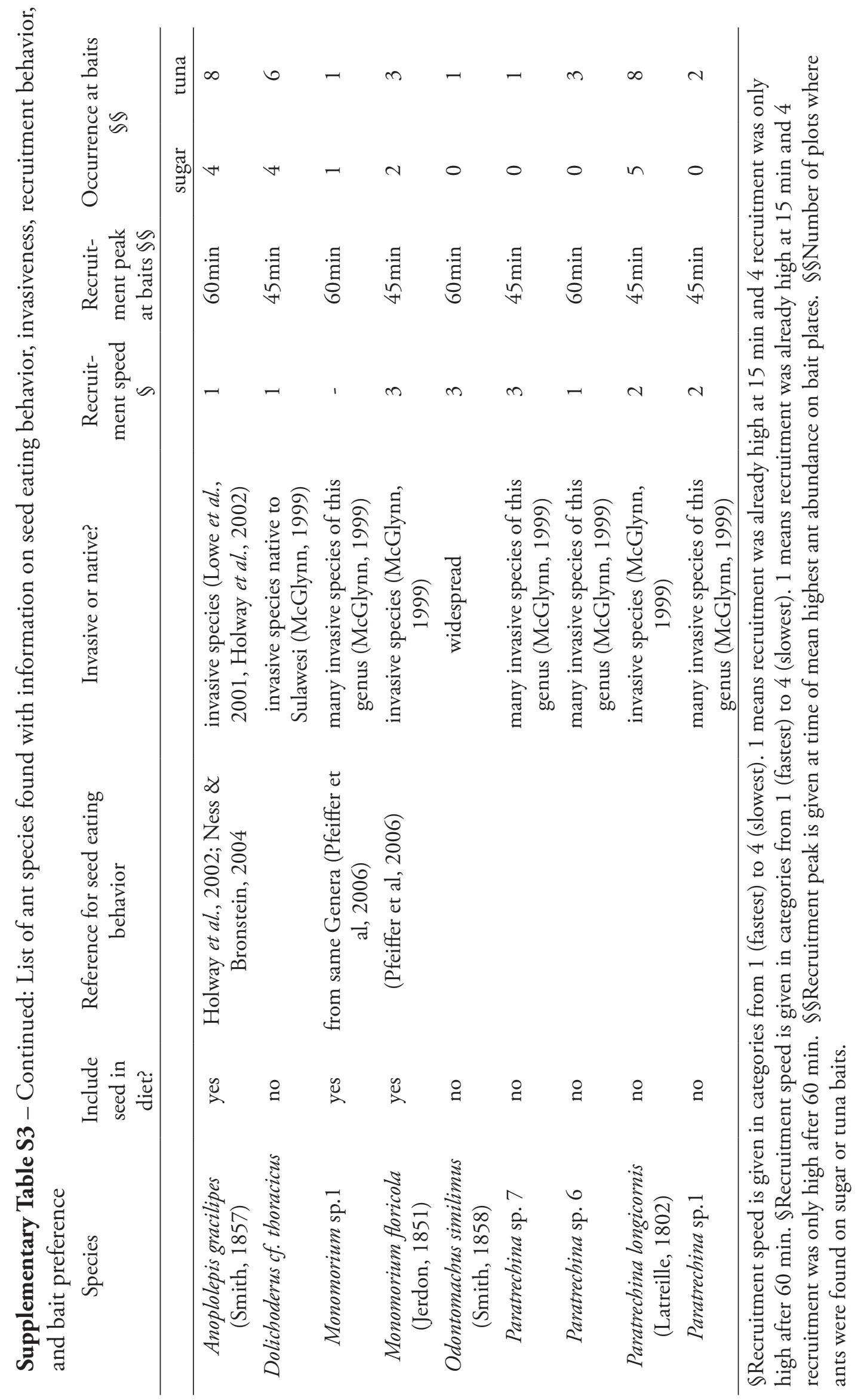




\section{REFERENCES (ONLY FOUND IN SUPPORTING INFORMATION)}

Culver, D.C. \& Beattie, A.J. (1978) Myrmecochory in Viola: Dynamics of seed-ant interactions in some West Virginia species. Journal of Ecology, 66, 53-72.

Holway, D.A. Lach, L., Suarez, A.V., Ysutsui, N.D. \& Case, T.J. (2002) The causes and consequences of ant invasions. Annual Review of Ecology, 33, 181-233.

Laman, T.G. (1996) The impact of seed harvesting ants (Pheidole sp. nov.) on Ficus establishment in the canopy. Biotropica, 28, 777-781.

Lowe, S., Browne, M. \& Boudjelas, S. (2001) 100 of the world's worst alien species. Aliens, 12, 1-14. McGlynn, T.P. (1999) The worldwide transfer of ants: geographical distribution and ecological invasions. Journal of Biogeography, 26, 535-48.

Pfeiffer, M., Nais, J., Sinun, W. \& Linsenmair, K.E. (2006) Worker size and seed size selection in 'seed'-collecting ant ensembles (Hymenoptera: Formicidae) in primary rain forests on Borneo. Journal of Tropical Ecology, 22, 685-693. 


\section{Chapter 5}

\section{SERVICES FROM PLANT-POLLINATOR INTERACTIONS IN THE NEOTROPICS}

Authors: Lucas Alejandro Garibaldi, Nathan Muchhala, Iris Motzke, Liliana Bravo-Monroy, Roland OlsCHeWsis and AleXandra-Maria KLeIN

Published as a book chapter in: (2011) Rapidel, B., De Clerck, FAJ, LeCoq, J.F., Beer, J. (eds.) Measuring and marketing ecosystem services from agriculture in the Neotropics. Earthscan publishing 


\section{INTRODUCTION}

The Neotropics, with its large expanses of rainforests, forests and woodland savannas, includes some of the most diverse places on Earth (Kricher, 1999; Myers et al, 2000). A large proportion of plant and animal species in Neotropical communities are unique, including several pollinator species, which provide essential services to human welfare. In general, pollinators are known to enhance the sexual reproduction of the majority of angiosperms (Kearns et al, 1998) and can be important for the production of many crop species (McGregor, 1976; Klein et al, 2007; Aizen et al, 2009a). There is a wide array of arthropod and vertebrate pollinator species in the Neotropics, although we know little about their natural history and contribution to pollination (Kevan and Imperatriz-Fonseca, 2002; Freitas et al, 2009).

This chapter reviews studies on pollination services in the Neotropics, with an emphasis on crop pollination. We briefly describe the main taxa involved in pollination, followed by a list of the main crops grown in the Neotropics and a description of how many they rely on biotic pollination. Because methods vary across studies, key methodologies to determine pollination services are summarized. Finally, we discuss management options to improve pollination services at the farm and landscape scale, and socio-economic drivers affecting pollination.

\section{Major Pollinator Taxa}

Pollination by animals plays a vital role for plant reproduction in the tropics, where it is estimated that more than 98 per cent of plants are animal pollinated (Bawa, 1990). However, in general, information on pollinator communities and the diversity of taxonomic guilds in the Neotropics is incomplete (Freitas et al, 2009). In this section we give examples of the major pollinator taxa in comparison to other regions.

Similar to the Old World, bees play a major role in pollination of Neotropical plants (Roubik, 1995). Around 5000 bee species are thought to occur in the Neotropics, including 391 eusocial stingless bee species (Meliponini), an important pollinating bee taxa (Slaa et al, 2006). The invasive Africanized honey bee, Apis mellifera scutellata Lepeletier, is widespread throughout the Neotropics. Although presumed to compete with native bees, evidence is still controversial (Roubik, 2009). Other important invertebrate pollinators are wasps (Hymenoptera), beetles (Coleoptera), moths and butterflies (Lepidoptera) and flies (Diptera).

Pollinators in the Neotropics seem to be as diverse as in other tropical areas (Roubik, 1995); but species composition and identity are highly distinct. For example, in South America, coffee 
(Coffea arabica L.) is predominately visited by the non-native Africanized honey bee, but also by a high diversity of stingless bees (Klein et al, 2008a). In contrast, coffee-visiting bee species in Southeast Asia include the native eastern honey bee (Apis cerana Fabricius), the giant honey bee ( $A$. dorsata Fabricius), the honey bee ( $A$. nigrocincta Smith), a close relative of the eastern honey bee, few stingless bee species, and a high diversity of solitary species (Klein et al, 2008a; Klein, 2009). Among vertebrate pollinators, birds, especially hummingbirds, followed by bats play the most important role for many wild flowers in the Neotropics. There are more than 300 hummingbird species confined to the Neotropics (Bawa, 1990). In agricultural systems, hummingbirds visit papaya (Carica papaya L.) and banana (Musa sp.) flowers (Free, 1993); but their role in crop pollination is not well documented. In other areas of the world, sunbirds (Palaeotropical and Pacific), sugarbirds (South Africa) and honeyeaters (Australasia) fill the ecological niche of hummingbirds in the Neotropics (Roubik, 1995; Ortega-Olivencia et al, 2005). Nectar-feeding bats are the second most widespread vertebrate pollinators in Neotropical rainforests, especially for many wild trees and epiphytes, but also for locally important crops (see Box 5.1).

\section{Biotic Pollination and Crop Production}

Biotic pollination is important for many crop species in the Neotropics. Altogether 44 crops and 4 commodities (method as in Klein et al, 2007) represent 99 per cent (98 and 1 per cent, respectively) of the total crop production in the Neotropics in 2007 (FAOSTAT, 2009). Of these, 29 (70 per cent) crops increase their seed or fruit production in the presence of animal pollination. In the following discussion we highlight the leading animal-pollinated crops in terms of cultivation area, and give further examples of highly pollinator-dependent crops.

The most important pollinator-dependent crops exotic to the Neotropics are coffee, coconut, citrus, mango, and soybean (Table 1; see Box 2 for details on coffee pollination; FAOSTAT, 2009). For example, soybean is the second most cultivated crop in the Neotropics. Primarily self-compatible, flower-visiting insects, such as honey bees, have been shown to increase soybean production, measured in kilograms per hectare (kg ha1), between 38 and 58 per cent for some varieties in Brazil (Chiari et al, 2005, 2008). Given the importance of this crop, more research on its pollination system across countries and varieties is urgently needed. The most important native Neotropical crops dependent totally or to certain degrees on insect pollination are cocoa, common bean, guava and cashew (see Table 1). Cocoa, for example, is generally highly selfincompatible and depends heavily on insect pollination, although a few self-compatible varieties exist (Falque et al, 1996). Tiny midges of the Ceratopogonidae and Cecidomyiidae families are predominantly 


\section{BOX I BAT POLLINATION IN THE NEOTROPICS}

Bat pollination is restricted to the tropics and subtropics; plant-visiting bat species do not occur in temperate regions (Koopman, 1981; Fleming and Muchhala, 2008). Bats adapted to a nectarivorous diet occur in two distantly related families: the Phyllostomidae in the Neotropics and teropodidae in the Palaeotropics. Of these, bat species of the sub-family Glossophaginae are the most morphologically and ecologically specialized; they possess elongated snouts, highly extensible tongues and the ability to hover in front of flowers like hummingbirds (Helversen, 1993; Winter and Helversen, 2003).

In the Neotropics, nectar bats are known to pollinate flowers from 360 species of plants in 159 genera from 44 families (Geiselman et al, 2002; Fleming et al, 2009). The majority of these are trees and epiphytes, including many conspicuous members of local ecosystems, such as canopy-emergent Bombacaeae trees in rainforests and large columnar cacti (e.g. saguaro, organ pipe cacti) in arid regions. Although numerically a relatively small proportion of total angiosperm diversity, bat-pollinated plant species cannot be serviced as effectively by other pollinator taxa because specialized floral adaptations are required to attract, fit and reward bats: hiropterophilous flowers typically are physically robust and well exposed beyond the foliage, have wide bell-shaped flowers or a 'brush' morphology, open nocturnally, and produce a strong odour and copious nectar (Helversen, 1993; Muchhala, 2007; Fleming et al, 2009). Although such adaptations require large investments in floral structures compared to other pollination systems, bats provide two important advantages as pollinators. First, they can carry large amounts of pollen in their hairs (Law and Lean, 1999; Muchhala and Thomson, 2010). Second, they can disperse this pollen over extremely long distances. For instance, paternity analyses reveal that pollen was transferred up to $18 \mathrm{~km}$ between individuals of the bat-pollinated kapok tree (Ceiba pentandra) (Dick et al, 2008). Such long-distance pollen dispersal improves gene flow, as evidenced in low genetic subdivision for bat-pollinated plant species (Roesel et al, 1996; Hamrick et al, 2002).

A number of bat-pollinated plants in the Neotropics provide economically important products. The kapok tree, which is pantropical and bat pollinated throughout its range (Elmqvist et al, 1992; Gribel et al, 1999; Nathan et al, 2005), produces silky fibres which are used in bedding and cushion materials. Many bat-pollinated cacti throughout the Americas produce edible fruits that are sold in local and international markets, often as jellies or jams (Anderson, 2001). Bat-pollinated dragon-fruit and other fruits of the cactus genus Hylocereus are now cultivated worldwide, both as food and as ornamental plants (Valiente-Banuet et al, 2007). Fruits of Stenocereus griseus (Haw.) Buxb. are harvested by indigenous communities, which also use the cacti for construction materials and as living fences (Nassar et al, 1997; Villalobos et al, 2007). The seed set of agaves, from which the well-known liquor tequila is derived, drops to less than 5 per cent in the absence of bat pollinators (Howell and Roth, 1981; Molina-Freaner and Eguiarte, 2003). Finally, many ornamental plants rely on bat pollination, such as Cobaea scandens Cav. and C. trianae Hemsl. (Polemoniaceae) (Vogel, 1969).
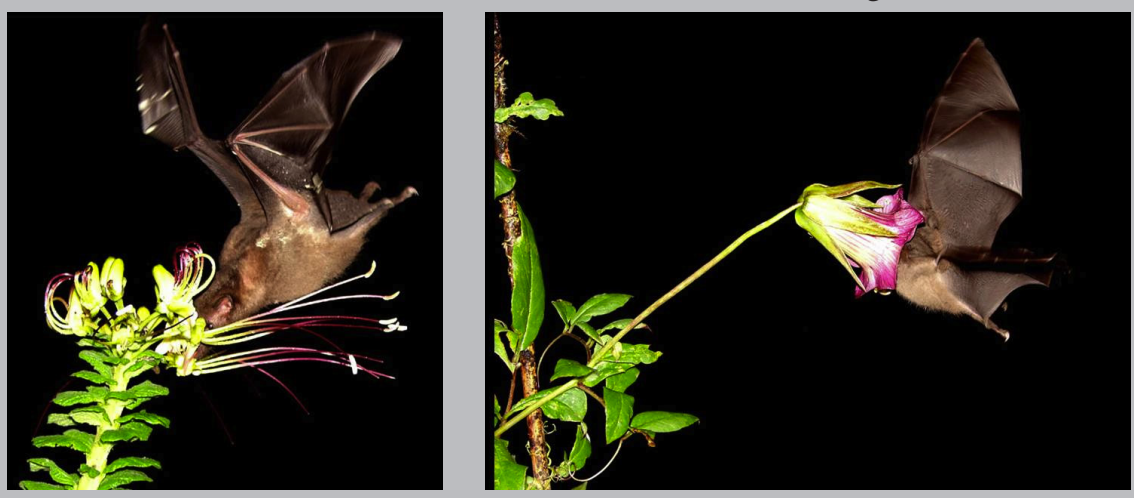

Figure 1 Anoura geoffroyi Gray, 1838 pollinating Cleome anamola Kunth (left) and the ornamental Cobaea trianae Hemsl. (right) Source: N. Muchhala 
responsible for pollination of the cocoa varieties that depend on insect pollination (Entwistle, 1972; Young, 1994). The cashew nut, native to Brazil, has both bisexual and male flowers on the same plant. This crop is frequently cultivated in the Neotropics (Roubik, 1995; Kevan and ImperatrizFonseca, 2002) and has two main pollinating species: the honey bee (Apis mellifera L.) and the native oil bee (Centris tarsata Smith) (Freitas and Paxton, 1998).

Many crops that depend on animal pollination are of high economic importance at a more local, country- or state-wide scale. For some of these crops, such as Brazil nut, melon, passion fruit, pumpkin, squash, vanilla and watermelon, animal pollination was found to be essential (Klein et $a l, 2007)$. Furthermore, a high number of crops depend partly (to certain degrees or under certain conditions) on animal pollination, such as agaves, annatto (or achiote), avocado, chayote, chilli pepper, common bean, dragon fruit, eggplant, guayule, jojoba, mesquite, papaya, peanut, pepper, pimento, rubber, quinine, sisal, soursop (or guanábana), star apple (or caimito), sunflower, tobacco and tomato (Roubik, 1995). Here we highlight two locally important native crops: passion fruit and avocado. Passion fruit (Passiflora edulis Sims) is cultivated throughout the Neotropics and has self-incompatible, large hermaphroditic flowers. It is mainly pollinated by large carpenter bees of the genus Xylocopa, as other frequent flower-visiting species are too small to touch the stigma during nectar and pollen collection (e.g. Benevides et al, 2009). Wind pollination is ineffective because pollen is heavy and sticky. Another important native crop is avocado (Persea americana Mill.), a variable and poorly understood species with respect to its pollination system. Avocado varieties vary between self-compatible to self-incompatible; but crosspollination through bees, bats, flies and wasps improves fruit production (Roubik, 1995). The flower is bisexual and opens twice; it functions as a female during the first opening, and functions usually as a male and releases pollen on the following day upon the second opening. Commercially grown avocado plantations are therefore planted with two complementary flowering groups to ensure the spatio-temporal availability of female and male openings for adequate pollination (Delaplane and Mayer, 2000).

In summary, 70 per cent of the leading crops in the Neotropics depend to some degree on animal pollination. This number is similar to that estimated for the global scale (74 per cent) (Klein et al, 2007), and also similar to tropical regions, in general (70 per cent: Roubik, 1995), to Argentina (74 per cent: Chacoff et al, 2010), Mexico (85 per cent: Ashworth et al, 2009) and the European Union (84 per cent: Williams, 1994). The latter two studies include many crops of minor importance in terms of production and total cultivated area, whereas the other calculations include major crops only. In general, however, few studies have evaluated pollination services in the Neotropics (Freitas et al, 2009); consequently, we know little about the pollinator relevance for 
Table 5.1 Pollinator dependence of the most cultivated crops in the Neotropics

\begin{tabular}{|c|c|c|c|c|}
\hline \multirow[t]{2}{*}{ Species } & \multirow[t]{2}{*}{ Crop } & \multirow{2}{*}{$\begin{array}{l}\text { Pollinator } \\
\text { depend- } \\
\text { ence* }\end{array}$} & \multicolumn{2}{|c|}{ Cultivated area } \\
\hline & & & (ha) & $(\%)$ \\
\hline Zea mays & Maize & none & $26,314,959$ & 24.6 \\
\hline Glycine max, G. soja & Soybean & modest & $24,124,332$ & 22.6 \\
\hline Saccharum officinarum & Sugar cane & none & $9,825,691$ & 9.2 \\
\hline $\begin{array}{l}\text { Phaseolus sp., P. vulgaris, } P \text {. lunatus, } \\
\text { P. angularis, P. aureus, P. mungo, P. } \\
\text { coccineus, P. calcaratus, P. aconitifolius, P. } \\
\text { acutifolius }\end{array}$ & $\begin{array}{l}\text { Bean dry like Kidney } \\
\text { bean, Haricot bean, Lima } \\
\text { bean, Azuki bean, Mungo } \\
\text { bean, String bean }\end{array}$ & little & $6,457,637$ & 6 \\
\hline $\begin{array}{l}\text { Coffea arabica, C. canephora (syn. Coffea } \\
\text { robusta), C. liberica }\end{array}$ & Coffee & modest & $5,667,250$ & 5.3 \\
\hline Oryza sp. (mainly O. sativa) & Rice, Paddy & none & $5,262,464$ & 4.9 \\
\hline $\begin{array}{l}\text { Triticum sp. (mainly T. aestivum, T. } \\
\text { durum, T. spelta) }\end{array}$ & Wheat & none & $3,236,071$ & 3 \\
\hline Sorghum guineense, S. vulgare, S. dura & Sorghum & none & $3,155,116$ & 3 \\
\hline $\begin{array}{l}\text { Manihot esculenta (syn. M. utilissima, } M \text {. } \\
\text { palmata) }\end{array}$ & Cassava & $\begin{array}{l}\text { only } \\
\text { breeding }\end{array}$ & $2,791,040$ & 2.6 \\
\hline $\begin{array}{l}\text { Musa sapientum, } M . \text { cavendishii, } M . \\
\text { nana, } M . \text { paradisiaca }\end{array}$ & Banana, Plantain & $\begin{array}{c}\text { only } \\
\text { breeding }\end{array}$ & $2,128,586$ & 2 \\
\hline $\begin{array}{l}\text { Gossypium hirsutum, G. barbadense, } G . \\
\text { arboreum, G. herbaceum }\end{array}$ & Cotton & modest & $1,735,189$ & 1.6 \\
\hline Theobroma cacao & Cocoa & essential & $1,490,461$ & 1.4 \\
\hline Citrus trifoliata & Orange & little & $1,442,261$ & 1.4 \\
\hline Anacardium occidentale & $\begin{array}{l}\text { Cashew nut, Cashew- } \\
\text { apple }\end{array}$ & high & $1,354,993$ & 1.3 \\
\hline Cocos nucifera & Coconut & modest & 672,713 & 0.6 \\
\hline $\begin{array}{l}\text { Hordeum disticum, } H \text {. hexasticum, } H \text {. } \\
\text { vulgare }\end{array}$ & Barley & none & 667,234 & 0.6 \\
\hline Elaeis guineensis & Oil palm & little & 611,211 & 0.6 \\
\hline Nicotiana tabacum & Tobacco & only sowing & 545,856 & 0.5 \\
\hline $\begin{array}{l}\text { Mangifera indica, Garcinia mangostana, } \\
\text { Psidium spp. }\end{array}$ & $\begin{array}{l}\text { Mango, Mangostan, } \\
\text { Guava }\end{array}$ & high & 458,435 & 0.4 \\
\hline
\end{tabular}

Notes: Harvested area data given for each crop are extracted from the FAO dataset for the year 2007

(FAOSTAT, 2009). Argentina, Chile and Uruguay were excluded; but examples from these countries are discussed in the chapter when appropriate (e.g. Chacoff and Aizen, 2006). Listed crops accounted for 93 per cent of the total cultivated land in the Neotropics in 2007. Pollinator dependence data obtained from Klein et al (2007). Pollinator dependence: none = yield not dependent on animal pollination; little $=$ yield reduction $>0$ but $<10$ per cent without pollinators; modest $=10-40$ per cent reduction; high $=$ 40-90 per cent reduction; essential $=$ reduction $>90$ per cent; only breeding = pollinators increase seed production for breeding (in commercial farming, the plants are propagated from vegetative organs and the vegetative parts are harvested); only sowing = pollinators increase seed production to produce the vegetative parts that are harvested. 
many widely cultivated crops or about the variability of pollinator requirements among varieties.

\section{Determination of Crop Pollination Services}

Pollination can be important for agricultural and non-domesticated plants; however, the actual impact of these services is difficult to estimate. To better understand pollination services, it is important not only to measure the interaction between a pollinator and a certain crop or plant species, but to identify biophysical and socio-economic drivers in an interdisciplinary approach (see Figure 3; Bayon and Jenkins, 2010).

Pollinators can provide direct benefits by increasing the amount and interannual stability of crop yield quantity (kg of product ha1) and quality (e.g. fruit size, shape, weight), and indirect effects such as maintaining plant and animal biodiversity and their associated benefits for human welfare. These services can be promoted by either pollinator abundance or diversity (Hoehn $e t$ al, 2008; Klein, 2009; Klein et al, 2009; Vergara and Badano, 2009). We would like to note that some flower visitations may be a disservice to crops, as has been demonstrated for flowers in the wild. This can occur in the form of nectar or pollen robbery where a 'pollinator species' takes nectar or pollen without pollinating the plant (Irwin et al, 2001; Thomson, 2003; Hargreaves et al, 2009). However, we have found no studies showing that the exclusion of flower visitors has positive effects on crop pollination. The exclusion of wild visitors commonly reduces or does not significantly affect pollination services (Klein et al, 2007).

Many studies have measured pollinator abundance, pollinator richness/diversity, flower visitation rates, pollen deposition, pollen tube growth, and/or seed/fruit set (Klein et al, 2007). Fewer studies, however, have determined direct production variables (e.g. yield quality or quantity) at a farm (plot) scale. These calculations are also relevant at the socio-economic scale where decisions on land use are made (see the section on 'Socio-economic drivers affecting pollination services') (Ghazoul, 2007; Klein et al, 2008b; Veddeler et al, 2008). When estimating pollination services, the following processes and methods should be considered:

- Biotic pollination can be evaluated by comparing crop yield of pollinator exclusion (only self abiotic pollination) and free pollination (self abiotic biotic pollination) treatments (e.g. Klein, 2009; Vergara and Badano, 2009).

- Abiotic pollination can be estimated by comparing an abiotic plus biotic pollination exclosure treatment with a pollinator exclosure treatment.

- Self-pollination: by preventing any outcross pollen from reaching the flower (abiotic plus 


\section{BOX 2 POLLINATORS AND COFFEE PRODUCTION IN THE NEOTROPICS}

Coffee is one of the most important cash crops in the Neotropics. It is traded at the global market and accounts for nearly 5.7 million hectares of land in 2007 (see Table 1). For many years, coffee has been the second leading export product of developing countries (ICO, 2009), providing income and employment for millions of people.

Since the 1950s, many studies have shown that pollinators promote coffee yield (production per plant or hectare) by increasing fruit set and/or berry weight (see reviews by Free, 1993; Klein et al, 2007). Pollinators have also been shown to reduce the frequency of 'peaberries' - that is, small misshapen seeds (Free, 1993; Ricketts et al, 2004). The magnitude of the positive effects on yield can vary greatly, between 10 and 40 per cent among studies using different methodologies and environmental conditions (see Table 1) (Klein $e t ~ a l, 2007)$. Studies finding positive effects on coffee yield include those performed at the plant scale (therefore not biased by resource allocation patterns within the plant) (Free, 1993) and those performed for more than one year (Ricketts et al, 2004). Positive effects of pollinators on both seed number and weight have also been found simultaneously, without the confounding effects of seed number versus size compensation (Ricketts et al, 2004). In most studies, the honey bee was found to be the most frequent visitor to coffee flowers, followed by stingless bees, and some semi-social and solitary bee species (see the previous section on 'Major pollinator taxa').

Research addressing the effects of habitat and landscape scale on coffee pollination began only during the last decade. They include studies in Panama (Roubik, 2002a), Venezuela (Manrique and Thimann, 2002), Costa Rica (Ricketts, 2004), Brazil (De Marco and Coelho, 2004), Ecuador (Veddeler et al, 2006) and Mexico (Vergara and Badano, 2009). These studies considered variables such as distance between coffee plants and adjacent forests or cultivation variables such as shade versus sun coffee. All studies found more bee species, higher visitation frequency, higher fruit set and/or higher berry weight on coffee plants bordering forests.

Other studies highlighted the monetary value of coffee pollination services, such as Roubik (2002b) in Panama; Ricketts et al (2004) in Costa Rica, and Benitez et al (2006), Olschewski et al (2006) and Veddeler et al (2008) in Ecuador. For example, the extrapolation of data gained from pollination experiments in Costa Rica estimated that the value of pollination services for two forest fragments (46ha and $111 \mathrm{ha}$ ) in a single farm (480ha) was US\$60,000 annually (Ricketts et al, 2004). Veddeler et al (2008) calculated that a fourfold increase in bee density would translate to an 800 per cent increase in net revenues for coffee farms in Ecuador. Certainly, wild habitats are providing important pollination services for this crop.
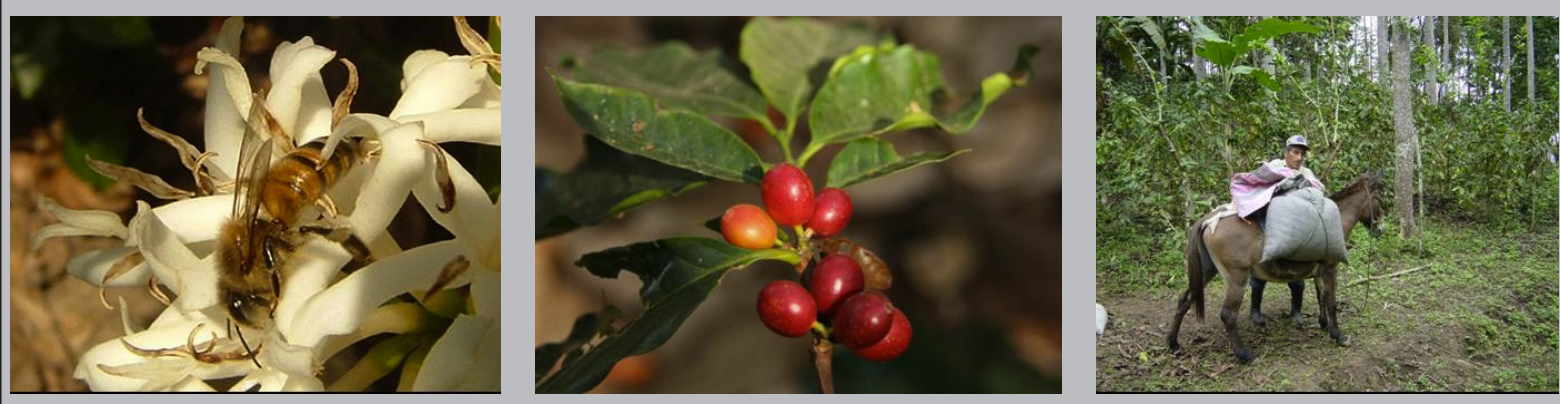

Figure 5.2 Coffee production in Manabi, coastal Ecuador: From left toright are the Africanized honey bee, Apis mellifera scutellata (Lepeletier), foraging on coffee flowers; ripe coffee berries at harvest; traditional harvest with mules Source: D. Veddeler (bee and berries); A. M. Klein (traditional harvest) 
biotic pollination exclosure), the degree of self-pollination can be evaluated.

- Pollen limitation: pollen addition (hand pollination) and control treatments are useful to understand the degree of pollen limitation (see review by Wesselingh, 2007).

- Self-incompatibility: the addition of pollen from the same individual versus addition from other individuals (out-crossing) can be used to quantify the degree of self-incompatibility.

Other considerations when studying the above processes are:

- Natural history and field censuses: knowledge on pollinators' natural history and censuses of flower visitation helps to understand plant-pollinator interactions and to identify key pollinator species and their requirements (e.g. for habitat) (Kevan and ImperatrizFonseca, 2002).

- Number of replicates: the estimation of the number of (independent) replicates needed given an expected variability and a required precision is critical for obtaining useful information from experiments.

- Relevant production variables: from an applied perspective, it is important to measure the quantity and quality of yield, and the spatial and temporal stability in both variables (Ghazoul, 2007; Klein et al, 2008b).

- Spatial and temporal scale: when possible, treatments should be applied to plots, which are usually the scale of interest when measuring pollination services (or sometimes entire plants). Special attention should be given to perennial plants, in which plant resource allocation strategies can involve years (e.g. high allocation to vegetative growth during one year, but higher allocation for reproduction in the following year). Therefore, experiments should ideally be followed during the whole plant productive cycle and over consecutive years.

- Variability in pollen and pollinator limitation: the impact of pollen limitation on crop production may vary greatly depending on other environmental factors such as resource availability (water, nutrients and radiation), abiotic conditions (e.g. frosts) and pests (Bos et al, 2007; Ghazoul, 2007; Klein et al, 2008b). Pollen limitation may also vary with crop variety, and the magnitude of pollinators' exclusion effects may greatly depend on the resident pollinator community. Studies over multiple seasons and years are useful to account for periodic weather perturbations and temporal variation in pollinator communities (Klein, 2009). 
- Socio-economic assessments: it is important to understand the value of pollination services for different aspects of a society (e.g. cultural and economic; see the section on 'Socioeconomic drivers affecting pollination services').

Depending on the focus, other measurements and treatments can be included. Examples are the exclusion of vertebrate but not invertebrate pollinators to understand their interactions and relative contribution to pollination, or the study of niche complementarity among invertebrate pollinator species (Hoehn et al, 2008). Here, we emphasize methods to quantify the degree of overall pollination and pollinator limitation on crop production at a farm (plot) scale.

\section{Management to Improve Pollination Services at the Landscape and Farm Scale}

In the previous sections we described how lack of animal pollination can limit the yield of certain crops. There is also evidence that wild pollinator species are decreasing locally (Ricketts et al, 2008) and regionally (Biesmeijer et al, 2006; Brown and Paxton, 2009; Freitas et al, 2009) due to landuse changes and the application of agrochemicals, among other factors. A recent review suggested that the effects of habitat loss on flower visitation rates should be higher in the tropics compared to temperate zones (Ricketts et al, 2008). Therefore, it is increasingly important to understand the drivers affecting pollinator abundance and diversity for adequate pollinator management and conservation. Management for wild pollinators usually implies decisions at the landscape and farm level to provide floral resources, breeding areas and nesting habitats within the flying range of pollinators (Kevan and Imperatriz- Fonseca, 2002; Kremen, 2008).

\section{LANDSCAPE AND HABITAT MANAGEMENT}

Pollination services can vary widely depending on the quantity, quality and spatial arrangements of habitat types in the landscape. Because flying has energy costs and many pollinators have fixed nest sites, pollinators prefer flower visits close to their habitat. Recently, Ricketts et al (2008) reviewed 23 studies representing 16 crops on 5 continents to evaluate the effects of distance from natural or semi-natural habitats on pollination services. They found that visitation rates by wild pollinators and pollinator richness decreased exponentially with distance from natural habitat, reaching half of its maximum at $0.6 \mathrm{~km}$ and $1.5 \mathrm{~km}$, respectively. However, they found no evidence of effects on fruit and seed set, although such effects were only measured by half of the studies and most of them did not measure the size, quality or stability of yield (see the previous section on 'Determination of crop 
pollination services'). Among the reviewed studies, only four were performed in the Neotropics. Decreases in native visitation rates with distance from natural habitat was observed for highland coffee in Costa Rica (Ricketts, 2004; Ricketts et al, 2004) and grapefruit in northwestern Argentina (Chacoff and Aizen, 2006); but no effect was found for passion fruit in eastern Brazil (Ricketts et al, 2008) or for oil palm in southern Costa Rica (Mayfield, 2005; Ricketts et al, 2008). Overall, these studies suggest that the conservation of natural habitats close to agriculture can be important to enhance wild pollinator diversity and flowervisiting frequency, although the effects of habitat conservation on pollination services needs to be further evaluated. Moreover, most of these studies use either distance or proportional area of natural habitat as the landscape variable; future studies should also consider the effects of the spatial arrangement of habitat patches in terms of distance, number, size and quality (Olschewski et al, 2010).

The magnitude of positive effects from natural habitat proximity can vary greatly among pollinator species. It is proposed that species with high dispersal abilities will be less affected by habitat degradation at relatively short distances. For example, a review concerning tropical crops found that small cavity-nesting bees and generalist beetles required natural forest near their foraging areas, whereas insects with large body sizes explored larger areas and were therefore less sensitive to isolation from forest (Klein et al, 2008a). Overall, taking into account the biology of species and considering different spatial scales will improve our understanding of the effects that land-use change has on habitat quality for pollinator species (Steffan-Dewenter et al, 2002; Tscharntke et al, 2005).

Habitat quality involves the abundance of appropriate floral resources, nesting places and the possibility to escape from natural enemies and diseases. Managing habitat quality requires detailed knowledge of the species' natural history. When the habitat is highly degraded, active management may be required (e.g. sowing or transplanting native species as well as constructing suitable habitat).

A matrix of agricultural and natural patches can be beneficial to pollinators because of a higher diversity of resources (Tscharntke et al, 2005; Winfree et al, 2007, 2008). Enhanced diversity and abundance of pollinators in these complex landscapes may also provide services to a wider spectrum of crops (Kremen, 2008). Pollination services should be greater when agricultural field sizes are smaller because of greater habitat complexity within the flying range of pollinators. Unfortunately, there is a trend towards increasing field size and homogenization of agricultural landscapes in the Neotropics and many other regions (Tscharntke et al, 2005; Aizen et al, 2009b). These landscape variables also interact with decisions at the farm scale because crop management influences the quality of habitat for wild pollinators. 


\section{FARM AND POLLINATION MANAGEMENT}

There are several agricultural practices that can improve the visitation of wild pollinators to flowers, such as small-scale farming, polycultures, sowing of diverse flower resources in edge habitats (e.g. field boundaries) and reduced use of agrochemicals (Tscharntke et al, 2005, Brosi et al, 2008). In general, farming practices that increase habitat diversity (and, thus, pollinator diversity) should promote pollination services because of:

- species complementarity, when species use different resource parts or promote positive intra-guild interactions;

- sampling effects, when higher biodiversity increases the probability of including species that provide important services; and

- redundancy, when different species provide a similar pollination service in highly diverse habitats, which is important for reorganization after disturbance (insurance hypothesis) (see reviews by Tscharntke et al, 2005; Klein et al, 2009).

For example, rustic shade coffee managed under native forest in Veracruz (Mexico) showed higher pollinator diversity and fruit production than less diverse sun coffee systems where native forest was removed (Vergara and Badano, 2009).

Although several thousand species contribute to pollination, only a few are managed. Examples include stingless bees as pollinators for tomatoes in Mexico (Cauich et al, 2004) and Brazil (Del Sarto et al, 2005) greenhouse production, and also for other crops such as cucumber and sweet pepper in the Neotropics (see reviews by Cortopassi-Laurino et al, 2006; Slaa et al, 2006). However, most managed pollinators are honey bees (Kevan and Imperatriz- Fonseca, 2002). This reliance on a single pollinator species seriously threatens the stability of pollination services. Indeed, higher incidence of pests and diseases in the US decreased the number of managed honey bee colonies during the past years, and raised several problems for the pollination of important crops such as almond in California (Oldroyd, 2007). In the Neotropics, for example, there has been an increase in the reproductive ability of the mite Varroa destructor Anderson \& Truemann in the widely spread Africanized honey bee in southern Brazil (Carneiro et al, 2007). Furthermore, Apis mellifera L. is not the most efficient pollinator species for many crops (Freitas and Paxton, 1998; Greenleaf and Kremen, 2006). The temporal and spatial stability, as well as the rate of pollination services, can be improved by pollinator diversity (Greenleaf and Kremen, 2006; Klein, 2009; Klein et al, 2009).

Hand pollination is a difficult and laborious task that is currently performed only in expensive crops under intensive farming. This is the case for vanilla (Vanilla planifolia L.), an orchid native to 
Mexico and a highly pollinator- dependent crop species (Davis, 1983; Klein et al, 2007). In general, species with large flowers are easier to hand pollinate than species with small flowers. However, pollinators provide not only quantity of pollen, but also pollen quality (e.g. cross-pollination) and special techniques of pollen transfer (e.g. vibration). Performing such tasks by hand at the proper production scale is both challenging and expensive.

For many pollinator-dependent crops, there are some varieties that are non-dependent so that farmers have the choice to choose varieties that do not need pollinators. However, despite genetic engineering and crop breeding advances, many of the most important crop species depend on pollinating animals (see Table 1) (Klein et al, 2007).

\section{Socio-Economic Drivers Affecting Pollination Services}

Land-use decisions affecting pollination services are made at the household or farm scale in response to several environmental and socio-economic variables (see Figure 3) (Lambin et al, 2001). Crop production often depends on environmental drivers such as resource availability (e.g. water and radiation), abiotic conditions (e.g. temperature), incidence of pests and weeds, and pollination services (see Figure 3). Several socio-economic drivers interact with environmental variables to affect land-use decisions, such as markets, demography, technology, institutional settings and public policy. This section briefly describes the socio-economic drivers of farmers' decision-making that influence the landscape and habitat management of pollination services (see previous section).

Relevant socio-economic drivers of land-use decisions are established markets, and the participation in trade. Besides income generation, participating in trade might have further advantages, such as access to credit, information, technology and urban centres. However, the importance of markets for small-scale producers depends on the type of land use considered, such as production of food (subsistence) versus cash crops (Cronon, 1985; Burgi and Turner, 2002; Black et al, 2003; Guhl, 2008). Supply and demand determine the market price and, thus, the profitability of crop species. The structure and functioning of markets allows us to understand how small-scale agricultural systems are connected to trade and market relationships. In general, pollinator-dependent crops achieve higher market prices (Gallai et al, 2009), thereby generating incentives to increase their production. However, a lack of pollinators might hinder the producers from doing so, and might force them to switch to less attractive non-pollination dependent crops.

Small-scale farmers' land-use decisions are often based on a comparison of net revenues. They depend on the product price, the quantity of the harvest and on the production costs. A case study in 
coastal Ecuador included these factors and assessed the impact of forest areas providing bee habitats and thereby enhancing pollination services for adjacent coffee production. It was shown that the impact on net revenues was significantly positive (Olschewski et al, 2006). However, alternative crops such as maize were more attractive from an economic point of view in that landowners had a strong incentive to convert forests into cropland. As a consequence, payments for single ecosystem services such as pollination are hardly sufficient to preserve bee habitats. Payment schemes should comprise further forest ecosystem services (e.g. carbon sequestration, soil and water conservation) in order to be effective.

Demography and other social criteria, such as gender, age and education, are common elements that influence land-use strategies (Mazvimavi and Twomlow, 2009). Institutional aspects such as landownership and tenure rights might be another powerful determinant (Wunder, 2000; Burgi and Turner, 2002; Black et al, 2003) - for example, owners are supposed to make different production decisions than tenants. Furthermore, it is important to consider underlying cultural beliefs and social perceptions of different land-use types (Nyerges and Green, 2000). Taking these into account might help to explain why families in the Neotropics often maintain small-scale farming despite modest income-generating opportunities.

Further important drivers of land-use change are agricultural knowledge and available technology (Angelsen and Kaimowitz, 1999; Burgi and Turner, 2002; Anastasopoulou et al, 2009). Among others, the inclusion of machinery may promote the cultivation of larger and more homogeneous fields. Additionally, the development of new crop varieties may affect pollination requirements and pollination service rewards. Little knowledge or experience on cultivation practices for a particular crop may also induce farmers to avoid the cultivation of that specific crop. Finally, public policies are crucial because they can establish incentives and recommendations regarding the adoption of specific land-use systems through their influence on several other drivers mentioned above (Burgi and Turner, 2002; Di Falco and Perrings, 2006; Anastasopoulou et al, 2009).

The variety of socio-economic drivers and their interactions show that simple explanations hardly provide adequate understanding of land-use change (Lambin et al, 2001). Various human and environmental conditions lead to specific land-use decisions, and policy recommendations aiming at habitat or landscape conservation should take these interactions into account. 


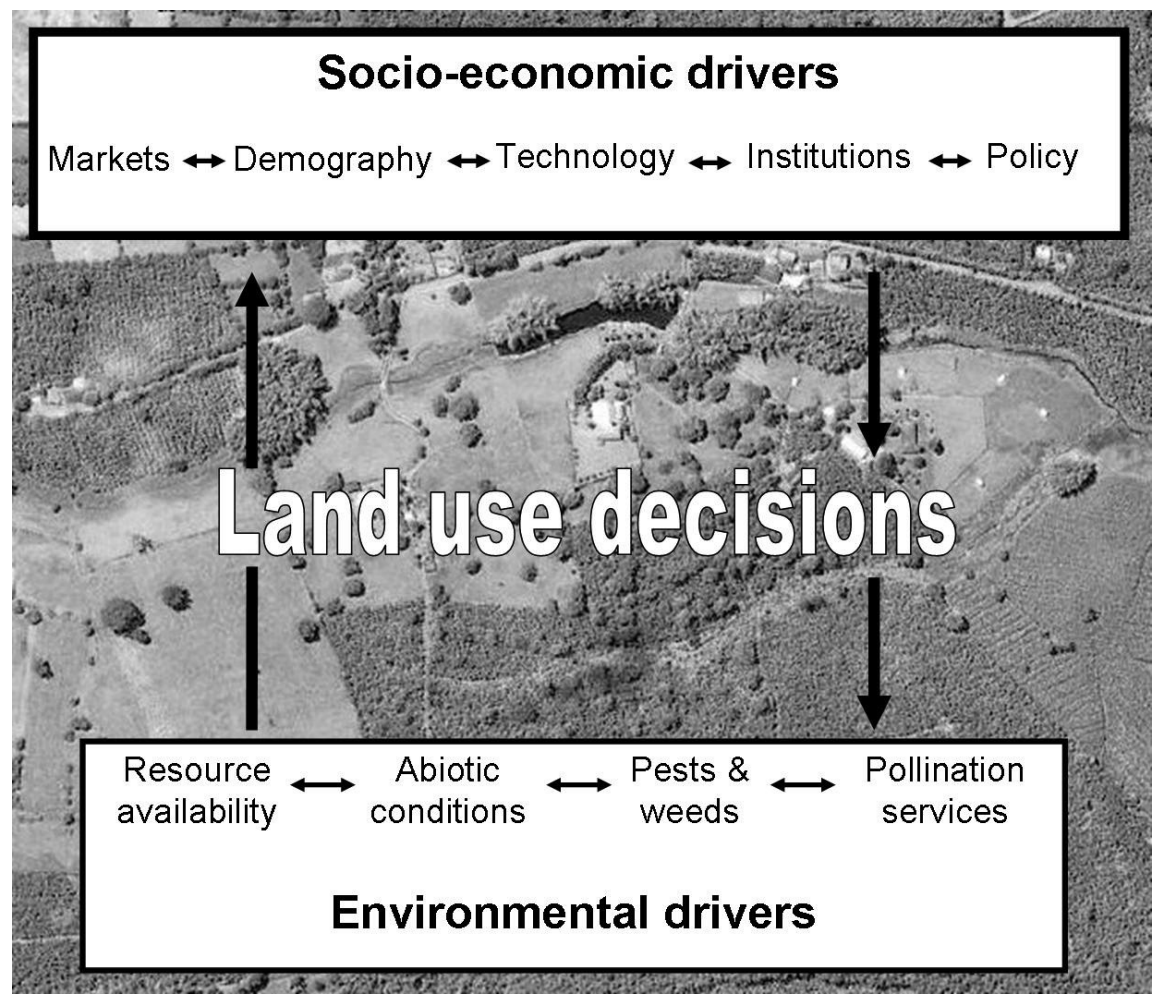

Figure 3 Socio-economic and environmental drivers of land-use decisions and crop productivity Note: See explanations in the chapter. Source: chapter authors

\section{ConCLuSIONS}

We have shown that pollination services by wild pollinators are important for crop production in the Neotropics. However, our knowledge of the services that pollinators provide in terms of the amount, quality and stability of crop production is still deficient. It is also critical to understand how multiple socioeconomic drivers influence the selection of particular management systems and, thus, the environmental services delivered. Land-use decisions based on short-term revenue calculations can lead to unsustainable results. Despite the high potential of social benefits, sometimes the net revenues obtained from pollination services through the preservation of a natural habitat are lower than other uses of that land, such as deforestation and crop cultivation. Future evaluations should also consider ecosystem services other than pollination and their interactions to reliably estimate the ecological and social benefits of conserving natural habitats. It is important to determine the value (monetary and non-monetary) of these services in order to raise awareness of ecosystem services when making decisions on particular land-use systems, and to support the design of appropriate conservation policies that benefit farmers and their environment. 


\section{ACKNOWLEDGEMENTS}

We are grateful to C. L. Morales and J. Juhrbandt for their thoughtful comments on a previous draft of this chapter. Lucas A. Garibaldi and Iris Motzke were supported by the German Academic Exchange Programme (DAAD). Liliana Bravo-Monroy was supported by the University of Reading (Alumni Study Travel Fund) and the Society for Experimental Biology (the Company of Biologists Travel Fund).

\section{REFERENCES}

Aizen, M. A., Garibaldi, L. A., Cunningham, S. A. and Klein, A. M. (2009a) 'How much does agriculture depend on pollinators? Lessons from long-term trends in crop production', Annals of Botany, vol 103, pp1579-1588

Aizen, M. A., Garibaldi, L. A. and Dondo, M. (2009b) 'Expansión de la soja y diversidad de la agricultura argentina', Ecología Austral, vol 19, pp45-54

Anastasopoulou, S., Chobotova, V., Dawson, T., Kluvankova-Oravska, T. and Rounsevell, M. (2009) 'Identifying and assessing socio-economic and environmental drivers that affect ecosystems and their services', The Rubicode Project, Rationalising Biodiversity Conservation in Dynamic Ecosystems, European Commission, Sixth Framework Programme

Anderson, E. F. (2001) The Cactus Family, Timber Press, Portland, OR

Angelsen, A. and Kaimowitz, D. (1999) 'Rethinking the causes of deforestation: Lessons from economic models', The World Bank Research Observer, vol 14, no 1 (February), pp73-98

Ashworth, L., Quesada, M., Casas, A., Aguilar, R. and Oyama, K. (2009) 'Pollinatordependent food production in Mexico', Biological Conservation, vol 1424, pp1050-1057. Bayon, R. and Jenkins, M. (2010) 'The business of biodiversity', Nature, vol 466, pp184-185

Bawa, K. S. (1990) 'Plant-pollinator interactions in tropical rain forests', Annual Review of Ecology, Evolution, and Systematics, vol 21, pp399-422

Benevides, C. R., Gaglianone, M. C. and Hoffmann, M. (2009) 'Yellow passion fruit (Passiflora edulis f. flavicarpa Deg. Passifloraceae) floral visitors in cultivated areas

within different distances from forest remnants in north Río de Janeiro', Revista

Brasileira de Entomologia, vol 53, pp415-421

Benitez, P. C., Kuosmanen, T., Olschewski, R. and Van Kooten, G. C. (2006) 'Conservation payments under risk: A stochastic dominance approach', American Journal of Agricultural 
Economics, vol 88, pp1-15

Biesmeijer, J. C., Roberts, S. P. M., Reemer, M., Ohlemuller, R., Edwards, M., Peeters,

T., Schaffers, A. P., Potts, S. G., Kleukers, R., Thomas, C. D., Settele, J. and Kunin, W. E. (2006)

'Parallel declines in pollinators and insect-pollinated plants in Britain and the Netherlands', Science, vol 313, pp351-354

Black, A. E., Morgan, P. and Hessburg, P. F. (2003) 'Social and biophysical correlates of change in forest landscapes of the interior Columbia Basin, USA', Ecological Applications, vol 13, pp51-67

Bos, M. M., Veddeler, D., Bogdanski, A., Klein, A. M., Tscharntke, T., Steffan-Dewenter, I. and Tylianakis, J. M. (2007) 'Caveates to quantifying ecosystem services: Fruit abortion blurs benefits from crop pollination', Ecological Applications, vol 17, pp1841-1849

Brosi, B. J., Armsworth, P. R. and Daily, G. C. (2008) 'Optimal design of agricultural landscapes for pollination services', Conservation Letters, vol 1, pp26-27

Brown, M. J. F. and Paxton, R. J. (2009) 'The conservation of bees: A global perspective', Apidologie, vol 40, pp410-416

Burgi, M. and Turner, M. G. (2002) 'Factors and processes shaping land cover and land cover changes along the Wisconsin River', Ecosystems, vol 5, pp184-201

Carneiro, F. E., Torres, R. R., Strapazzon, R., Ramírez, S. A., Guerra Jr, J. C. V., Koling, D. F. and Moretto, G. (2007) 'Changes in the reproductive ability of the mite Varroa destructor (Anderson e Trueman) in Africanized honey bees (Apis mellifera L.) (Hymenoptera: Apidae) colonies in southern Brazil', Neotropical Entomology, vol 36, pp949-952

Cauich, O., Quezada-Euán, J. J. G., Macias-Macias, J. O., Reyes-Oregel, V., Medina-Peralta, S. and Parra-Tabla, V. (2004) 'Behavior and pollination efficiency of Nannotrigona perilampoides (Hymenoptera: Meliponini) on greenhouse tomatoes (Lycopersicon esculentum) in subtropical Mexico', Journal of Economic Entomology, vol 97, pp475-481

Chacoff, N. P. and Aizen, M. A. (2006) 'Edge effects on flower-visiting insects in grapefruit plantations bordering premontane subtropical forest', Journal of Applied Ecology, vol 43, pp18-27

Chacoff, N. P., Morales, C. L., Garibaldi, L. A., Ashworth, L. and Aizen, M. A. (2010) 'Pollinator dependence of Argentinean agriculture: Current status and temporal analysis', The Americas Journal of Plant Science and Biotechnology, vol 3 (Special Issue 1), pp106-116

Chiari, W. C., Arnaut de Toledo, V. D. A., Ruvolo-Takasusuki, M. C. C., De Oliveira, A. J. B., Sakaguti, E. S., Attencia, V. M., Costa, F. M. and Mitsui, M. H. (2005) 'Pollination of 
soybean (Glycine max L. Merril) by honey bees (Apis mellifera L.)', Brazilian Archives of Biology and Technology, vol 48, pp31-36

Chiari, W. C., Arnaut de Toledo, V. D. A., Hoffmann-Campo, C. B., Ruvolo- Takasusuki, M. C. C., de Oliveira Arnaut de Toledo, T. C. S. and Lopes, T. D. S. (2008) 'Pollination by Apis mellifera in transgenic soy (Glycine max (L.) Merrill) Roundup Ready (TM) cv. BRS 245 RR and conventional cv. BRS 133', Acta Scientiarum-Agronomy, vol 30, pp267-271

Cortopassi-Laurino, M., Imperatriz-Fonseca, V. L., Roubik, D. W., Dollin, A., Heard, T., Aguilar, I., Venturieri, G. C., Eardley, C. and Nogueira-Neto, P. (2006) 'Global meliponiculture: Challenges and opportunities', Apidologie, vol 37, pp275-292

Cronon, W. (1985) Changes in the Land: Indians, Colonists, and the Ecology of New England, Hill and Wang, New York, NY

Davis, E. W. (1983) 'Experiences with growing vanilla (Vanilla planifolia)', Acta Horticulturae, vol 132, pp23-29

De Marco, J. and Coelho, F. (2004) 'Services performed by the ecosystem: Forest remnants influence agricultural cultures', Biodiversity and Conservation, vol 13, pp1245-1255

Del Sarto, M. C. L., Peruquetti, R. C. and Campos, L. A. O. (2005) 'Evaluation of the Neotropical stingless bee Melipona quadrifasciata (Hymenoptera: Apidae) as pollinator of greenhouse tomatoes', Journal of Economic Entomology, vol 98, pp260-266

Delaplane, K. S. and Mayer, D. F. (2000) Crop Pollination by Bees, CABI Publishing, New York, NY

Di Falco, S. and Perrings, C. (2006) '16 cooperatives, wheat diversity and the crop productivity in southern Italy', in M.A. Smale (eds) Valuing Crop Biodiversity on Farm Genetic Resources and Economic Change, CABI Publishing, Oxfordshire, UK

Dick, C. W., Hardy, O. J., Jones, F. A. and Petit, R. J. (2008) 'Spatial scales of pollen and seedmediated gene flow in tropical rain forest trees', Tropical Plant Biology, vol 1, pp20-33

Elmqvist, T., Cox, P. A., Rainey, W. E. and Pierson, E. D. (1992) 'Restricted pollination on oceanic islands - pollination of Ceiba pentandra by flying foxes in Samoa', Biotropica, vol 24, pp15-23

Entwistle, P. F. (1972) Pests of Cocoa, Longman, London

Falque, M., Lesdalons, C. and Eskes, A. B. (1996) 'Comparison of two cacao (Theobroma cacao L.) clones for the effect of pollination intensity on fruit set and seed content', Sexual Plant Reproduction, vol 9, pp221-227

FAOSTAT (2009) ProdSTAT Database, Food and Agriculture Organization of the United Nations, 
http://faostat.fao.org/site/567/default.aspx\#ancor, last accessed October 2009

Fleming, T. H. and Muchhala, N. (2008) 'Nectar-feeding bird and bat niches in two worlds: Pantropical comparisons of vertebrate pollination systems', Journal of Biogeography, vol 35, pp764-780

Fleming, T. H., Geiselman, C. and Kress, W. J. (2009) 'The evolution of bat pollination: A phylogenetic perspective', Annals of Botany, vol 104, pp1017-1043

Free, J. B. (1993) Insect Pollination of Crops, Academic Press, London

Freitas, B. M. and Paxton, R. J. (1998) 'A comparison of two pollinators: The introduced honey bee Apis mellifera and an indigenous bee Centris tarsata on cashew Anacardium occidentale in its native range of NE Brazil', Journal of Applied Ecology, vol 35, pp109-121

Freitas, B. M., Imperatriz-Fonseca, V. L., Medina, L. M., Kleinert, A. D. M. P., Galetto, L., NatesParra, G. and Quezada-Euán, J. J. G. (2009) 'Diversity, threats and conservation of native bees in the Neotropics', Apidologie, vol 40, pp332-346

Gallai, N., Salles, J.-M., Settele, J. and Vaussuère, B. E. (2009) 'Economic valuation of the vulnerability of world agriculture confronted with pollinator decline', Ecological Economics, vol 68, pp810-821

Geiselman, C. K., Mori, S. A. and Blanchard, F. (2002) Database of Neotropical Bat/Plant Interactions, www.nybg.org/botany/tlobova/mori/batsplants/database/ dbase_frameset.htm

Ghazoul, J. (2007) 'Recognising the complexities of ecosystem management and the ecosystem service concept', GAIA, vol 16, pp215-221

Greenleaf, S. S. and Kremen, C. (2006) 'Wild bees enhance honey bees' pollination of hybrid sunflower', Proceedings of the National Academy of Sciences, vol 103, pp13890-13895

Gribel, R., Gibbs, P. E. and Queiroz, A. L. (1999) 'Flowering phenology and pollination biology of Ceiba pentandra (Bombaceae) in Central Amazonia', Journal of Tropical Ecology, vol 15, pp247-263

Guhl, A. (2008) Café y cambio del paisaje en Colombia 1970-2005, Fondo Editorial Universidad EAFIT, Banco de la República, Medellín

Hamrick, J. L., Nason, J. D., Fleming, T. H. and Nassar, J. M. (2002) 'Genetic diversity in columnar cacti', in T. H. Fleming and A. Valiente-Banuet (eds) Columnar Cacti and their Mutualists: Evolution, Ecology, and Conservation, University of Arizona Press, Tucson, AZ, pp 122-133 Hargreaves, A. L., Harder, L. D. and Johnson, S. D. (2009) 'Consumptive emasculation: The ecological and evolutionary consequences of pollen theft', Biological Reviews, vol 84, pp259-276 
Helversen, O. V. (1993) 'Adaptations of flowers to the pollination by glossophagine bats', in W. Barthlott, C. M. Naumann, K. Schmidt-Loske and K. L. Schuchmann (eds) Animal-Plant Interaction in Tropical Environments, Museum Koenig, Bonn, Germany, pp41-59

Hoehn, P., Tscharntke, T., Tylianakis, J. M. and Steffan-Dewenter, I. (2008) 'Functional group diversity of bee pollinators increases crop yield', Proceedings of the Royal Society B: Biological Sciences, vol 275, pp2283-2291

Howell, D. J. and Roth, B. S. (1981) 'Sexual reproduction in Agaves: The benefits of bats; the costs of semelparous advertising', Ecology, vol 62, pp1-7 ICO (International Coffee Organization) (2009) International Coffee Organization Database, www.ico.org, last accessed October 2009 Irwin, R. E., Brody, A. K. and Waser, N. M. (2001) 'The impact of floral larceny on individuals, populations, and communities', Oecologia, vol 129, pp161-168

Kearns, C. A., Inouye, D. W. and Waser, N. M. (1998) 'Endangered mutualisms: The conservation of plant-pollinator interactions', Annual Review of Ecology and Systematics, vol 29, pp83112

Kevan, P. G. and Imperatriz-Fonseca, V. L. (2002) Pollinating Bees: The Conservation Link between Agriculture and Nature, Ministry of Environment, Brasília, Brazil

Klein, A.M. (2009) 'Nearby rainforest promotes coffee pollination by increasing spatio-temporal stability in bee species richness', Forest Ecology and Management, vol 258, pp1838-1845

Klein, A.M., Vaissière, B. E., Cane, J. H., Steffan-Dewenter, I., Cunningham, S. A., Kremen, C. and Tscharntke, T. (2007) 'Importance of pollinators in changing landscapes for world crops', Proceedings of the Royal Society B: Biological Sciences, vol 274, pp303-313

Klein, A.M., Cunningham, S. A., Bos, M. and Steffan-Dewenter, I. (2008a) 'Advances in pollination ecology from tropical plantation crops', Ecology, vol 89, pp935-943

Klein, A.M., Olschewski, R. and Kremen, C. (2008b) 'The ecosystem service controversy: Is there sufficient evidence for a "pollination paradox"?', GAIA, vol 17, pp12-16

Klein, A.M., Müller, C., Hoehn, P. and Kremen, C. (2009) 'Understanding the role of species richness for crop pollination services', in S. Naeem, D. E. Bunker, A. Hector, M. Loreau and C. Perrings (eds) Biodiversity, Ecosystem Functioning, and Human Wellbeing - an Ecological and Economic Perspective, Oxford University Press, Oxford, pp195-208

Koopman, K. F. (1981) 'The distributional patterns of New World nectar-feeding bats', Annals of the Missouri Botanical Gardens, vol 68, pp352-369

Kremen, C. (2008) 'Crop pollination services from wild bees', in R. R. James and T. L. Pitts-Singer (eds) Bee Pollination in Agricultural Ecosystems, Oxford University Press, US, pp10-26 
Kricher, J. (1999) A Neotropical Companion: An Introduction to the Animals, Plants, and Ecosystems of the New World Tropics, Princeton University Press, New Jersey

Lambin, E. F., Turner, B. L., Geist, H. J., Agbola, S. B., Angelsen, A., Bruce, J. W., Coomes, O. T., Dirzo, R., Fischer, G., Folke, C., George, P. S., Homewood, K., Imbernon, J., Leemans, R., Li, X., Moran, E. F., Mortimore, M., Ramakrishnan, P. S., Richards, J. F., Skanes, H., Steffen, W., Stone, G. D., Svedin, U., Veldkamp, T. A., Coleen, V. and Xu, J. (2001) 'The causes of land-use and land-cover change: Moving beyond the myths', Global Environmental Change, vol 11, pp261-269

Law, B. S. and Lean, M. (1999) 'Common blossom bats (Syconycteris australis) as pollinators in fragmented Australian tropical rainforest', Biological Conservation, vol 91, pp201-212

Manrique, A. J. and Thimann, R. E. (2002) 'Coffee (Coffea arabica) pollination with africanized honeybees in Venezuela', Interciencia, vol 27, pp414-416

Mayfield, M. M. (2005) 'The importance of nearby forest to known and potential pollinators of oil palm (Elaeis guineënsis Jacq.; Areceaceae) in southern Costa Rica', Economic Botany, vol 59, pp190-196

Mazvimavi, K. and Twomlow, S. (2009) 'Socioeconomic and institutional factors influencingadoption of conservation farming by vulnerable households in Zimbabwe',Agricultural Systems, vol 101, pp20-29

McGregor, S. E. (1976) Insect Pollination of Cultivated Crop Plants, US Department ofAgriculture, Washington, DC

Molina-Freaner, F. and Eguiarte, L. E. (2003) 'The pollination biology of two paniculate agaves (Agavaceae) from northwestern Mexico: Contrasting roles of bats as pollinators', American Journal of Botany, vol 90, pp1016-1024

Myers, N., Mittermeier, R. A., Mittermeier, C. G., da Fonseca, G. A. B. and Kent, J. (2000) 'Biodiversity hotspots for conservation priorities', Nature, vol 403, pp853-858

Muchhala, N. (2007) 'Adaptive trade-off in floral morphology mediates specialization for flowers pollinated by bats and hummingbirds', The American Naturalist, vol 169, pp494-504

Muchhala, N. and Thomson, J. D. (2010) 'Fur versus feathers: Pollen delivery by bats and hummingbirds, and consequences for pollen production', American Naturalist, vol 175, pp717-726

Nassar, J. M., Ramirez, N. and Linares, O. (1997) 'Comparative pollination biology of Venezuelan columnar cacti and the role of nectar-feeding bats in their sexual reproduction', American Journal of Botany, vol 84, pp918-927 
Nathan, P. T., Raghuram, H., Elangovan, V., Karuppudurai, T. and Marimuthu, G. (2005) 'Bat pollination of kapok tree, Ceiba pentandra', Current Science, vol 88,

pp1679-1681

Nyerges, A. E. and Green, G. M. (2000) 'The ethnography of landscape: GIS andremote sensing in the study of forest change in West African Guinea savanna',American Anthropologist, vol 102, pp271-289

Oldroyd, B. P. (2007) 'What's killing American honey bees?', PLoS Biol, vol 5, e168

Olschewski, R., Tscharntke, T., Benítez, P. C., Schwarze, S. and Klein, A. M. (2006) 'Economic evaluation of pollination services comparing coffee landscapes in Ecuador and Indonesia', Ecology and Society, vol 11, p7

Olschewski, R., Klein, A.M. and Tscharntke, T. (2010) 'Economic trade-offs between carbon sequestration, timber production, and crop pollination in tropical forested landscapes', Ecological Complexity, vol 7, pp314-319

Ortega-Olivencia, A., Rodriguez-Riano, T., Valtuena, F. J., Lopez, J. and Devesa, J. A. (2005) 'First confirmation of a native bird-pollinated plant in Europe', Oikos, vol 110, pp578-590

Ricketts, T. H. (2004) 'Tropical forest fragments enhance pollinator activity in nearby coffee crops', Conservation Biology, vol 18, pp1262-1271

Ricketts, T. H., Daily, G. C., Ehrlich, P. R. and Michener, C. D. (2004) 'Economic value of tropical forest to coffee production', Proceedings of the National Academy of Sciences of the United States of America, vol 101, pp12579-12582

Ricketts, T. H., Regetz, J., Steffan-Dewenter, I., Cunningham, S. A., Kremen, C., Bogdanski, A., Gemmill-Herren, B., Greenleaf, S. S., Klein, A. M., Mayfield, M. M., Morandin, L. A., Ochieng, A. and Viana, B. F. (2008) 'Landscape effects on crop pollination services: Are there general patterns?', Ecology Letters, vol 11, pp499-515

Roesel, C. S., Kress, W. J. and Bowditch, B. M. (1996) 'Low levels of genetic variation in Phenakospermum guyannense (Strelitziaceae), a widespread bat-pollinated

Amazonian herb', Plant Systematics and Evolution, vol 199, pp1-15

Roubik, D. W. (1995) Pollination of Cultivated Plants in the Tropics, Food and Agriculture Organization of the United Nations, Bulletin 118, Rome, Italy

Roubik, D. W. (2002a) 'Feral African bees augment Neotropical coffee yield', in P.

Kevan and V. L. Fonseca (eds) Pollinating Bees: The Conservation Link between Agriculture and Nature, Ministry of Environment, Brazil

Roubik, D. W. (2002b) 'The value of bees to the coffee harvest', Nature, vol 417, p708 
Roubik, D. W. (2009) 'Ecological impact on native bees by the invasive Africanized honey bee', Acta Biológica Colombiana, vol 14, pp115-124

Slaa, E. J., Sánchez Chaves, L. A., Malagodi-Braga, K. S. and Hofstede, F. E. (2006) 'Stingless bees in applied pollination: Practice and perspectives', Apidologie, vol 37, pp293-315

Steffan-Dewenter, I., Münzenberg, U., Bürger, C., Thies, C. and Tscharntke, T. (2002) 'Scaledependent effects of landscape context on three pollinator guilds', Ecology, vol 83, pp14211432

Thomson, J. D. (2003) 'When is it mutualism?', American Naturalist, vol 162, ppS1-S9

Tscharntke, T., Klein, A. M., Kruess, A., Steffan-Dewenter, I. and Thies, C. (2005) 'Landscape perspectives on agricultural intensification and biodiversity-ecosystem service management', Ecology Letters, vol 8, pp857-874

Valiente-Banuet, A., Santos, R., Arizmendi, M. D. and Casas, A. (2007) 'Pollination biology of the hemiepiphytic cactus Hylocereus undatus in the Tehuacan Valley,Mexico', Journal of Arid Environments, vol 68, pp1-8

Veddeler, D., Klein, A. M. and Tscharntke, T. (2006) 'Contrasting responses of beecommunities to coffee flowering at different spatial scales', Oikos, vol 112,pp594-601

Veddeler, D., Olschewski, R., Tscharntke, T. and Klein, A. M. (2008) 'The contributionof nonmanaged social bees to coffee production: New economic insights based onfarm-scale yield data’, Agroforestry Systems, vol 73, pp109-114

Vergara, C. H. and Badano, E. I. (2009) 'Pollinator diversity increases fruit productionin Mexican coffee plantations: The importance of rustic management systems',Agriculture, Ecosystems \& Environment, vol 129, pp117-123

Villalobos, S., Vargas, O. and Melo, S. (2007) 'Uso, manejo y conservación de 'yosú', Stenocereus griseus (Cactaceae) en la Alta Guajira colombiana', Acta Biologica Colombiana, vol 12, pp99-112

Vogel, S. (1969) 'Chiropterophilie in der neotropischen flora, neue mitteilungen II', Flora, vol 158, pp185-222

Wesselingh, R. A. (2007) 'Pollen limitation meets resource allocation: Towards a comprehensive methodology', New Phytologist, vol 174, pp26-37

Williams, I. H. (1994) 'The dependences of crop production within the European Union on pollination by honey bees', Agricultural Science Reviews, vol 6, pp229-257

Winfree, R., Griswold, T. and Kremen, C. (2007) 'Effect of human disturbance on bee communities in a forested ecosystem', Conservation Biology, vol 21, pp213-223 
Winfree, R., Williams, N. M., Gaines, H., Ascher, J. S. and Kremen, C. (2008) 'Wild bee pollinators provide the majority of crop visitation across land-use gradients in New Jersey and Pennsylvania, USA’, Journal of Applied Ecology, vol 45, pp793-802

Winter, Y. and Helversen, O. V. (2003) 'Operational tongue length in phyllostomid nectar-feeding bats', Journal of Mammalogy, vol 84, pp886-896

Wunder, S. (2000) The Economic of Deforestation: The Example of Ecuador, MacMillan Press Ltd, Hampshire, UK

Young, A. M. (1994) The Chocolate Tree, Smithsonian Institution Press, Washington, DC 


\section{ACKNOWLEDGMENTS}

First of all I want to thank my supervisors Teja Tscharntke and Alexandra-Maria Klein for supporting me in the development and funding of my own project from scratch, for the opportunity to go to Indonesia for my research, and for their guidance and support during the entire time. I am grateful for their ability of creating a warm and familiar working atmosphere. I am greatly indebted to Thomas Wanger, who has supported my work from the start to the end and gave most valuable advice and hands-on help in the field. Thank you for reading and commenting all my manuscript versions also in late office hours and on the weekends.

I want to especially acknowledge Navjot Sodhi, who sadly passed away in 2011. He supported my work during the first year and working with him was wonderful.

I am deeply grateful to my team in Indonesia, especially Abhe, Sisi, Soni, Wandi, Anki, Salo, Man, Yesni and Nel and to everyone I had the pleasure to work with, but also my housemate Edi, for their assistance not only in establishing and conducting the experiments, but also for their kind spirits, sense of humor and friendship making my time in Indonesia an invaluable experience! This was certainly one of the best times I had during my $\mathrm{PhD}$ and you will always have a special place in my heart. This is also in remembrance of Oma (Ibu Dorte) who let us live in her house even though our behavior as foreign researchers must have seemed strange. I thank Anty, Pak Shahabuddin, Iby Aiyen, and Pak Rauf from the Tadulako University and Wolfram Lorenz and Dewi for administrative help and many other tasks throughout my research, the people at RISTEK and LIPI for issuing the research and export permits, and all the owners of my study sites, village heads and villagers in the study region for their hospitality and kind cooperation. Thanks also to colleagues and friends Arno, Pierre, and the ELUC team for the great time in Sulawesi.

I am also very grateful to my friends and dear colleagues for their help, scientific and nonscientific discussions, for patiently answering my questions, advices, for proofreading and a good working atmosphere. Thank you also for your friendship, for many nice conversations, for eating lunch together, climbing and partying with me, especially to my office mates Chrissi, Georg, William, and Björn, and my colleagues Verena, Claudia, Hella, Carmen, Kevin, and basically everyone else from the group. Sincere gratitude goes to Urs for his patience with answering my statistics questions and for helping me to calm down with yoga and climbing and for being there for me not only during the last stages of the PhD. for being m extremely grateful to Yann Clough and Christoph Scherber for their help with statistics and friendly support. Particular thanks to Jutta Gilles who was extremely helpful with all administrative matters, especially with the very annoying 
process of getting refunds.

I kindly thank the co-authors on my manuscripts, especially Lucas Alejandro Garibaldi, Nathan Muchhala, Liliana Bravo-Monroy, and Roland Olschewski. I highly acknowledge Stephan Risch and Ivone for help with insect identification. Thanks to Gretchen Daily and her team for giving me the opportunity to experience science at Stanford and for additional funds. Financial support was kindly provided by the DAAD and DFG.

Finally and most importantly I want to thank my family and friends with all my heart for loving me and for encouraging and supporting me during all times. 


\section{Curriculum Vitae}

\section{Personal Record}

Name:

Address:

Date / Place of birth:
Iris Motzke

Von-Ossietzky-Str. 5a

37085 Göttingen

07th of November, 1981 / Boeblingen,

Germany

\section{Education}

2001

in

$2002-2008$

2005

Oct. 2009 -Mai 2014
„Abitur"(final secondary school examination) - Wildermuth-Gymnasium Tübingen, Germany.

Biology Diploma (equivalent to Master of Science degree) - University of Tübingen, Germany Internship at the University of Western Australia, Perth, Australia

\section{SCHOLARSHIPS AND RESEARCH GRANTS}

2005

2007

2010-2011

2011

$2012-2015$
Baden Württemberg Scholarship „travel costs“

Baden Württemberg Scholarship for student abroad

DAAD PhD Scholarship

Research Grant (Internationalisation University Göttingen) at the Stanford University, California

DFG grant (PhD-Position)

\section{Practical Training, Research Projects}

Feb. - April 2006

Aug. - Dec. 2006

Dec. 2006 - April 2007

May - Aug 2008
Methodological testing at Zoo Zurich, Switzerland

Volunteer work and diploma thesis at the Angkor Centre for Conservation of Biodiversity in Cambodia

Ecotoxicological research at the Faculty of Biological Sciences, University of the Philippines, Manila, Philippines.

Scientific assistant: Herpetological biodiversity assessments in 
Sulawesi. University of Göttingen, Germany and the University of Adelaide, Australia

Sept- Dec. 2008

Voluntary field work on reptiles and marsupials in South Australia.

May - Oct 2009

Scientific assistant: Toad-Mosquito interactions in Sulawesi,

University of Göttingen, Germany, and the University of Adelaide,

Australia

\section{LANGUAGES}

English (fluent), French (basic knowledge), Indonesian (basic knowledge) 


\section{Publications}

I Motzke, Klein AM, Shahabuddin S, Wanger TC, Tscharntke T (in prep.): Crop yield in tropical homegardens needs bee management on three spatial scales.

I Motzke,Tscharntke T, Wanger TC, Klein AM (2015): Pollination mitigates cucumber yield gaps more than pesticide and fertilizer use in tropical smallholder gardens. Journal of Applied Ecology, 52: 261-269.

L Garibaldi, Steffan-Dewenter I, Winfree R, Aizen M, Bommarco R, Cunningham S, Kremen C, Carvalheiro L, Harder L, Afik O, Bartomeus I, Benjamin F, Boreux V, Cariveau D, Chacoff N, Dudenhöffer J, Freitas B, Ghazoul J, Greenleaf S, Hipólito J, Holzschuh A, Howlett B, Isaacs R, Javorek S, Kennedy C, Krewenka K, Krishnan S, Mandelik Y, Mayfield M, Motzke I, Munyuli T, Nault B, Otieno M, Petersen J, Pisanty G, Potts S, Rader R, Ricketts T, Rundlöf M, Seymour C, Schüepp C, Szentgyörgyi H, Taki H, Tscharntke T, Vergara C, Viana B, Wanger TC, Westphal C, Williams N, Klein A (2013): Wild pollinators enhance fruitset of crops worldwide, regardless of honey bee abundance.. Science, 339, 1608-1611.

I Motzke, Tscharntke T, Sodhi NS, Klein AM, Wanger TC (2013): Ant seed predation, pesticide applications and farmers' income from tropical multi-cropping gardens. Agricultural and Forest Entomology 15, 245-254.

I Motzke, Wanger TC, Guth E, Tscharntke T, Barkmann J (2012): Socio-economic context of biodiversity use and conservation along a town-forest gradient in Cambodia. Raffles Bulletin of Zoology, 25: 29-45.

T Tscharntke, Clough C, Jackson L, Motzke I, Perfecto I, Vandermeer J, Wanger TC, Whitbread A (2012): Global food security, biodiversity conservation, and the future of agricultural intensification. Biological Conservation 151: 53-59.

TC Wanger, Wielgoss AC, Motzke I, Clough Y, Brook BW, Sodhi NS, Tscharntke T (2011): Endemic predators, invasive prey, and native diversity. Proceedings of the Royal Society B, 278: 690-694.

TC Wanger, Motzke I, Shahabuddin S, Iskandar DT (2011): Amphibians and reptiles of Lore Lindu National Park, Sulawesi (Indonesia). Salamandra 47: 17-29.

TC Wanger, Iskandar DT, Motzke I, Brook BW, Sodhi NS, Clough Y, Tscharntke T (2010): Landuse change affects community composition and traits of tropical amphibians and reptiles in Sulawesi (Indonesia). Conservation Biology, 24: 795-802. 
TC Wanger, Motzke I, Furrer SC, Brook BW, Gruber B (2009): How to monitor elusive lizards: comparison of capture-recapture methods on giant day geckos (Gekkonidae, Phelsuma madagascariensis grandis) in the Masoala rainforest exhibit, Zurich Zoo. Ecological Research. $24(2) ; 345-353$.

TC Wanger, Motzke I, Furrer SC, Gruber B (2009): Spatial distribution and habitat preferences of the giant day gecko (Phelsuma madagascariensis grandis) in the Masoala rainforest exhibit, Zoo Zurich. Salamandra. 45(3); 15p.

TC Wanger, Motzke I, Rödel M-O (2006): Zur Entwicklung der Diversität der Herpetofauna des östlichen Landschaftsschutzgebietes Spitzberg bei Tübingen am Neckar. - Jahreshefte Gesellschaft für Naturkundliche Mitteilungen Württemberg 162: 283-294

\section{BOOK CONTRIBUTIONS}

Garibaldi LA, Muchhala N, Motzke I, Bravo-Monroy L, Olschewski R, Klein AM (2011): Services from plant-pollinator interactions in the Neotropics. En: Ecosystem services from agriculture and agroforestry: measurement and payment (eds. Rapidel B, DeClerck F., Le Coq J.F. y Beer J.). Earthscan, London, UK, pages. 119-139. 